\title{
Recreating the 1950's Chesapeake Bay: Use of a Network Model to Guide the Application of a Eutrophication Model
}

Dorothy H. Tillman and Carl F. Cerco

August 2009

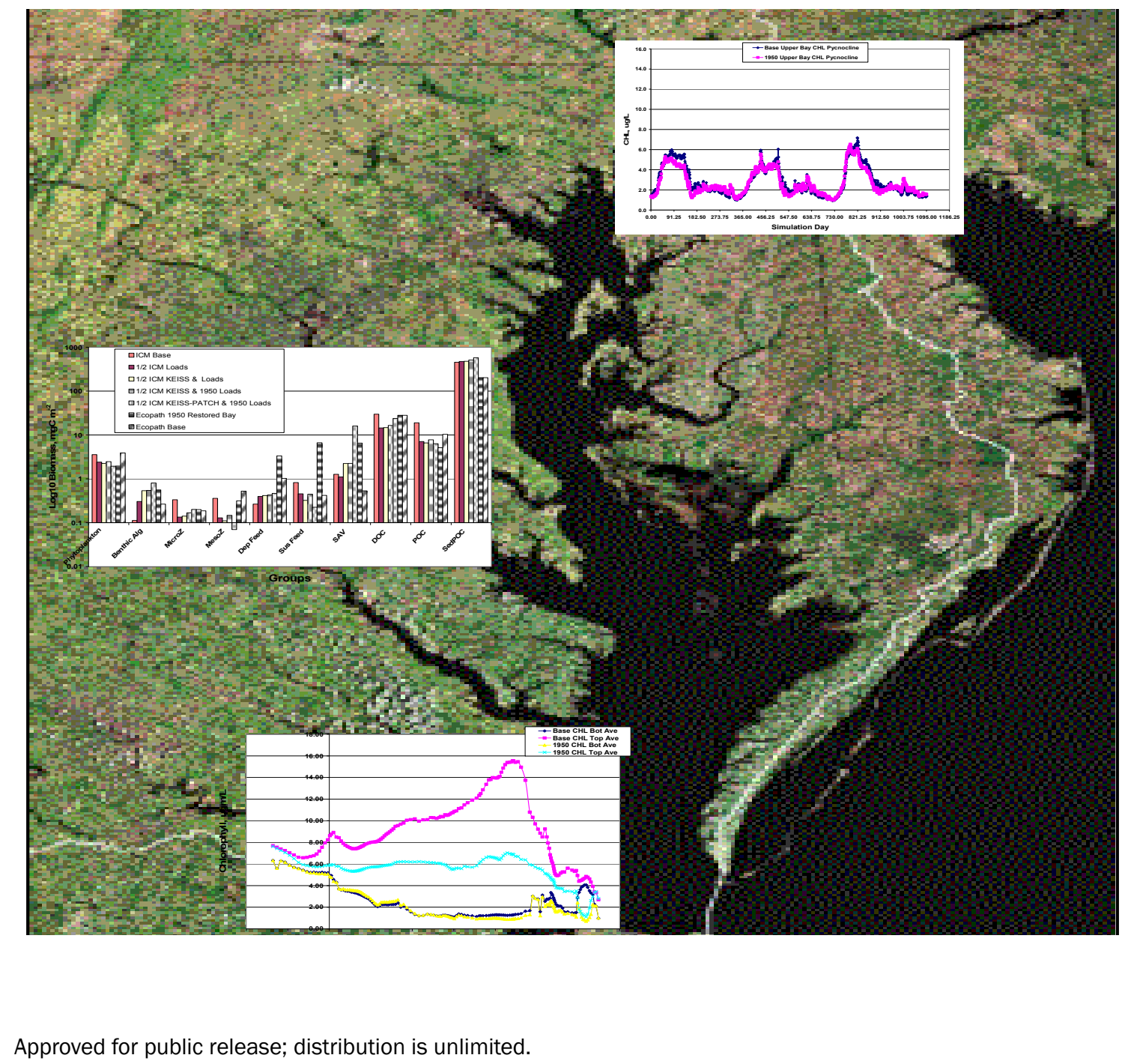




\section{Recreating the 1950's Chesapeake Bay: Use of a Network Model to Guide the Application of a Eutrophication Model}

Dorothy H. Tillman and Carl F. Cerco

Environmental Laboratory

U.S. Army Engineer Research and Development Center

3909 Halls Ferry Rd.

Vicksburg, MS 39180-6199

Final report

Approved for public release; distribution is unlimited.

Prepared for U.S. Army Corps of Engineers

Washington, DC 20314-1000

Under Work Unit 33143 


\begin{abstract}
This report is the last of a series that documents research relating the coupling of spatially and temporally detailed eutrophication models with ecosystem models that lack spatial and temporal resolution. Specifically, the Corps of Engineers Integrated Compartment Water Quality Model, CE-QUAL-ICM (ICM) is coupled to the Ecopath with Ecosim (EWE) fisheries model.
\end{abstract}

This research examines the feasibility of restoring the ecosystem that existed in the 1950s mid Bay based on current knowledge of the driving forces of overabundance of nutrients and decreased water clarity. Making adjustments to loads and coefficients controlling eutrophication through a numerical water quality model is one way to study this problem. Five simulations using the 2002 CBEM were conducted with analyses only discussed for the mid Bay. All model runs were simulated for the same time period, 1985 through 1994 , but only analyzed for the 1985 through 1987 period. ICM produced reasonable results for conditions that could have occurred in the 1950s. Although observed data were scarce from the 1950 or 1960 's to make comparisons, the results follow behavior described in literature by other researchers. These runs demonstrate the ability of ICM to reasonably predict past or future conditions of a system.

DISCLAIMER: The contents of this report are not to be used for advertising, publication, or promotional purposes. Citation of trade names does not constitute an official endorsement or approval of the use of such commercial products. All product names and trademarks cited are the property of their respective owners. The findings of this report are not to be construed as an official Department of the Army position unless so designated by other authorized documents. 


\section{Contents}

Figures and Tables................................................................................................................

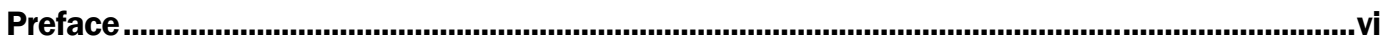

Unit Conversion Factors..........................................................................................................................vii

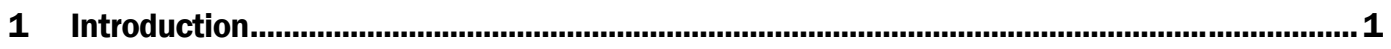

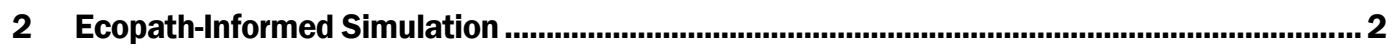

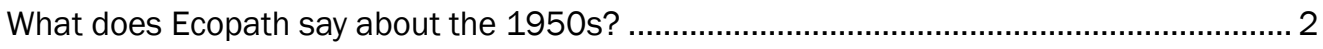

Comparison of basic input of modern mid Bay to 1950s mid Bay...................................... 2

Primary producers........................................................................................................... 4

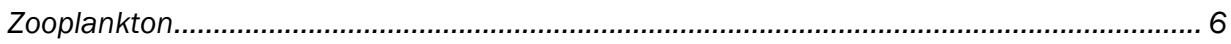

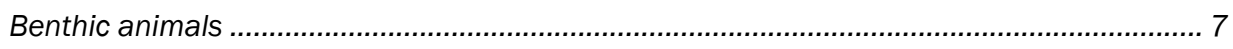

Fish

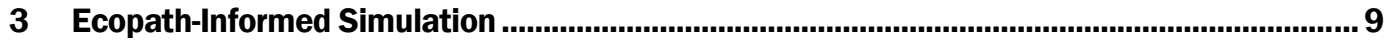

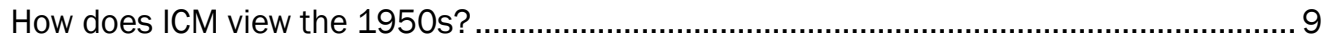

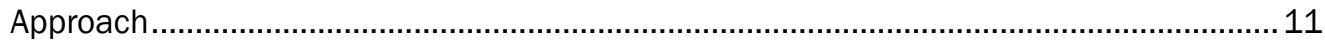

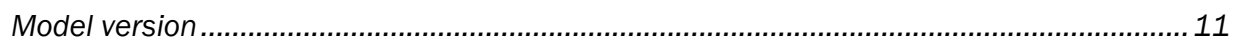

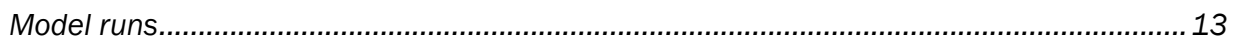

Sensitivity results presentation ........................................................................... 17

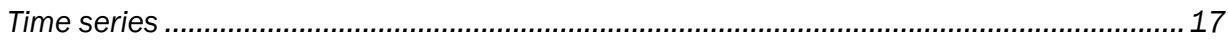

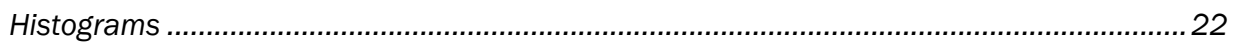

1950s restored mid Bay result presentation ................................................................ 24

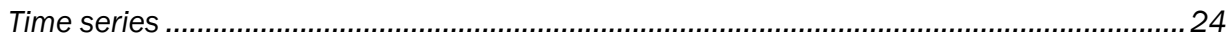

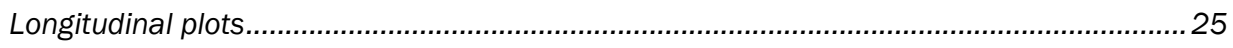

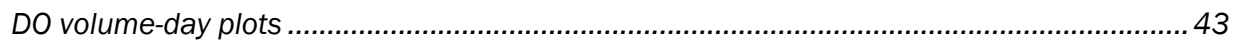

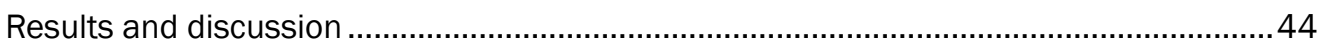

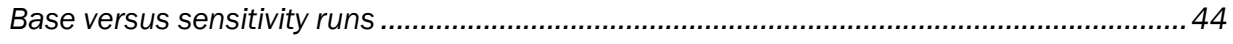

Base versus 1950's restored mid Bay run .............................................................. 53

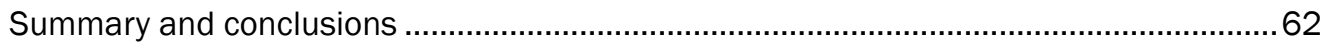

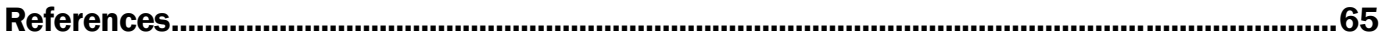

\section{Report Documentation Page}




\section{Figures and Tables}

\section{Figures}

Figure 1. Physical and computational grid of the 13000 cell Chesapeake Bay model.

Figure 2. Chesapeake Bay Program Segments.................................................................................... 16

Figure 3. Phytoplankton limitation results for base, SR1, and SR2 in the mid Chesapeake Bay.

Figure 4. Microphytobenthic algae limitation results for base, SR1, and SR2 for the mid Chesapeake Bay

Figure 5. SAV limitation results for base, SR1, and SR2 in the mid Chesapeake Bay. .................... 21

Figure 6. Comparison of biomasses for each group common to ICM and Ecopath..........................22

Figure 7. Comparison of ICM and Ecopath P/B ratios................................................................23

Figure 8. Comparison of ICM and Ecopath Q/B ratios. ..................................................................23

Figure 9. Comparison of UA/Q ratios from ICM to values used in Ecopath..................................... 24

Figure 10. Comparison of surface Chlorophyll a for base and 1950s RMB2 results in the upper, mid, and lower regions of the Chesapeake Bay.

Figure 11. Comparison of surface DO for base and 1950's RMB2 results in the upper, $\mathrm{mid}$, and lower regions of the Chesapeake Bay.

Figure 12. Comparison of surface TN for base and 1950's RMB2 results in the upper, mid, and lower regions of the Chesapeake Bay.

Figure 13. Comparison of surface TP for base and 1950's RMB2 results in the upper, mid, and lower regions of the Chesapeake Bay.

Figure 14. Comparison of surface light extinction for base and 1950's RMB2 results in the upper, mid, and lower regions of the Chesapeake Bay.

Figure 15. Comparison of the pycnocline Chlorophyll a for base and 1950's RMB2 results in the upper, mid, and lower regions of the Chesapeake Bay.

Figure 16. Comparison of the pycnocline DO for base and 1950's RMB2 results in the upper, mid, and lower regions of the Chesapeake Bay.

Figure 17. Comparison of the pycnocline TN for base and 1950's RMB2 results in the upper, mid, and lower regions of the Chesapeake Bay.

Figure 18. Comparison of the pycnocline TP for base and 1950's RMB2 results in the upper, mid, and lower regions of the Chesapeake Bay.

Figure 19. Comparison of the deep chlorophyll a for base and 1950's RMB2 results in the upper, mid, and lower regions of the Chesapeake Bay.

Figure 20. Comparison of the deep DO for base and 1950's RMB2 results in the upper, mid, and lower regions of the Chesapeake Bay.

Figure 21. Comparison of the deep TN for base and 1950's RMB2 results in the upper, mid, and lower regions of the Chesapeake Bay.....

Figure 22. Comparison of the deep TP for base and 1950's RMB2 results in the upper, mid, and lower regions of the Chesapeake Bay... 
Figure 23. Areal concentrations of chlorophyll a for the upper Chesapeake Bay for base and 1950s RMB2.

Figure 24. Areal concentrations of chlorophyll a for the mid Chesapeake Bay for base and 1950's RMB2.

Figure 25. Areal concentrations of chlorophyll a for the lower Chesapeake Bay for base and 1950s RMB2.

Figure 26. Comparison of summer averaged (1985-1987) chlorophyll a results longitudinally from the Susquehanna River $(\approx 325 \mathrm{~km})$ to the open ocean $(\approx-70 \mathrm{~km})$.

Figure 27. Comparison of summer averaged (1985-1987) DO results longitudinally from the Susquehanna River $(\approx 325 \mathrm{~km})$ to the open ocean $(\approx-70 \mathrm{~km})$.

Figure 28. Comparison of summer averaged (1985-1987) TN results longitudinally from the Susquehanna River $(\approx 325 \mathrm{~km})$ to the open ocean $(\approx-70 \mathrm{~km})$.

Figure 29. Comparison of summer averaged (1985-1987) TP results longitudinally from the Susquehanna River $(\approx 325 \mathrm{~km})$ to the open ocean $(\approx-70 \mathrm{~km})$.

Figure 30. Comparison of summer averaged (1985-1987) light extinction results longitudinally from the Susquehanna River $(\approx 325 \mathrm{~km})$ to the open ocean $(\approx-70 \mathrm{~km})$.

Figure 31. Three regions of Chesapeake Bay.

Figure 32. DO volume day for mid Chesapeake Bay region DO $\leq$ 0.1., 1.0, 2.0, and 5.0................. 45

Figure 33. DO volume day for upper Chesapeake Bay region for $\mathrm{DO} \leq 0.1 ., 1.0,2.0$, and 5.0.

Figure 34. DO volume day for lower Chesapeake Bay region DO $\leq 0.1 ., 1.0,2.0$, and 5.0.............. 47

Figure 35. Secchi depth measurements in upper Chesapeake Bay region at segments $\mathrm{CB} 1, \mathrm{CB} 2$, and $\mathrm{CB} 3$.

Figure 36. Secchi depth measurements in the mid Chesapeake Bay region at segments CB4, and CB5.

Figure 37. Secchi depth measurements in the lower Chesapeake Bay region at segments $\mathrm{CB} 6, \mathrm{CB} 7$ and $\mathrm{CB} 8$.

Figure 38. Hectares of submerged aquatic vegetation in Chesapeake Bay Program Segment CB1 1978-2006.

Figure 39. ICM normalized DO volume water at three intervals: upper - DO $\leq 0.1$, middle $\mathrm{DO} \leq 1.0$, and lower $-\mathrm{DO} \leq 2.0$.

Figure 40. ICM normalized DO volume water at three intervals: upper - DO $\leq 0.1$, middle $\mathrm{D} 0 \leq 1.0$, and lower $-\mathrm{DO} \leq 2.0$.

\section{Tables}

Table 1. Comparison of biomass and production rates Hagy (2002) used for the mid modern Bay (base) and 1950 restored Bay runs. 


\section{Preface}

This work was conducted under funding from the System-Wide Water Resources Program (SWWRP). Dr. Steven L. Ashby is Program Manager of SWWRP. The work was conducted under the direct supervision of Dr. Barry W. Bunch, Chief, Water Quality and Contaminant Modeling Branch, Environmental Laboratory (EL), U.S. Army Engineer Research and Development Center (ERDC), Vicksburg, MS.

This report was prepared by Dorothy H. Tillman and Carl F. Cerco of the Water Quality and Contaminant Modeling Branch, EL, ERDC. At the time of publication of this report, Dr. Beth Fleming was Director of EL.

COL Gary E. Johnston was Commander and Executive Director of ERDC. Dr. James R. Houston was Director. 


\section{Unit Conversion Factors}

Multiply

square miles
By

$2.589998 \mathrm{E}+06$
To Obtain

square meters 


\section{Introduction}

The present report is the last of a series that documents research relating the coupling of spatially and temporally detailed eutrophication models with ecosystem models that lack spatial and temporal resolution. Specifically, the Corps of Engineers Integrated Compartment Water Quality Model (CE-QUAL-ICM, Cerco and Meyers 2000) is coupled to the Ecopath with Ecosim (EWE) fisheries model (Christensen et al. 2000). Previous reports in this series introduced the concepts necessary for communication between the two models (Tillman et al. 2006), detailed the linkage (Cerco and Tillman 2008), and documented a graphical interface created to facilitate information exchange between the two models (Cerco et al. 2008).

Information can be exchanged between the two models via multiple pathways. Previous efforts have concentrated on determining common quantities computed in both models and on exchanging precise numerical values. A different form of information exchange uses a calibrated EWE application to guide the development of a similar ICM application. Guiding ICM with EWE can be especially useful in view of the multiple pathways for cycling of carbon, nutrients, dissolved oxygen, and other substances in ICM. Although ICM is commonly calibrated to match observations of biomass, concentration, and similar stocks, the connections and mass fluxes between modeled organisms, trophic levels, and communities are less readily validated. The strength of EWE is in the rigorous computation of flows between organisms and trophic levels. Consequently, EWE modeled fluxes can be compared to ICM and used to guide the valuation of ICM parameters and fluxes.

In the present report, EWE is used to examine and guide an ICM application that extends outside the range of ICM model validation. Specifically, an ICM model of Chesapeake Bay 1985-1994 is used to simulate Chesapeake Bay circa 1950, a period in which nutrient loads were roughly half their present values. Nutrient loads, light attenuation, and submerged aquatic vegetation abundance are varied in order to achieve agreement between ICM and the EWE simulation of the 1950s Chesapeake Bay. 


\section{Ecopath-Informed Simulation}

\section{What does Ecopath say about the 1950s?}

Of all the estuaries of the continental United States of America, the Chesapeake Bay is by far the largest with over 4,479 square (sq) miles of surface area encompassing the bay and its major tributaries. Since the 1950 , regular water quality monitoring has been conducted on the Bay to help identify causes of anthropogenic induced eutrophication and anoxia (Bratton et al. 2003). Before the 1950s, most data describing the conditions in the Chesapeake Bay were from historical descriptive observations (Hagy 2002).

To explore the resources of the mid Chesapeake Bay in the 1950s and relate them to the modern mid Bay, Hagy (2002) developed a Bay network model using data or relationships from literature and historical data to parameterize 1950 s conditions during the summer period of June through August. The idea was to show that secondary production (biomass produced by heterotrophic organisms) could be maintained with higher trophic transfer efficiency even though primary production was reduced. Hagy (2002) developed a series of rules and assumptions based on cited literature to keep values when setting parameters for different groups representing the 1950 as real as possible. Of the 34 groups originally modeled to represent the modern mid Bay network, biomass and production rates of 17 of these groups were adjusted to values believed to be what had or might have occurred in the 1950s. Other parameters related to these were adjusted accordingly. Table 1 compares 1950 s values of parameters modified (i.e., biomass, production and consumption rates, etc.) to modern mid Bay values for these groups for the two Ecopath runs (Hagy 2002).

\section{Comparison of basic input of modern mid Bay to 1950s mid Bay}

As long as a 100 years ago, signs of over-enrichment of nutrients (eutrophication) and decreased water clarity were noted in the Chesapeake Bay from sediment core samples (Kemp et al. 2005; Cooper and Brush 1993; Nielsen et al. 2002). An overabundance of nutrients resulting in eutrophication is complemented by higher primary productivity (Paerl et al. 2006; Scavia et al. 2006: and Jaworski et al. 1992) which has been 
Table 1. Comparison of biomass and production rates Hagy (2002) used for the mid modern Bay (base) and 1950 restored Bay runs.

\begin{tabular}{|c|c|c|c|c|}
\hline Group & $\begin{array}{l}\text { 1950s } \\
\text { Biomass } \\
\mathrm{mgC} / \mathrm{m}^{2}\end{array}$ & $\begin{array}{l}\text { Base } \\
\text { Biomass } \\
\mathrm{mgC} / \mathrm{m}^{2}\end{array}$ & $\begin{array}{l}1950 s \\
\text { Production } \\
\mathrm{mgC} / \mathrm{m}^{2} / \text { day }\end{array}$ & $\begin{array}{l}\text { Base } \\
\text { Production } \\
\mathrm{mgC} / \mathrm{m}^{2} / \text { day }\end{array}$ \\
\hline Net Phytoplankton & 1663 & 3326 & 981 & 1962 \\
\hline Picoplankton & 294 & 587 & 256 & 511 \\
\hline Free Bacteria & 503 & 2415 & 568 & 1425 \\
\hline Particle Attached Bacteria & 37 & 73 & 42 & 82 \\
\hline Heteroflagellates & 55 & 149 & 154 & 417 \\
\hline Ciliates & 57 & 147 & 142 & 366 \\
\hline Meroplankton & 120 & 18 & 60 & 9 \\
\hline Mesozooplankton & 316 & 526 & 158 & 263 \\
\hline Microphytobenthos & 559 & 265 & 335 & 159 \\
\hline $\begin{array}{l}\text { Submerged Aquatic } \\
\text { Vegetation }\end{array}$ & 13500 & 1952 & 122 & 18 \\
\hline Benthic Bacteria & 163 & 298 & 184 & 337 \\
\hline Meiofauna & 700 & 494 & 49 & 35 \\
\hline Deposit Feeders & 3333 & 1030 & 47 & 14 \\
\hline Suspension Feeders & 6666 & 421 & 93 & 6 \\
\hline Menhaden & 2176 & 2136 & 54 & 53 \\
\hline Spot & 316 & 222 & 3.2 & 2.2 \\
\hline Croaker & 322 & 226 & 3.2 & 2.3 \\
\hline
\end{tabular}


linked to anoxic and hypoxic conditions in the Bay (Taft et al. 1980; Officer et al. 1984). In the 1950s there were short periods of seasonal low dissolved oxygen waters, but these periods were short compared to what occurs now (Officer et al. 1984). Episodic anoxia and hypoxia have increased in duration and extent in the bottom waters of the Bay (Cooper and Brush 1993; Kemp et al. 1992). As a result of these events, distinct changes to many plant and animal communities have occurred over the past 50 years or more in the Chesapeake Bay (Kemp et al. 2005). With this in mind, parameters used in developing network models for conditions representing summer conditions in the mid Bay in the 1950 os can be compared to the present.

\section{Primary producers}

To reconstruct group parameters for the 1950s model, Hagy (2002) began with the primary producers and set their basic input parameters to what would have occurred in a restored Bay. Hagy began by adjusting values of submerged aquatic vegetation(SAV) biomass and production rates. SAV are of great importance to the Chesapeake Bay because they provide a vital link in the food web. Not only are they a source of food for waterfowl but they also provide habitat and spawning grounds for many fish species (Davis 1985). Since the composition of communities and abundance of the groups were so different in the 1950s than modern day, this group would have provided a greater contribution to total primary production. Changes in SAV communities (especially SAV biomass and production) have been linked to storm damage, human-induced eutrophication, increased turbidity, and increased light attenuation/reduced water clarity that is cited as major causes pointing to their decline (Orth and Moore 1984; Bayley et al. 1978; Brush et al. 1980). Increased light attenuation from reduced water clarity has been singled out as one of the main contributors to reduced SAV coverage (Carter and Rybicki 1986, 1990). Considering this, Hagy (2002) set SAV biomass and production rate accordingly. SAV biomass and production rates were assumed to be seven times greater than modern mid Bay values. Hagy's reasoning was based on aerial and historical observations (Orth and Moore 1986). From these photographs it was inferred that SAV coverage possibly grew in waters up to $2 \mathrm{~m}$ depth. Dennison et al. (1993) found that SAV growth in the Chesapeake Bay was restricted to waters less than $3 \mathrm{~m}$ (at mean low water, MLW) representing about 10 percent of the bottom surface area of the Bay (Cronin and Pritchard 1975). This translates to a sevenfold increase of the mid Bay's area containing SAV coverage when compared to present day SAV 
coverage. Thus, SAV biomass value was set to approximately $13500 \mathrm{mgC} / \mathrm{m}^{2}$ as compared to $1952 \mathrm{mgC} / \mathrm{m}^{2}$ (Batiuk et al. 1992). SAV modified parameters are shown in Table 1 for the 1950s and modern mid Bay estimates.

Continuing with primary producers, phytoplankton parameters were adjusted. Historical data have shown phytoplankton dynamics changed significantly: 1) increased nutrients have doubled phytoplankton biomass since the 1950 (U.S. Environmental Protection Agency (USEPA) 1983; Harding 1994; Harding et al. 2002; Harding and Perry 1997); 2) present plankton community size is dominated by picoplankton and nanoplankton since the 1950s (Malone et al. 1991; Verity 1988; Harding 1994); and 3) species composition consists of more flagellated species than centric diatoms (Marshall and Lacouture 1986). Previous to World War II very little or no water quality data including chlorophyll $a$ data had been collected (Harding and Perry 1997). Even when collected, spatial and temporal data were sparse compared to monitoring locations and frequency in later years (Harding 1994). In Harding and Perry (1997), chlorophyll $a$ values are shown to have increased from an average of approximately $3.7 \mathrm{mg} / \mathrm{m}^{3}$ in the $1950 \mathrm{Os}$ to $9.0 \mathrm{mg} / \mathrm{m}^{3}$ in the $1980 \mathrm{~s} / 1990 \mathrm{os}$ the mid Bay. Consequently, as initial starting values for net phytoplankton and picoplankton groups, Hagy (2002) halved the modern mid Bay values of biomass and production rate (Table 1).

In the shallow-water bottom of the Chesapeake Bay, microphytobenthos (microscopic, photosynthetic eukaryotic algae and cyanobacteria) were believed to be more abundant during the 1950 os than present day (Kemp et al. 2005). Under this assumption, Hagy (2002) considered production of microphytobenthos a function of the Bay bathymetry and light penetration. With greater light penetration, more bottom area was available to support a greater microphytobenthos community increasing primary production (MacIntyre et al. 1996). Daily production in the mid modern Bay was calculated as $\sum A_{z} P_{\max } \operatorname{TANH}\left(I_{z} / E_{k}\right)$ where $A_{z}$ is the sediment area within 1-m depth intervals and $I_{Z}=I_{o} e^{-k_{d}^{z}}$ (Hagy 2002). $P_{\max }$ (gross production rate) was assumed not to vary with depth. For the 1950 model, microphytobenthos production was recalculated with $\mathrm{k}_{\mathrm{d}}$ set to 0.4 and the sediment area estimated to the 2-m depth. Values for biomass and production rate for the 1950 os model were set to slightly more 
than double what they were set to for the present-day model. Values used were $559 \mathrm{mgC} / \mathrm{m}^{2}$ and $335 \mathrm{mgC} / \mathrm{m}^{2} /$ day, respectively.

Other members of the plankton community (e.g., bacteria, microzooplankton, mesozooplankton, meropankton, ctenophores, and sea nettles) have been affected by eutrophication and anoxia/hypoxia as well since the 1950s. Estimating the parameters for the 1950s restored Bay model, Hagy (2002) assumed bacterial growth efficiency (BGE=Production/ Consumption) to be 0.4 instead of the value of 0.5 that was used in the modern mid Bay model. Hagy assumed free bacteria consumed 89 percent of net primary production, $\mathrm{P} / \mathrm{B}$ (production over biomass) equaled 1.13, and the consumption of DOC decreased to 50 percent of the modern mid Bay value $\left(2849 \mathrm{mgC} / \mathrm{m}^{2} /\right.$ day). From these assumptions, C/B and biomass values were estimated as 2.83 and $503 \mathrm{mgC} / \mathrm{m}^{2}$, respectively. Since the 1950s, free bacteria biomass has increased fivefold (Table 1). This was attributed to having a greater amount of dissolved organic matter (DOM), which serves as a food source for free bacteria. The increase in DOM was an indirect result of overabundance of nutrients that increased phytoplankton biomass. Inevitably as part of the life cycle of phytoplankton, phytoplankton mortality occurs resulting in increased DOM biomass. Hagy (2002) estimated the values of parameters used for particle attached bacteria of 1950 os using the same assumptions as free bacteria. These values are presented in Table 1.

\section{Zooplankton}

Zooplankton communities of the modern mid Bay and 1950s restored mid Bay were represented by three components that included microzooplankton, mesozooplankton, and gelatinous plankton. Microzooplankton was the first component of the zooplankton community and consisted of four groups. They were: heterotrophic microflagellates, ciliates, rotifers, and meroplankton. Of these groups, it was assumed that the $1950 \mathrm{OS}$ restored Bay model values of heterotrophic microflagellates and ciliates biomasses and production rates decreased approximately threefold from values used in the modern mid Bay model. This is in keeping with the reduced free bacteria production of the 1950s restored Bay model; especially since free bacteria is the preferred diet for heterotrophic microflagellates (Hagy 2002). Although heteroflagellate production was reduced, there was enough to sustain the ciliates when consumption by ciliates is shifted to more net phytoplankton. For the remaining groups of microzooplankton, rotifers biomass and production rate were assumed to 
be unchanged. However, meroplankton biomass and production rate were assumed to increase approximately sevenfold from modern mid Bay values. Hagy reasoned that because of the more abundant macrobenthos community, meroplanktons, which are larval forms of bottom-dwelling animals would increase as well (Hagy 2002). Mesozooplankton were the second component of the zooplankton community and consisted of all life stages of copepods (Hagy 2002). Biomass and production rate for the modern mid Bay model were approximately 67 percent greater than the values used for the 1950s restored Bay model (Table 1). Phytoplankton biomass was reduced by half of the values used in the modern mid Bay model: consequently, food source for mesozooplankton was an issue in the 1950s. The last component of the zooplankton community was the gelatinous plankton, made up of two groups, ctenophores (Mnemiopsis leidyi) and sea nettles (Chrysaora quinquicirrha). Biomass and production rate of both of these groups remained the same for the modern mid Bay and 1950 os restored Bay models. Diet composition of ctenophores is split between meroplankton, mesozooplankton, and Bay anchovy. With the increase in meroplankton assumed in the 1950s restored Bay model, a shift to this group would alleviate any food shortage caused by the decrease in mesozooplankton. As with the sea nettles, their preference in food source is ctenophores (90 percent), with which their biomass and production rate remain the same.

\section{Benthic animals}

Examining all factors (i.e., predation, salinity, temperature, dissolved oxygen, food availability, etc.) affecting the benthic community of the Chesapeake Bay, Hagy et al. (2004) found that hypoxia had the greatest effect on benthos biomass. They arrived at this conclusion by using empirical models (Gerritsen et al. 1994; Herman et al. 1999) to resolve complex dependencies of the benthic community on habitat conditions. With the understanding that the mid Bay of the 1950s and 6os differed greatly from the present Bay, values for the zoobenthos were set based on conditions believed to have occurred during that period. In the modern mid Bay and 1950s restored Bay models, five groups were included to represent the zoobenthos community. These groups were meiofauna, deposit-feeding benthos, suspension-feeding benthos, blue crab, and oysters. Only three of the five groups' parameters were modified to construct the 1950s model and included meiofauna, deposit-feeding benthos, and suspension-feeding benthos. Meiofauna biomass for the 1950 s restored model was assumed to be the same as the upper and lower 
modern Chesapeake Bay $\left(700 \mathrm{mgC} / \mathrm{m}^{2}\right)$ since hypoxia is not as prevalent in these locations as the mid modern Bay $\left(421 \mathrm{mgC} / \mathrm{m}^{2}\right)$ and would better represent meiofauna biomass of the 1950s. Using ecological relationships from Herman et al. (1999), suspension feeder and deposit feeder biomasses were estimated based on a linear relationship between systemaveraged macrobenthic biomass and primary production of a well-mixed shallow estuary. From this relationship, total macrobenthic biomass of the mid modern Bay was increased by sevenfold in the 1950s restored Bay, and in keeping with the observation that suspension feeder biomass is double deposit feeders, the 1950 os model suspension feeder biomass was set to $6666 \mathrm{mgC} / \mathrm{m}^{2}$ and deposit feeder biomass was $3333 \mathrm{mgC} / \mathrm{m}^{2}$.

\section{Fish}

The only other groups whose parameters were modified from the mid modern Bay model were the demersal feeding fish, spot, and croaker. It stands to reason that if the food source of bottom dwellers increased, then their biomass would increase as well. Using the option in Ecopath to solve for biomass, the estimated biomass for both fish was approximately 42 percent more than what occurred in the mid modern Bay (Table 1).

Once parameter values representing the 1950 s were entered into the input data to replace modern mid Bay values, the network was balanced to satisfy Equations 2 and 4 from Tillman et al. (2006). Of the 34 groups modeled in the Mid Bay, adjustments were made to 19 groups (Table 1). Hagy followed procedures recommended by Christensen and Pauly (1992) to balance the network making only minimal adjustments. Adjustments were mostly to diet composition to produce a balanced mid Chesapeake Bay 1950 s network. 


\section{Ecopath-Informed Simulation}

\section{How does ICM view the 1950s?}

Leading up to the 1950s, historical data and observations have presented the Chesapeake Bay as a thriving and very productive estuary (Cooper and Brush 1993). Since the time of European settlement in the Chesapeake Bay area, a key contributor in the degradation of water quality has been identified as increased human activity and settlement (i.e., agriculture, deforestation, population growth, sewage treatment, and industrialization) (Burnett 1997; Kemp et al. 2005). Before this, impacts to water quality in this area were influenced mostly through climate changes (e.g., hurricanes and heavy snow and rain storm events) and Native American activities (Cooper and Brush 1993). As late as the 180os, waters at Albany, New York were still being described as "crystal clear" (Paul 2001). Much of the blame for increased erosion from agriculture has been credited to the invention of the moldboard plow by Thomas Jefferson around the 1830's. Add this to the attitude of ambivalence toward concern for land conservation and major silting occurred in the upper Chesapeake Bay and major tributaries (Paul 2001). Physical erosion in the Bay has been reduced since the 1940s (Brush 1989).

Over the past 100 years, signs of overenrichment of nutrients (eutrophication) and decreased water clarity were noted in the Chesapeake Bay from sediment core samples (Kemp et al. 2005; Cooper and Brush 1993; Nielsen et al. 2002). An overabundance of nutrients resulting in eutrophication is complemented by higher primary productivity (Paerl et al. 2006; Scavia et al. 2006; Jaworski et al. 1992), which has been linked to anoxic and hypoxic conditions in the Bay (Taft et al. 1980; Officer et al. 1984). In the 1950s there were short periods of seasonal low dissolved oxygen waters, but these periods were short compared to what occurs now (Officer et al. 1984). Episodic anoxia and hypoxia have increased in duration and extent in the bottom waters of the Bay (Cooper and Brush 1993; Kemp et al. 1992). Hypoxia can adversely affect biota and severely hinder ecological interactions leading to detrimental effects on biological communities (Breitburg 2002; Hagy et al. 2004).

The more recent time period of the 1950 s was still considered to have good water quality compared to the modern Bay water quality. Since the 1960 s 
and 1970s, water quality in the Chesapeake Bay has become poorer through overabundance of nutrients and reduced clarity (Kemp et al. 2005). Not only has the water quality become poorer, but biodiversity of the communities of plants and animals has been severely affected to the point that trophic levels are being controlled by different groups. For example, Marshall (1994) demonstrated through microscope analyses that the phytoplankton communities in the Chesapeake Bay switched from being dominated by large cell groups to small cell groups. Zimmerman and Canuel (2002) also verified the shift in phytoplankton communities by looking at biomarker ratios of dinoflagellates and nondiatom algae relative to diatoms, which showed a significant increase in the last century. Because observed historical data are scarce, paleobotanical studies have been conducted to study the ratio of various groups of diatoms to one another to see the change in the past two centuries (Cooper and Brush 1991; Brush 1989).

Plant and benthic communities of the Bay have also declined and shifted to different groups controlling the communities in the past 50 years (Bayley et al. 1978; Kemp et al. 1983; Orth and Moore 1983; Holland et al. 1987; Twilley and Barko 1990; Kemp et al. 2005). From overenrichment, benthic communities suffer from reduced diversity and function (Dauer et al. 2000). Back in the 1950 s and 1960s, the dominant SAV groups were Vallisneria Americana, Najas spp., and Elodea Canadensis. Over time, they have changed to Myriophyllum spicatum (Davis 1985). Decline in communities of SAVs and macrobenthic communities has been correlated to the increased nutrients and sediment inputs from watershed development and urbanization (Kemp et al. 1983, 2005; Malone et al. 1988; Paul 2001). Primarily this has affected the light attenuation in the water column and reduced the production of both communities (Paul 2001; Kemp et al. 2005).

One of the questions this research explored is, "Knowing what we know now about the driving forces of overabundance of nutrients and decreased water clarity, can we go back to conditions that were found in the 1950 s mid Bay?" Making adjustments to loads and coefficients controlling eutrophication through a numerical water quality model is one way to study this problem. In Cerco and Tillman (2008), a run was made with only nutrient loads reduced (90 percent) to try to produce the primary production set in Chesapeake Bay Ecopath by Hagy (2002) for his 1950 s restored Bay run. By doing this, net phytoplankton was reduced to the 
appropriate level but SAV and microphytobenthos biomass did not increase to the level Hagy set. This is because factors other than loads affect growth. This chapter will attempt to improve the previous ICM predictions by adjusting other coefficients associated with SAV and microphytobenthos growth and adjust the loads to those of the 1950s. The approach taken explores the question of whether one can go back in time to the more pristine conditions found in the Chesapeake Bay with thriving communities of SAVs and fish.

\section{Approach}

\section{Model version}

CE-QUAL-ICM was chosen as the water quality model to use for the exercise to recreate 1950 s conditions in the Chesapeake Bay because it has a long history of being calibrated and applied to the system for over 17 years (Cerco and Cole 1994; Cerco and Noel 2004). As mentioned in Tillman et al. (2006), CE-QUAL-ICM (ICM) was designed to be a flexible, widely applicable, state-of-the-art eutrophication model. Several versions of the model have been developed, but the version used for the model runs in this part of the research was the Cerco and Noel (2004) 2002 Chesapeake Bay Eutrophication Model (CBEM). This version contains 24 state variables in the water column (see Table 1 in Cerco and Tillman (2008)) and is linked to a sediment diagenesis model developed by Di Toro and Fitzpatrick (1993). The sediment diagenesis model calculates predictions for up to ten state variables and six fluxes.

The grid used in the model application contained close to 13000 cells (see Figure 1). Approximately 2900 surface cells had non-orthogonal curvilinear coordinates in a horizontal plan. The $\mathrm{z}$ coordinates are in the vertical direction with the deepest part of the Bay being up to 19 layers deep. Layer thickness is fixed at $1.5 \mathrm{~m}$ for the subsurface layers, while the surface layer can vary with forcing functions such as winds and tides.

The hydrodynamics model used to link with ICM was $\mathrm{CH}_{3} \mathrm{D}-\mathrm{WES}$ (Johnson et al. 1993). CH3D-WES produced three-dimensional predictions of velocity, diffusion, surface elevation, salinity, and temperature for each grid cell. Numerically, $\mathrm{CH}_{3} \mathrm{D}$ is a finite-difference formulation having a grid of discrete cells. Inputs to drive the hydrodynamics 


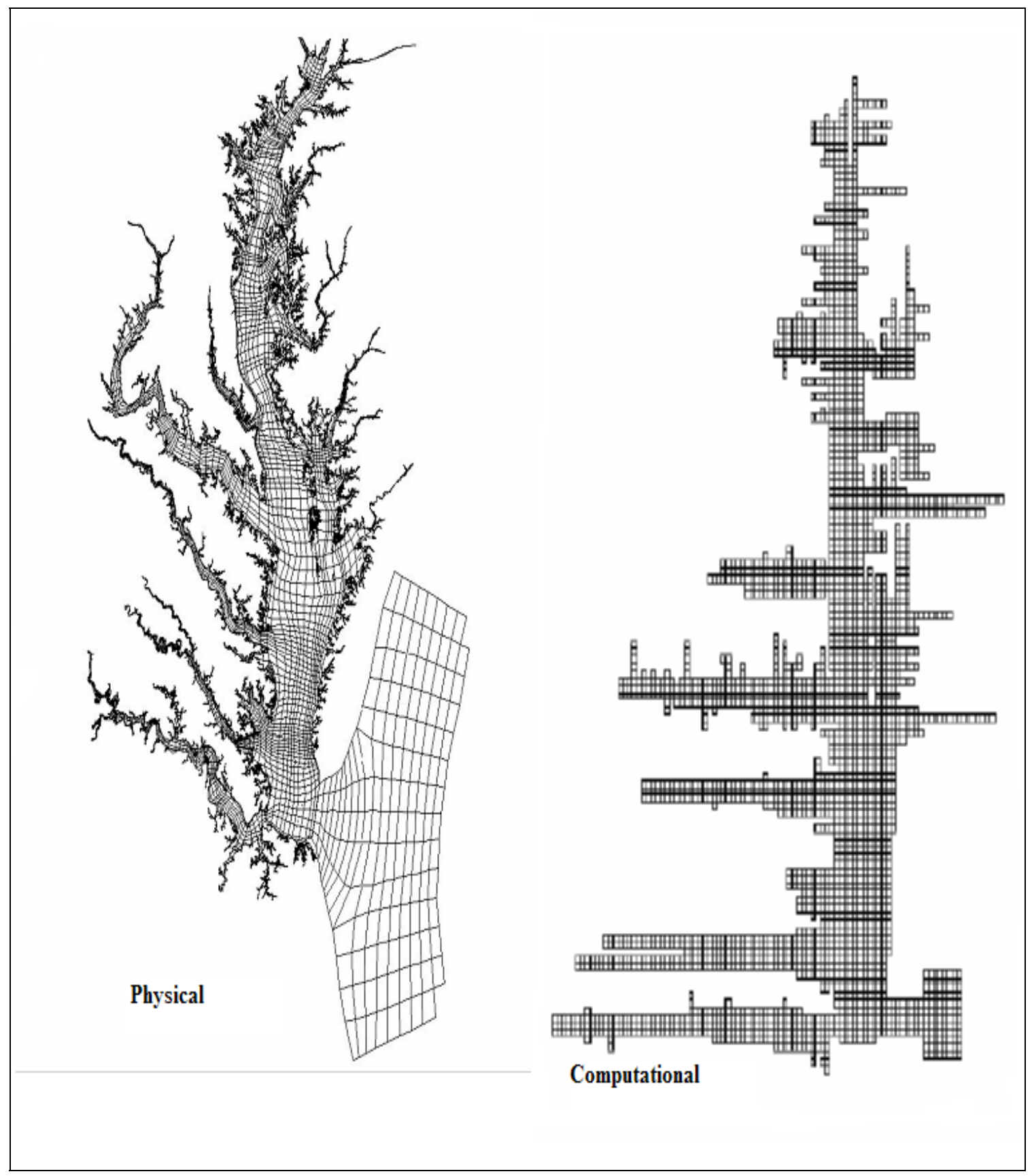

Figure 1. Physical and computational grid of the 13000 cell Chesapeake Bay model (Cerco and Noel 2004).

model included wind speed, air temperature, tributary freshwater inflows, surface heat exchange, tides, and the time-varying vertical distributions of temperature and salinity at the open boundary (Johnson et al. 1993). Ten years, 1985-1994, are simulated continuously using a 5-min time step, and from these, 2-hr hydrodynamics were determined as arithmetic means to be used in the water quality model. The use of intra-tidal hydrodynamics for this application differed from the earliest model application (Cerco and 
Cole 1994) in which Lagrangian-average hydrodynamics was stored at 12.4-hr intervals (Dortch et al. 1992).

The grid characteristics of the hydrodynamics model were the same as described above for the water quality model. The range of the grid is from the heads of tide on the tributaries to the continental shelf in the Atlantic Ocean.

Cerco and Noel (2004) used data to set boundary conditions from the Chesapeake Monitoring Program collected from 1985 to 1994, the EPA Chesapeake Bay Watershed Model (WSM), and reports from regulatory agencies provided to the EPA Chesapeake Bay Program Office. The hydrology was represented by river inflows, lateral inflows, and ocean boundary interfaces. Loads included in modeling the Chesapeake Bay system were from many sources and encompassed types such as non-point loads, point-source loads, atmospheric loads, bank loads, and wetlands loads. For a complete discussion of setting boundary conditions and loads see Cerco and Noel (2004).

Before each simulation, a spin-up period (20 years) was run to allow for changes in nutrient loadings, light extinction, and patchiness to reach their full effect and approach equilibrium to the new conditions. Cerco (1995) reported that it took approximately 10 years for the eutrophication model to show a near-complete response to nutrient load reductions, mostly due to the relatively slow rate of processes in the sediments. Before each scenario run, the eutrophication model was run for 20 years (i.e., looping twice over the 10 years of hydrodynamic data consecutively) and writing out the conditions at the end of the run to use as initial conditions to start the actual scenario runs (i.e., 50 percent reduction of nitrogen $(\mathrm{N})$ and phosphorus $(\mathrm{P})$ or 50 percent light attenuation reduction). The output from each run was then compared to base results (calibration) and each other.

\section{Model runs}

Five simulations using the 2002 CBEM were conducted with analyses only discussed for the mid Bay except when noted. All model runs were simulated for the same time period, 1985 through 1994, but only analyzed for the 1985 through 1987 period. This time period covered two of the years for which Hagy (2002) had developed the Chesapeake Bay Ecopath with Ecosim (EWE) models. The first model run was termed the base run and 
was a re-simulation of the calibration run from the $2002 \mathrm{CBEM}$ recalibration application. This run was used as a reference for comparison to other model runs. Discussion and plots of calibration results and statistics can be found in Cerco and Cole (1994) and Cerco and Noel (2004).

Leading up to the 1950 os restored mid Bay run, two sensitivity runs were conducted to help understand which parameters had the greatest impacts to limiting conditions of the system. Parameters and perturbations for these simulations were:

- 50-percent reduction in nitrogen and phosphorus loads (i.e., point source, non-point source, and tributary)

- 50-percent reduction in nitrogen and phosphorus loads and light attenuation (i.e., the variable, KEISS, in CE-QUAL-ICM).

Setting parameters for the fourth and fifth CE-QUAL-ICM model runs identified as the 1950 os restored mid Bay runs were based on observed and monitored historical values in hopes of producing water quality conditions representative of the 1950s. Changes were made to the same parameters (nutrient loads and light attenuation) modified in the sensitivity runs with the inclusion of an additional parameter, patchiness. Patchiness represents the fraction of the bottom cell covered by plants within an SAV bed. Values chosen for these parameters for the 1950s restored mid Bay run are discussed below.

The following identifiers can be used for run identification within the text:

- 2002 calibration run: base

- Sensitivity run 1: SR-1

- Sensitivity run 2: SR-2

- 1950s restored mid Bay run 1: 1950s RMB1

- 1950 restored mid Bay run 2: 1950 OS RB2

Nutrient loading modifications for 1950's runs

Nutrient concentrations of nitrogen and phosphorus in the 1950 s were less than concentrations found in the mid modern Bay. NO 3 loading data for the Susquehanna River presented in Hagy et al. (2004) were used to estimate how much to reduce values of nitrogen loads used in the 2002 CE-QUAL-ICM CB Model for the 1950 restored mid Bay run. The 
Susquehanna River provides approximately 60 percent of the freshwater flow and 80 percent of the dissolved inorganic nitrogen (DIN) to the Chesapeake Bay so loading conditions should be representative of total loads coming into the Bay. Values of annual averaged $\mathrm{NO}_{3}$ loads with river flow for the Susquehanna River at Harrisburg were graphically presented and showed that annual $\mathrm{NO}_{3}$ loading during the 1945-1969 period was fairly constant averaging $20 \mathrm{Gg} \mathrm{yr}^{-1}\left(\mathrm{Gg}=10^{9} \mathrm{~g}\right)$. This value was converted to annual TN using the relationship Hagy et al. (2004) developed, which correlates the $\mathrm{TN}$ loading at Conowingo to $\mathrm{NO}_{3}{ }^{-}$loading at Harrisburg and is written:

$$
L_{T N, C}=-0.16+1.99 * L_{\mathrm{NO}, H}\left(r^{2}=0.90\right)
$$

The resulting value was then compared to total nitrogen (TN) load data from Cerco and Cole (1994). A ratio of historic Bay loads to Hagy et al. (2004) loads was calculated and used as the multiplication factor for reducing the 2002 Chesapeake Bay Model TN loads to values for the 1950's run. The calculated ratio was 0.58 .

The multiplication factor for reducing total phosphorus (TP) loads to 1950 conditions was estimated based on atomic ratios. Using load data from the 1994 calibration, the ratio of TN to TP was found using the equation:

$$
1950 N=1985 N \times 0.58
$$

and

$1950 P=1983 P \times \frac{0.58 \mathrm{~kg} 1950 \mathrm{~N}}{1 \mathrm{~kg} 1983 \mathrm{~N}} \times \frac{22.8 \mathrm{~kg} 1983 \mathrm{~N}}{\mathrm{~kg} 1983 P} \times \frac{\mathrm{kg} 1950 P}{18.9 \mathrm{~kg} 1950 \mathrm{~N}}$

$1950 P=1983 P \times 0.703$

Light attenuation for sensitivity and 1950's runs

From historical pictures of SAV beds and written observation, inference can be made that water was much clearer in the Chesapeake Bay than at present (Orth and Moore 1986). Based on this, Hagy (2002) assumed light attenuation was half of the present day value of $0.8 \mathrm{~m}^{-1}$. Light attenuation $\left(K_{e}\right)$ in CE-QUAL-ICM is modeled as spatially varying and is solved as: 


$$
K e=a_{1}+a_{2} \cdot I S S+a_{3} \cdot V S S
$$

where:

$$
\begin{aligned}
a_{1} & =\text { background attenuation }\left(\mathrm{m}^{-1}\right) \\
a_{2} & =\text { attenuation by inorganic suspended solids }\left(\mathrm{m}^{-1}\right) \\
I S S & =\text { inorganic fixed solids }\left(\mathrm{gm}^{-3}\right) \\
a_{3} & =\text { attenuation by organic suspended solids }\left(\mathrm{m}^{-1}\right) \\
V S S & =\text { organic solids }
\end{aligned}
$$

For each segment of the Chesapeake Bay (Figure 2) in the model domain, coefficients of the equation were determined and listed in Table 11-2 from Cerco and Noel (2004). To be consistent with Hagy, calculated values of $K_{e}$ are halved during the CE-QUAL-ICM 1950s restored mid Bay and sensitivity runs.

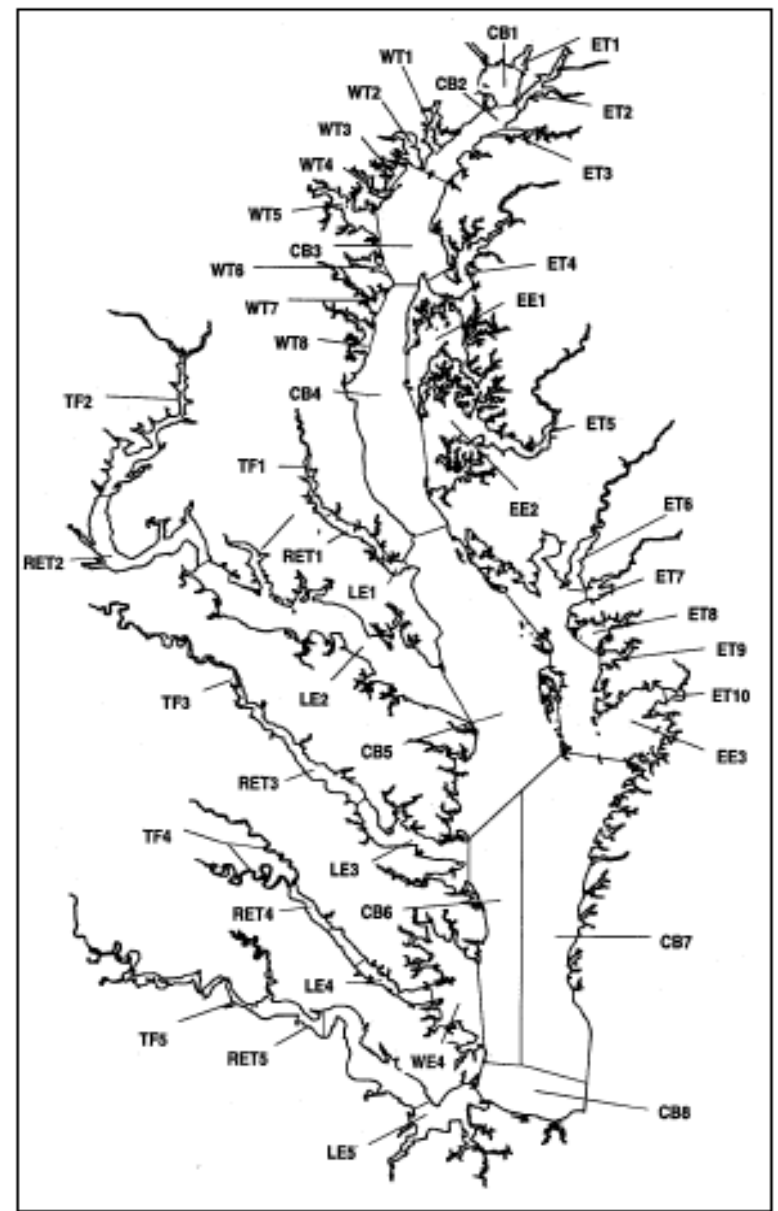

Figure 2. Chesapeake Bay Program Segments. 
SAV coverage for sensitivity and 1950's runs

Present day coverage of SAV beds is believed to grow to about the 1-m depth while during the 1950 s aerial photographs showed SAV coverage possibly grew in waters up to $2 \mathrm{~m}$ in depth (Orth and Moore 1986). In the CE-QUAL-ICM formulation of SAV, SAV beds form a ribbon of littoral cells along the land-water margin of the system. Because the goal of SAV restoration has been set to the 2-m contour line, width of littoral cells in the model is represented as the distance to the 2-m contour (Cerco and Noel 2004). To allow SAV to grow within a cell, a variable called patchiness was adjusted. It represents the fraction of bottom area covered by plants. This variable is found in the equation for estimating abundance within a cell and is:

$$
M=S H \times A \times T E \times C \times P
$$

of which:

$$
\begin{aligned}
M & =\text { aboveground abundance }(\mathrm{g} \mathrm{C}) \\
S H & =\text { shoot biomass }\left(\mathrm{g} \mathrm{Cm}^{-2}\right) \\
A & =\text { cell surface area }\left(\mathrm{m}^{2}\right) \\
T E & =\text { truncation error } \\
C & =\text { coverage } \\
P & =\text { patchiness. }
\end{aligned}
$$

For sensitivity runs this patchiness remained at 0.1 ; however, for the 1950's restored mid Bay run, it was adjusted from 0.1 to 0.5 .

\section{Sensitivity results presentation}

Two forms of graphical plots were used to compare base results with sensitivity results. The plots were time series of nutrient limitations and histograms of groups common to both CE-QUAL-ICM and Ecopath.

\section{Time series}

Results for the CE-QUAL-ICM base model run were compared to results for both sensitivity model runs through daily time series plots of nutrient limitations for the primary producer groups: phytoplankton, benthic algae, and SAV. Daily time series plots were developed for the simulation period of 1985 through 1987. Since three groups of phytoplankton were modeled 
in the CE-QUAL-ICM applications (i.e., cyanobacteria, green, and diatoms), nutrient limitation values for the phytoplankton group were calculated as an averaged biomass-weighted, areal average using the following equations:

$$
\text { Algae limit }=\frac{\sum S A \bullet\left(B_{1} \bullet F N+B_{2} \bullet F N+B_{3} \bullet F N\right) /\left(B_{1}+B_{2}+B_{3}\right)}{\sum S A}
$$

where:

$$
S A=\text { surface area of cell }\left(\mathrm{m}^{2}\right)
$$

$B_{1}, B_{2}, \& B_{3}=$ algal concentrations for algal groups $1,2, \& 3\left(\mathrm{mgm} \mathrm{m}^{-3}\right)$

$F N=$ nutrient limitation (dimensionless).

Values of nutrient limitations for the other two primary producers (benthic algae and SAV) were calculated as an areal average using the equations below:

$$
\text { Benthic Algae Limit }=\frac{\sum S A \bullet F N}{\sum S A}
$$

where:

$$
\begin{aligned}
& S A=\text { surface area of cell }\left(\mathrm{m}^{2}\right) \\
& F N=\text { nutrient limitation (dimensionless). }
\end{aligned}
$$

$$
S A V L I M I T=\frac{\sum S A \bullet F N}{\sum S A}
$$

These plots demonstrate the range of nutrient limitation where a value of zero is equivalent to total growth inhibition and a value of one is equivalent to no inhibition. Limitations of the primary producers are shown in Figures 3 to 5 . 


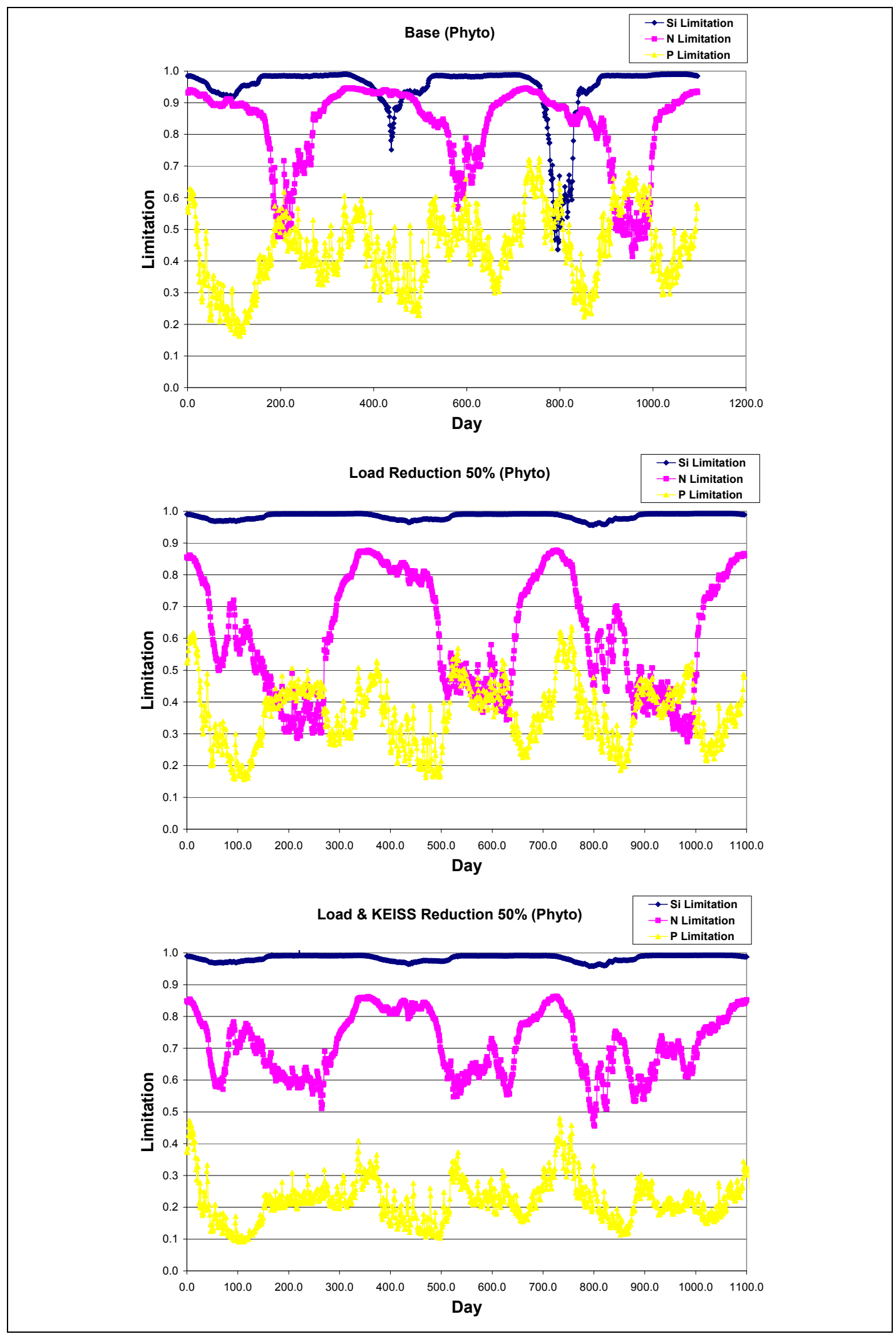

Figure 3. Phytoplankton limitation results for base, SR1, and SR2 in the mid Chesapeake Bay. 

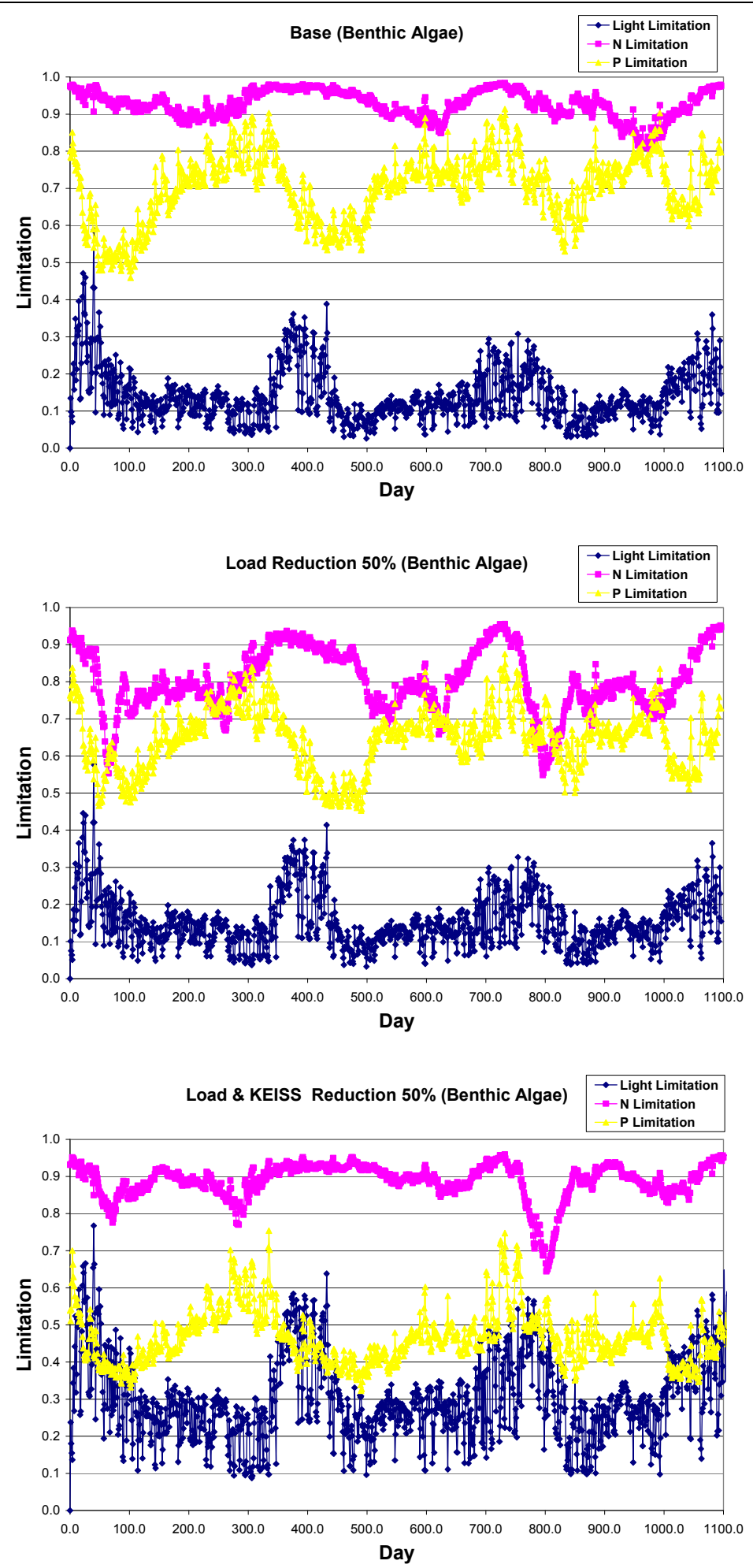

Figure 4. Microphytobenthic algae limitation results for base, SR1, and SR2 for the mid Chesapeake Bay. 


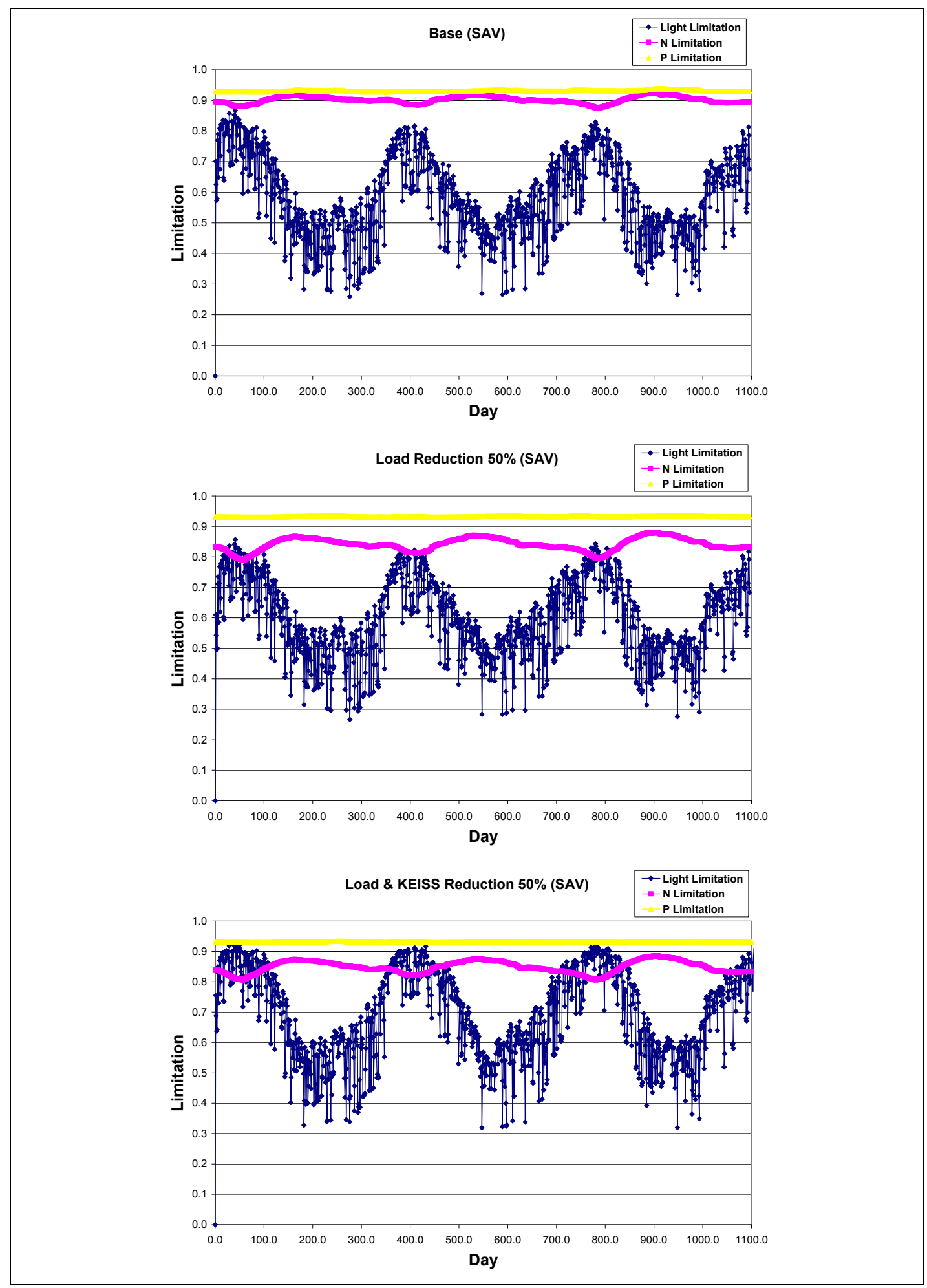

Figure 5. SAV limitation results for base, SR1, and SR2 in the mid Chesapeake Bay. 


\section{Histograms}

Histograms of biomass, $\mathrm{P} / \mathrm{B}$ (production over biomass) ratios, Q/B (consumption over biomass) ratios, and UA/B (unassimilated food over biomass) ratios are presented for each group of interest in Figures 6 through 9. Each histogram represents the summer average of 1986 (June 1 through August 31) of each variable plotted from the groups of interest.

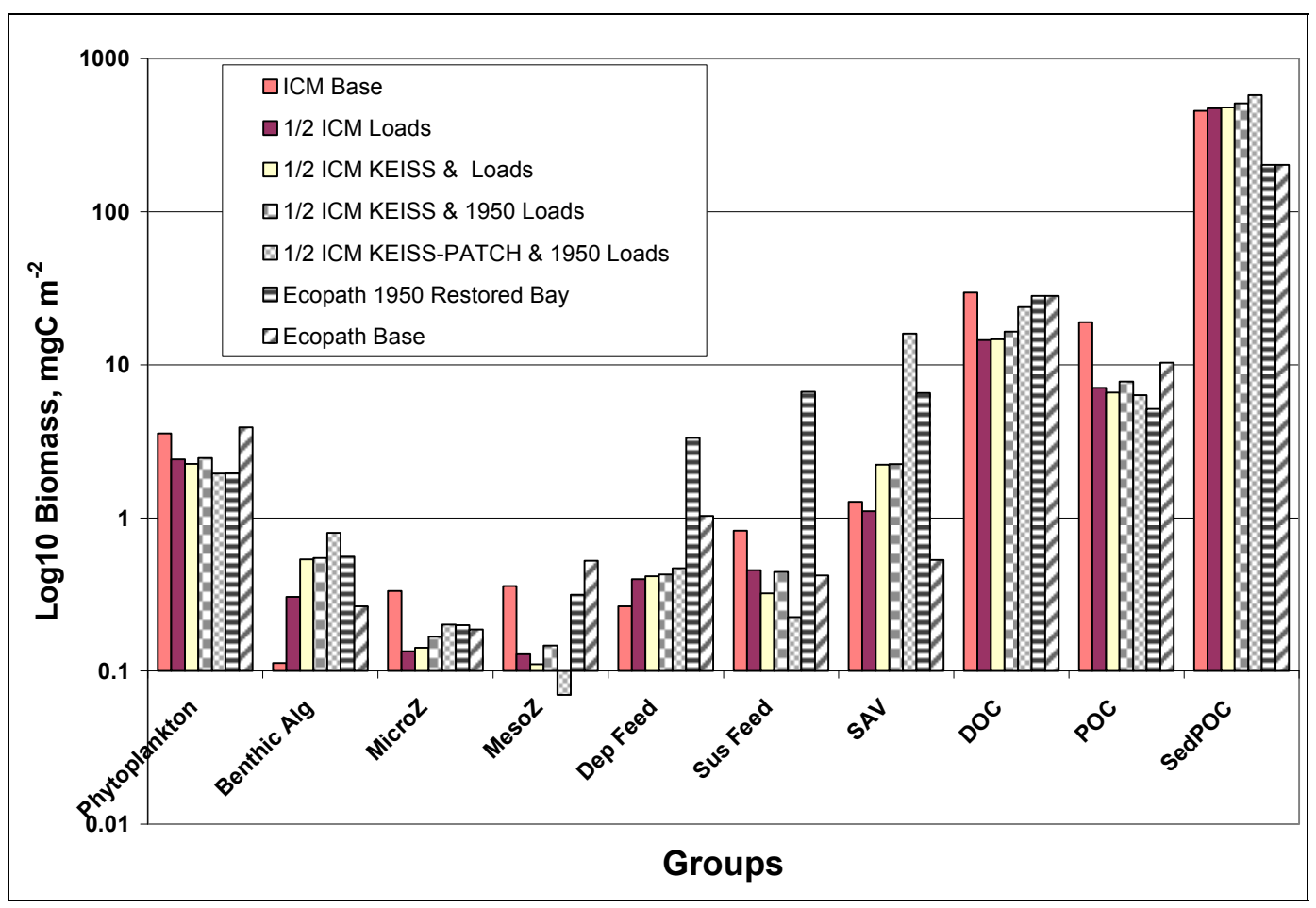

Figure 6. Comparison of biomasses for each group common to ICM and Ecopath. 


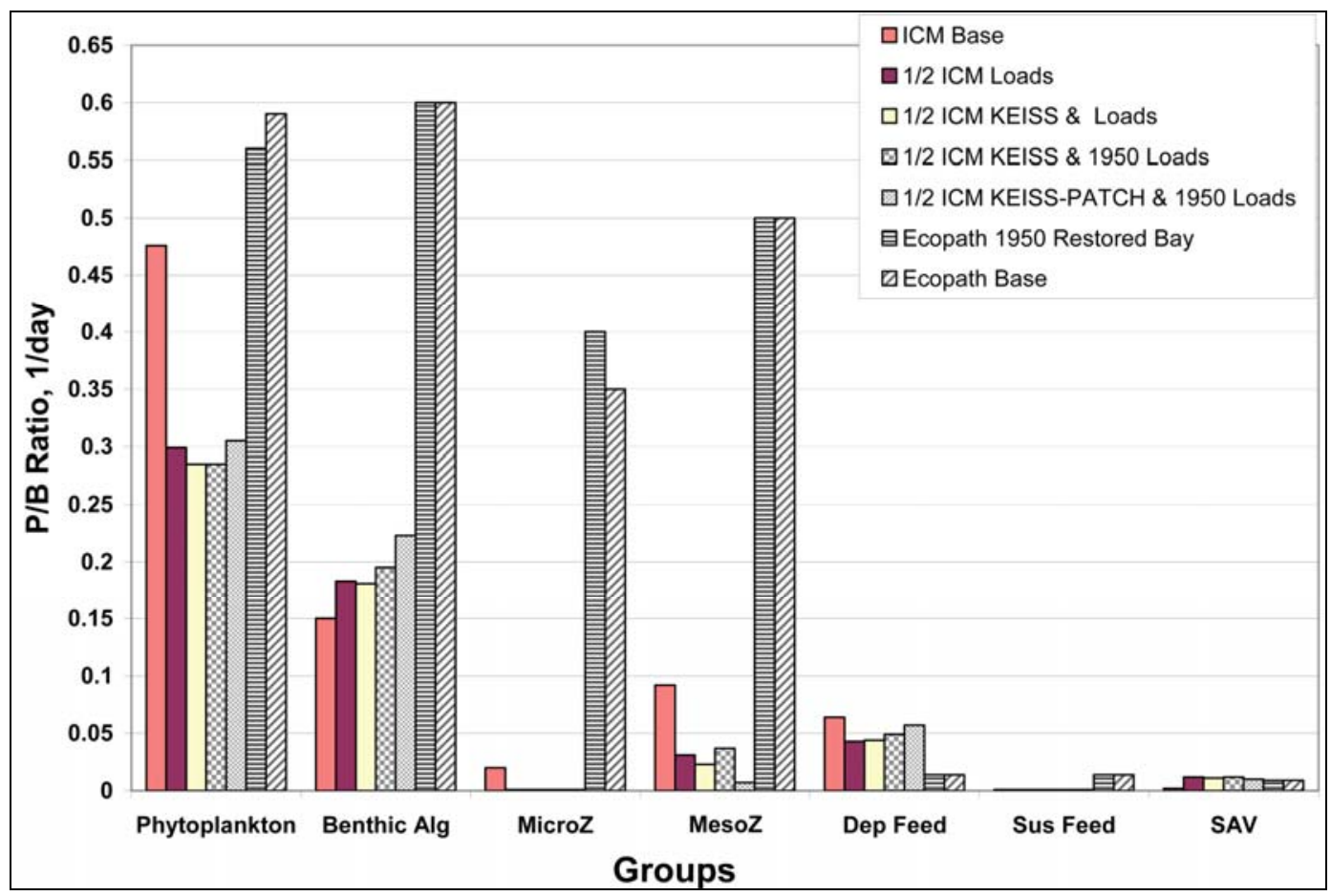

Figure 7. Comparison of ICM and Ecopath P/B ratios.

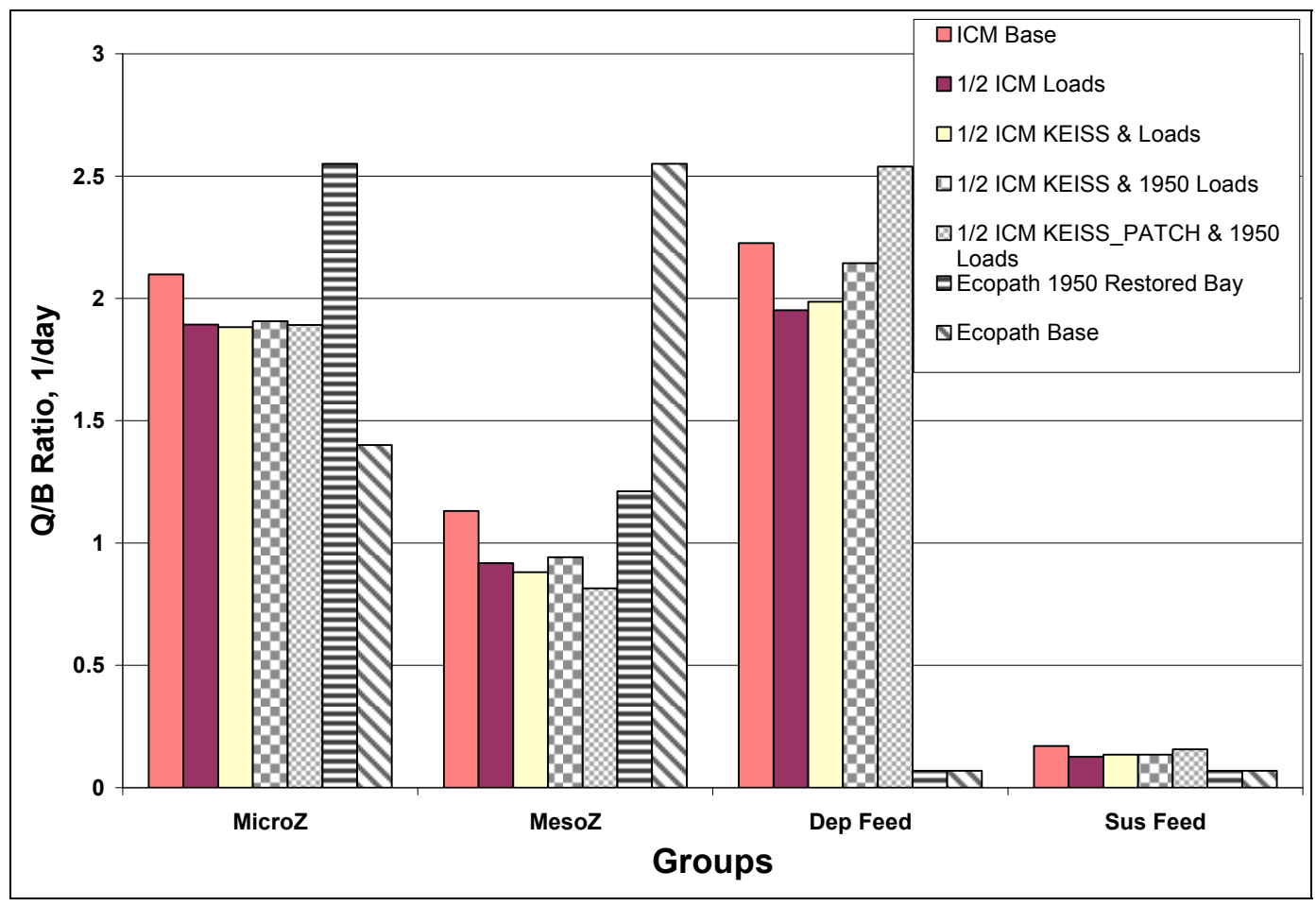

Figure 8. Comparison of ICM and Ecopath Q/B ratios. 


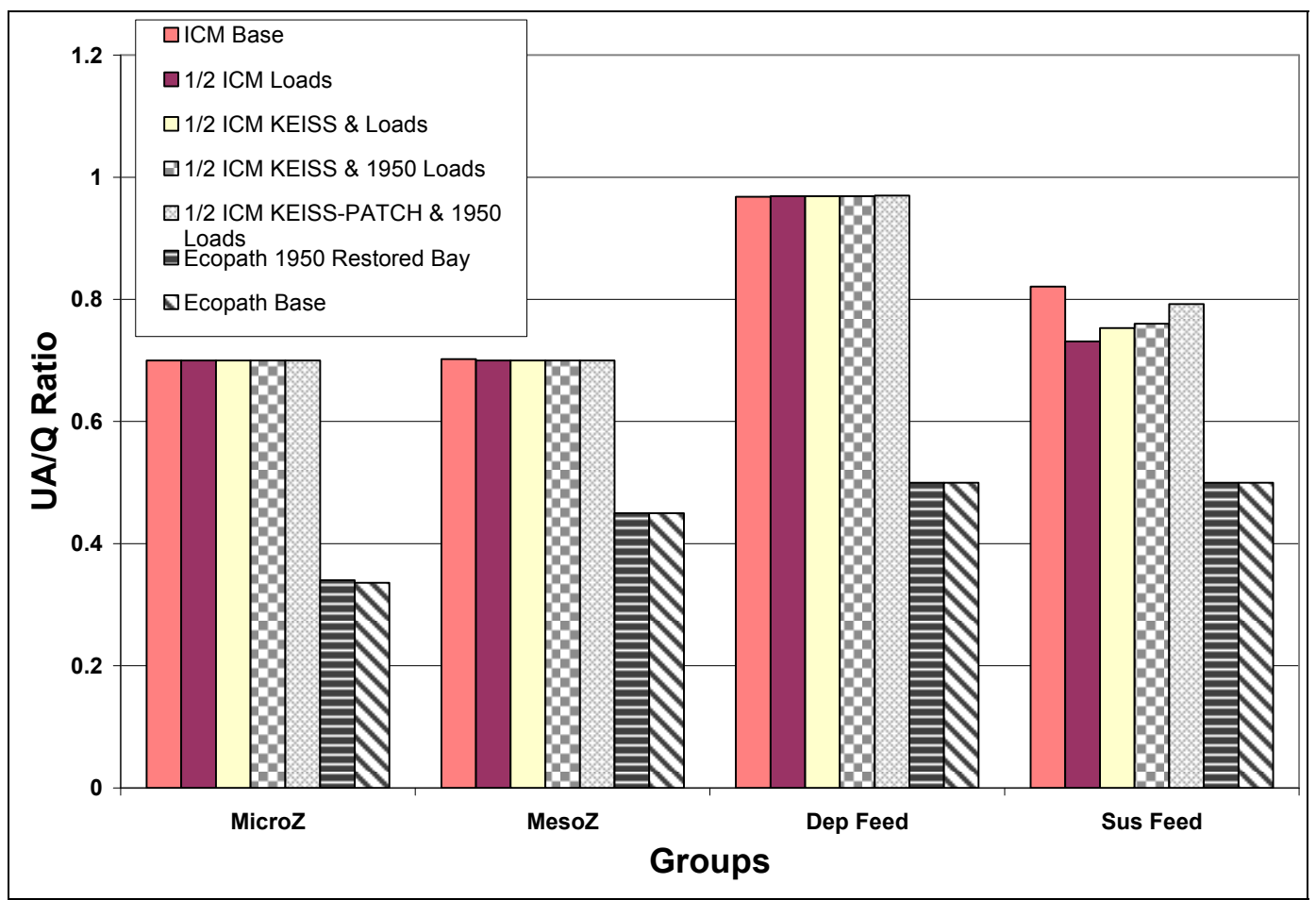

Figure 9. Comparison of UA/Q ratios from ICM to values used in Ecopath.

\section{0s restored mid Bay result presentation}

Four graphical plots were used to compare base results with the $1950 \mathrm{OS}$ restored mid Bay results. They include time series, histograms, longitudinal, and DO volume-day plots. Variables plotted as histograms were included on Figures 6-9 discussed previously for the sensitivity run results. Other graphical forms used to compare the 1950's restored mid Bay results to base results are discussed below.

\section{Time series}

The CE-QUAL-ICM base model results were compared to 1950 os mid modern Bay model results through time series plots. Figures 10-30 were developed for the complete simulation period (1985 through 1987) for all variables most affected by adjustments to nutrient loads and coefficients in an attempt to generate water quality conditions of the 1950s. These included the variables: chlorophyll $a$, dissolved oxygen (DO), total nitrogen (TN), total phosphorus (TP), nutrient and light limitations, and light extinction. These plots demonstrate model performance over time and indicate interactions between modeled parameters. 
Results are shown for the three regions of the Chesapeake Bay (upper, mid, and lower as denoted in Figure 31) as defined by Hagy (2002). For each region, time series plots were developed for three levels in the water column:

- Surface level - upper four layers of grid (Figures 10-14).

- Pycnocline level - next four layers of grid (Figures 15-18).

- Deep water level - all cells below layer eight of grid (Figures 19-22).

A volumetric average of concentration is displayed on each plot for the variables listed previously. In addition to volumetric concentration time series for each region, time series were also developed to present algae as biomass per unit area $\left(\mathrm{mg} \mathrm{CHL} \mathrm{m}^{-2}\right)$ using the formula:

$$
\text { Alg Biomass }=\frac{\sum\left(\left(B_{1} / \operatorname{cchl} 1+B_{2} / \operatorname{cchl} 2+B_{3} / \operatorname{cchl} l 3\right) * S A\right) * \Delta z}{\sum R S A}
$$

where:

$$
\begin{aligned}
B_{1}, B_{2}, \& B_{3}= & \text { algal concentrations for algal groups } 1,2, \& 3(\mathrm{mgm} \\
& \left.\mathrm{m}^{-3}\right) \\
c \operatorname{chl}_{1}, c c h l_{2}, \& c c h l_{3}= & \text { carbon to chlorophyll ratio } \\
S A= & \text { surface of cell } \\
\Delta Z= & \text { layer thickness } \\
R S A= & \text { regional surface area. }
\end{aligned}
$$

These time series are shown in Figures 23 through 25.

\section{Longitudinal plots}

Summer averages for all years modeled were calculated for chlorophyll $a$, DO, TN, TP, and light attenuation for the base run and the 1950 s restored mid Bay run. Surface and bottom concentration of CHL $a$, DO, TN, and TP were plotted along the longitudinal distance from the confluence of the Susquehanna River with the mainstem of the Chesapeake Bay to the ocean boundary. Light attenuation was plotted for only the surface layer. These averages presented in longitudinal plots provide a synopsis of the changes occurring along the longitudinal profile of the main channel of the Chesapeake Bay resulting from modifications to nutrient loads, light attenuation, and SAV patchiness. Results for longitudinal profiles are presented in Figures 26 through 30. 

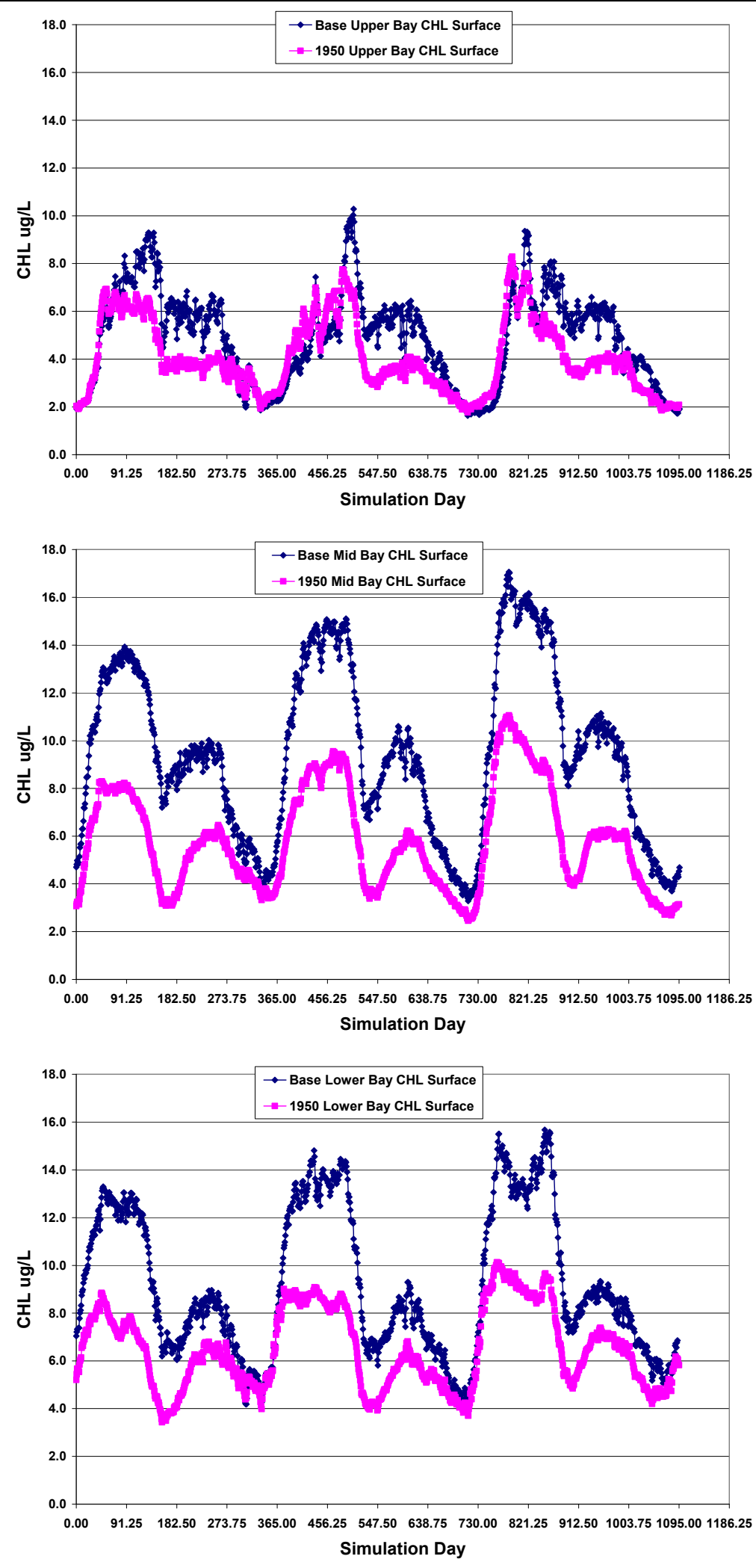

Figure 10. Comparison of surface Chlorophyll a for base and 1950s RMB2 results in the upper, mid, and lower regions of the Chesapeake Bay. 

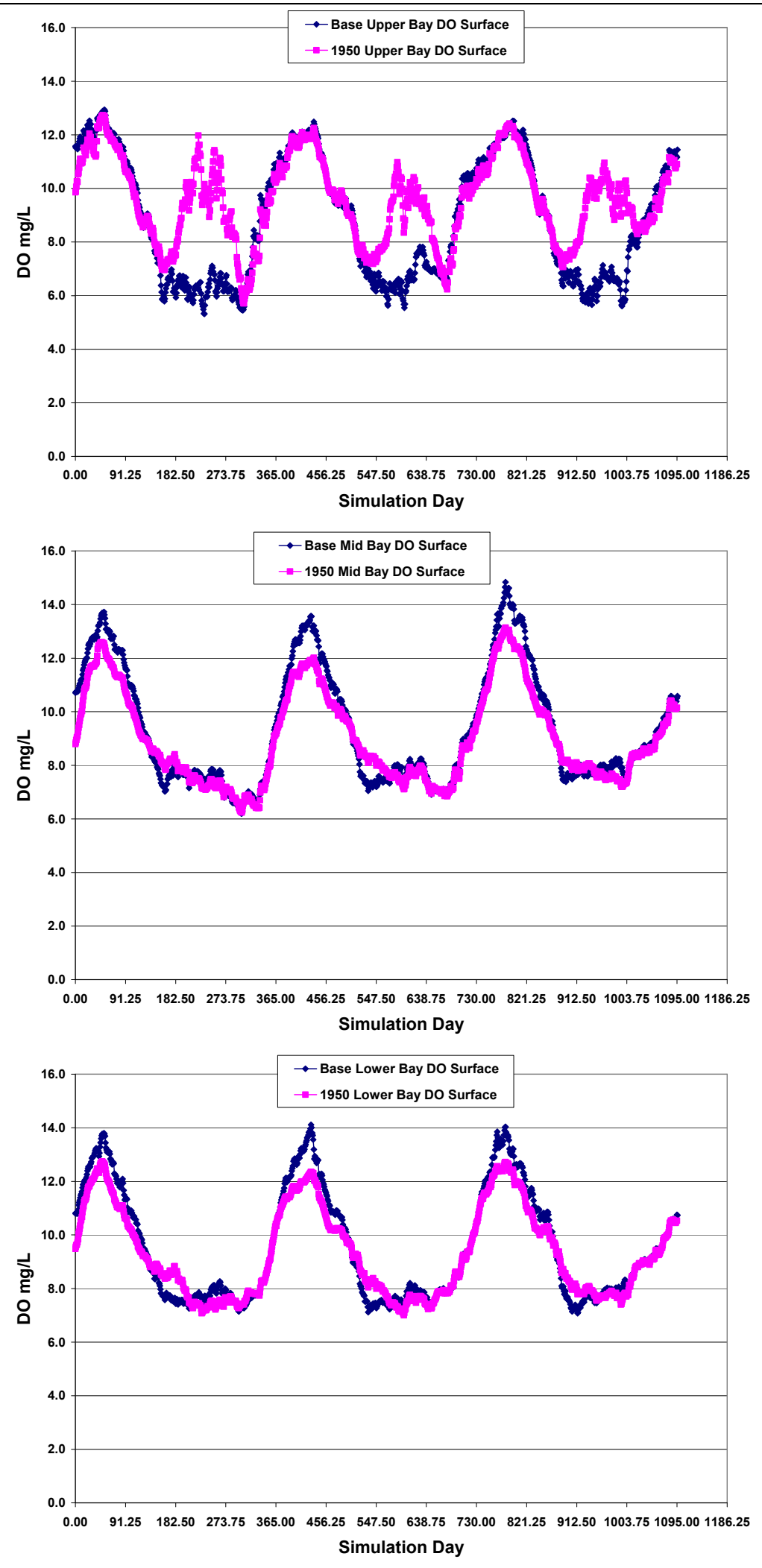

Figure 11. Comparison of surface DO for base and 1950's RMB2 results in the upper, mid, and lower regions of the Chesapeake Bay. 

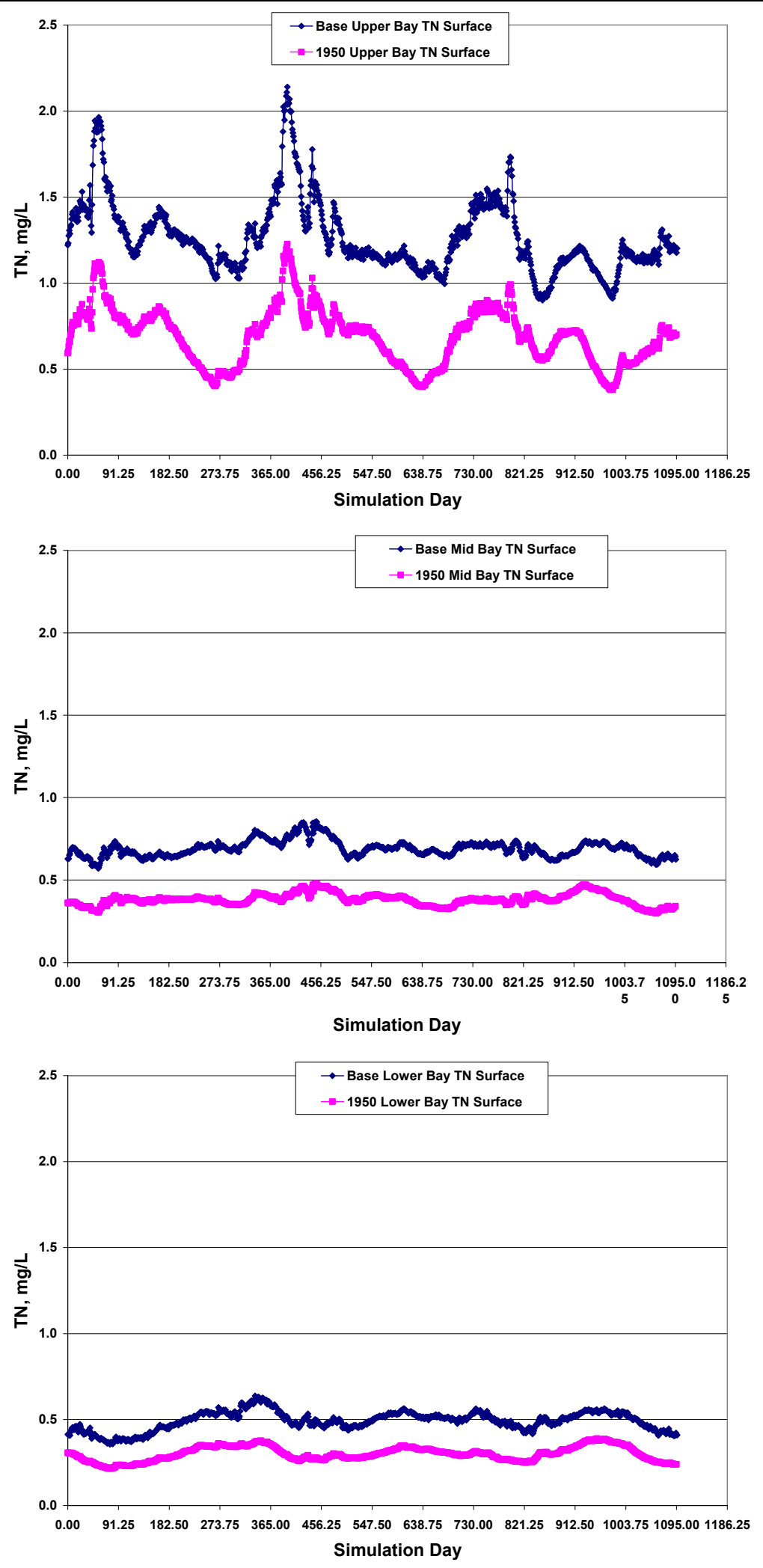

Figure 12. Comparison of surface TN for base and 1950's RMB2 results in the upper, mid, and lower regions of the Chesapeake Bay. 


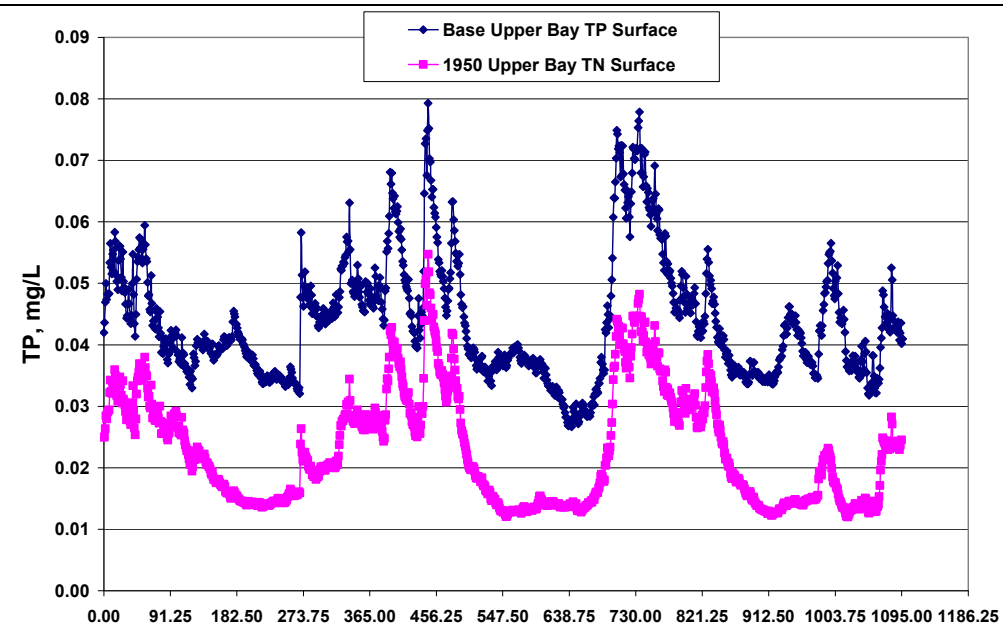

Simulation Day

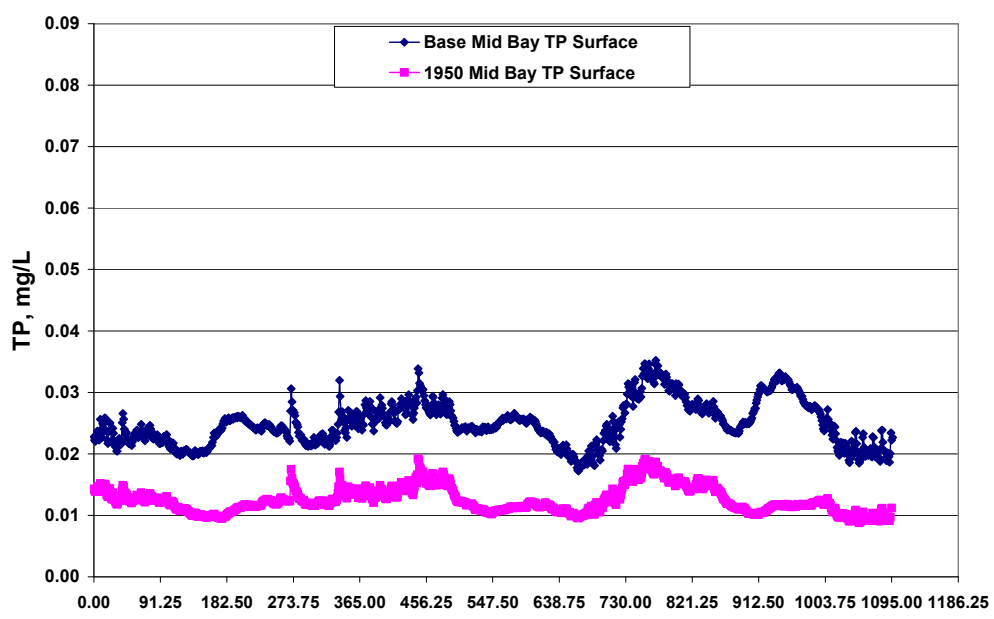

Simulation Day

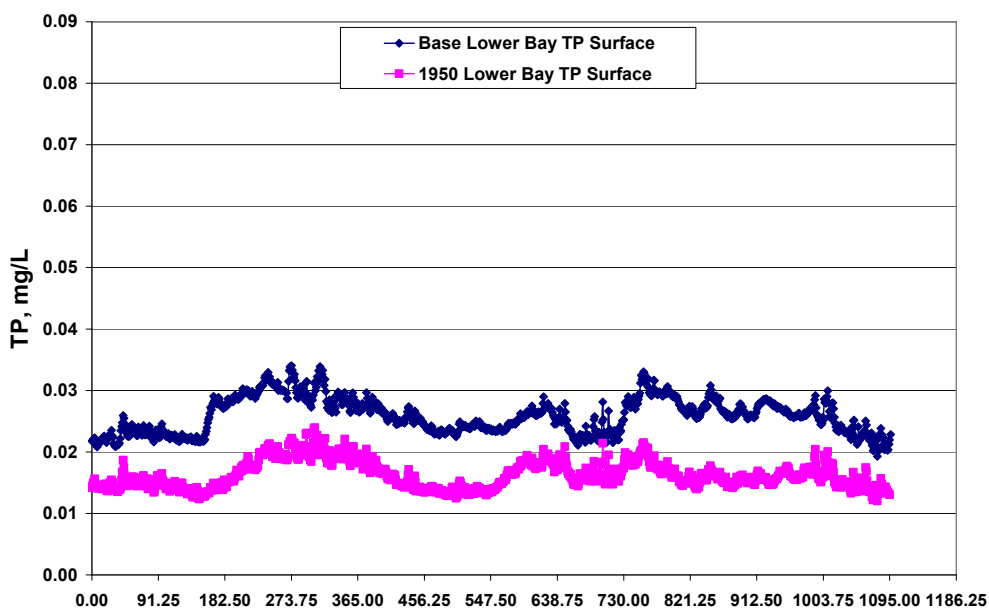

Simulation Day

Figure 13. Comparison of surface TP for base and 1950's RMB2 results in the upper, mid, and lower regions of the Chesapeake Bay. 


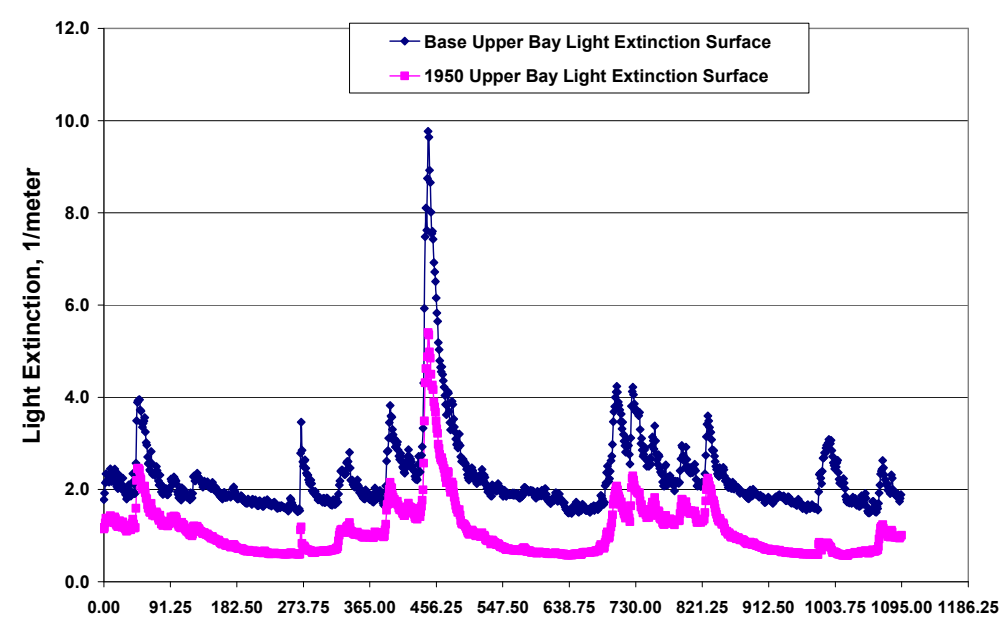

Simulation Day

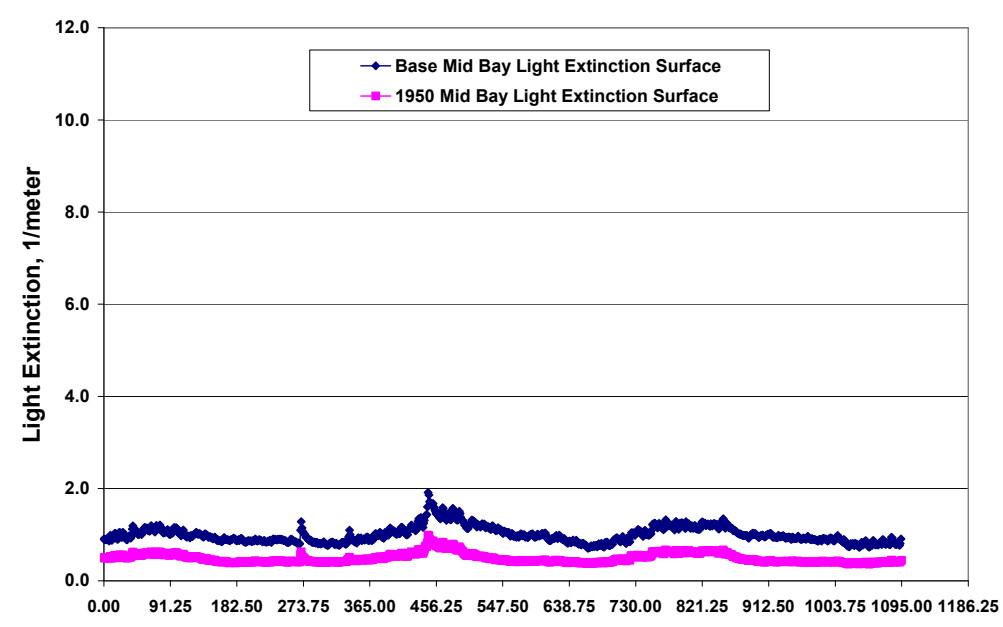

Simulation Day

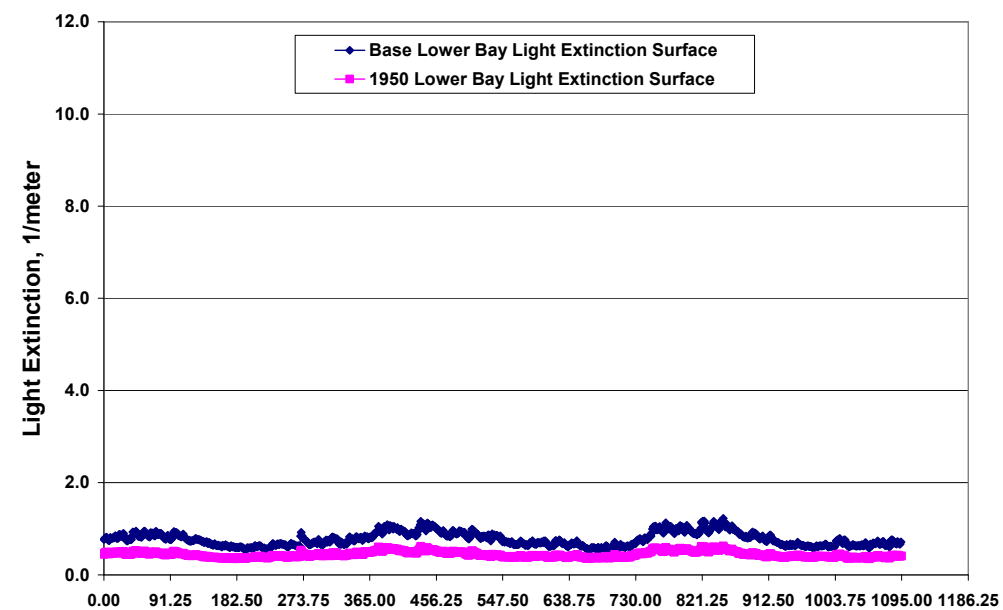

Simulation Day

Figure 14. Comparison of surface light extinction for base and 1950's RMB2 results in the upper, mid, and lower regions of the Chesapeake Bay. 


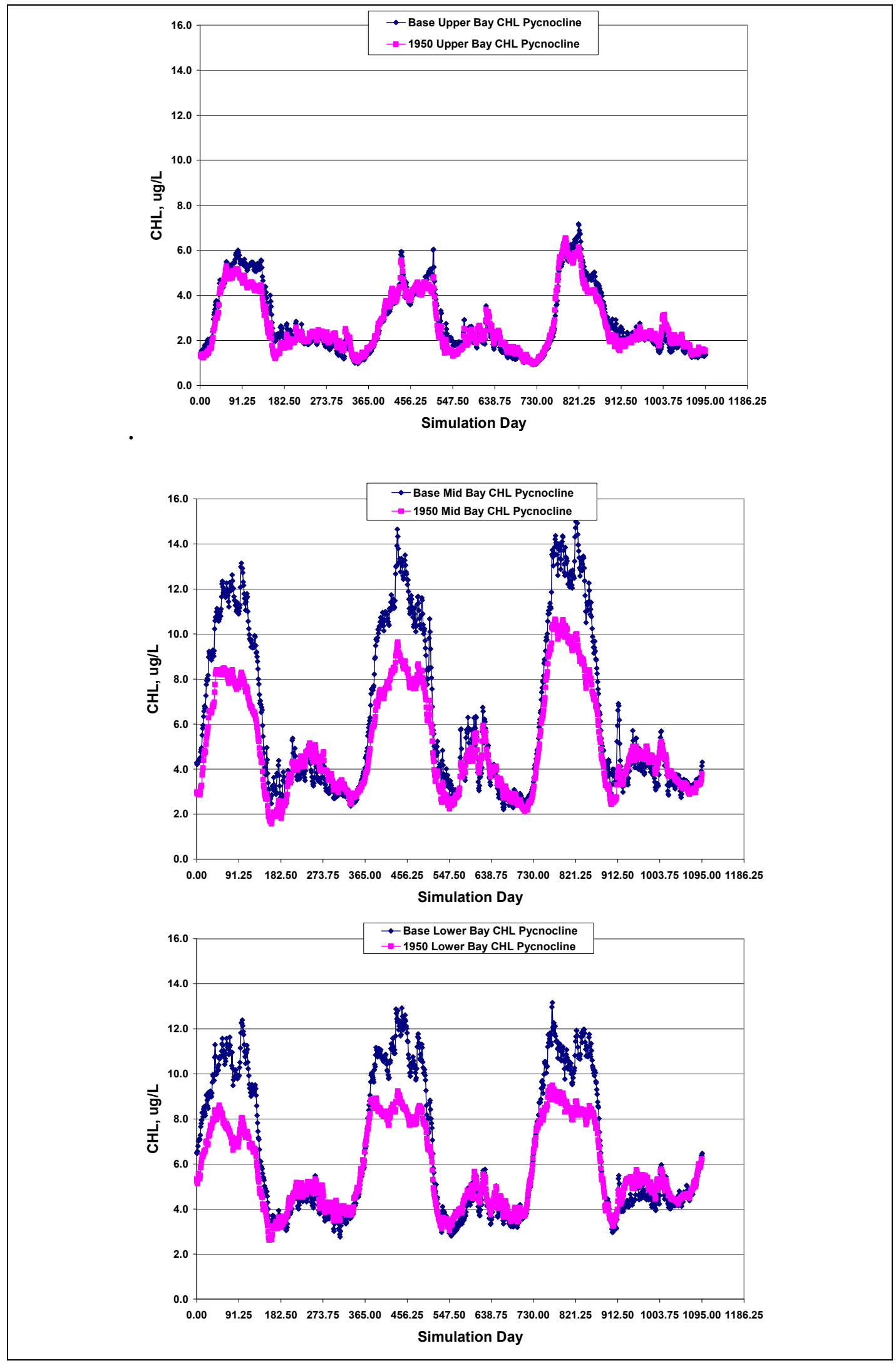

Figure 15. Comparison of the pycnocline Chlorophyll a for base and 1950's RMB2 results in the upper, mid, and lower regions of the Chesapeake Bay. 


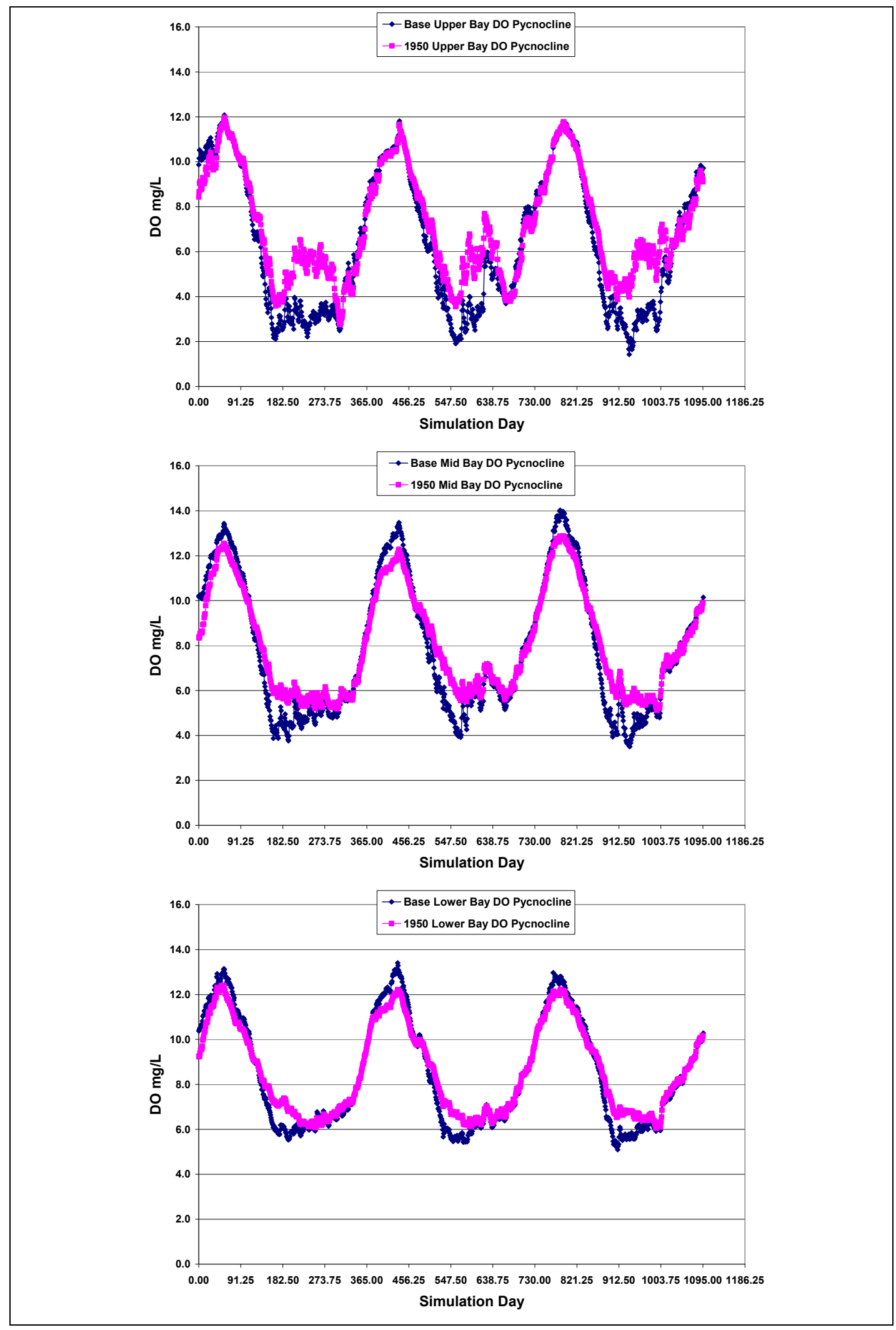

Figure 16. Comparison of the pycnocline DO for base and 1950's RMB2 results in the upper, mid, and lower regions of the Chesapeake Bay. 

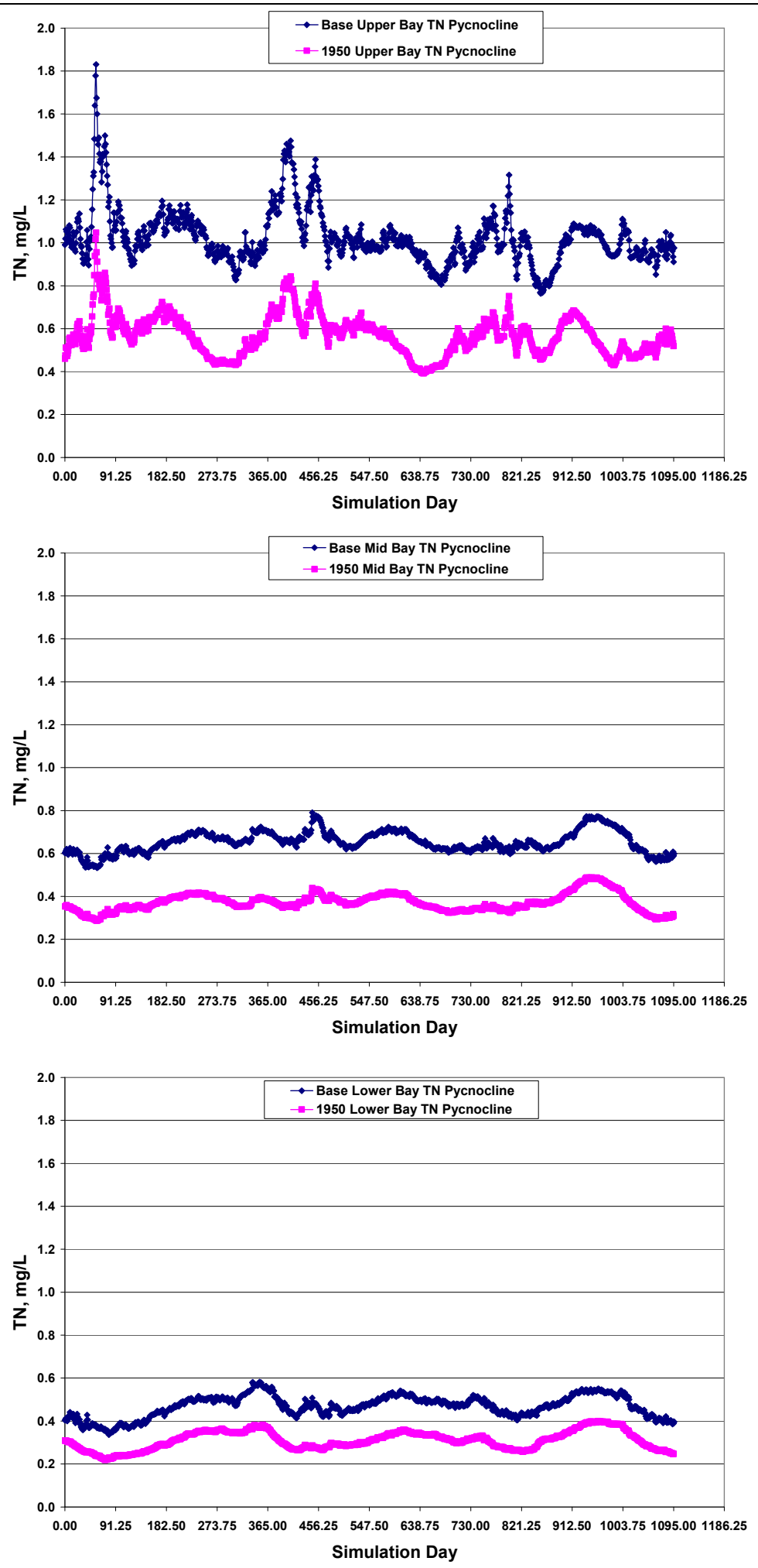

Figure 17. Comparison of the pycnocline TN for base and 1950's RMB2 results in the upper, mid, and lower regions of the Chesapeake Bay. 


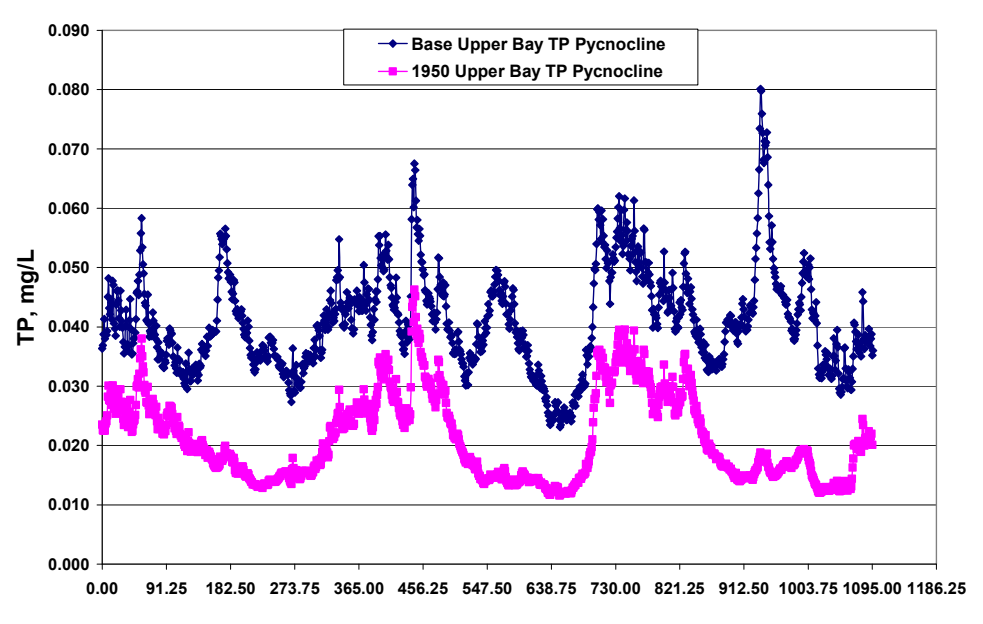

Simulation Day

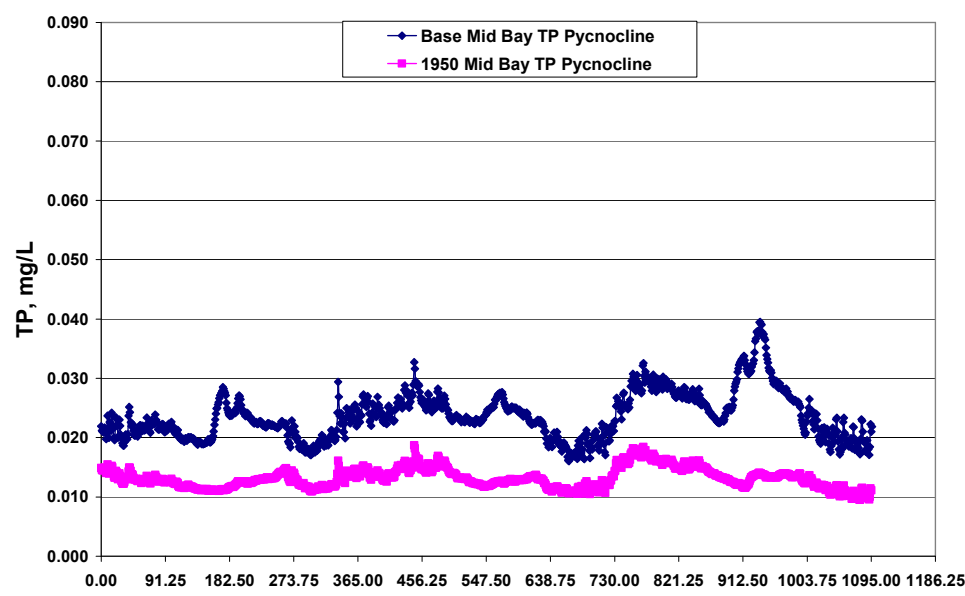

Simulation Day

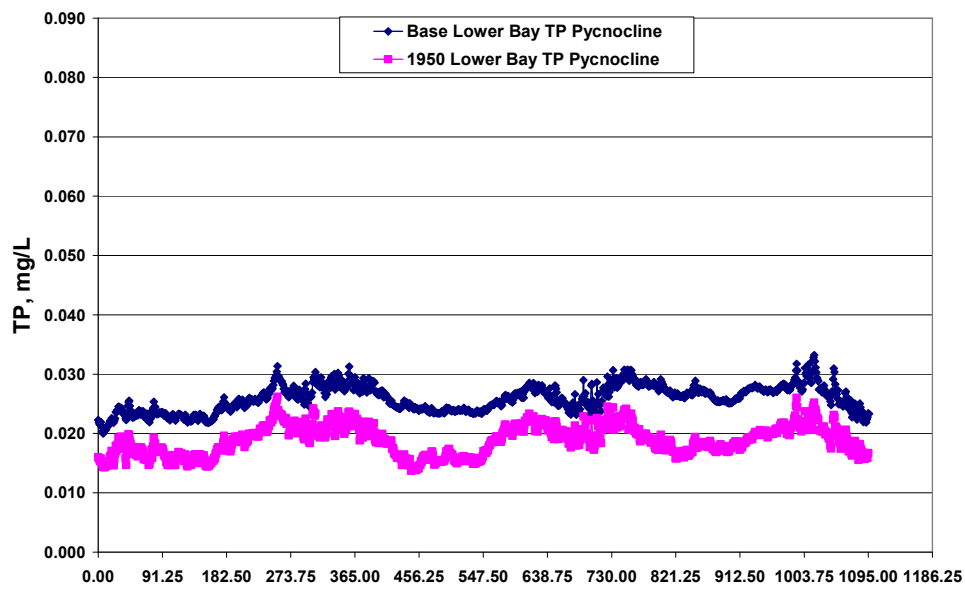

Simulation Day

Figure 18. Comparison of the pycnocline TP for base and 1950's RMB2 results in the upper, mid, and lower regions of the Chesapeake Bay. 

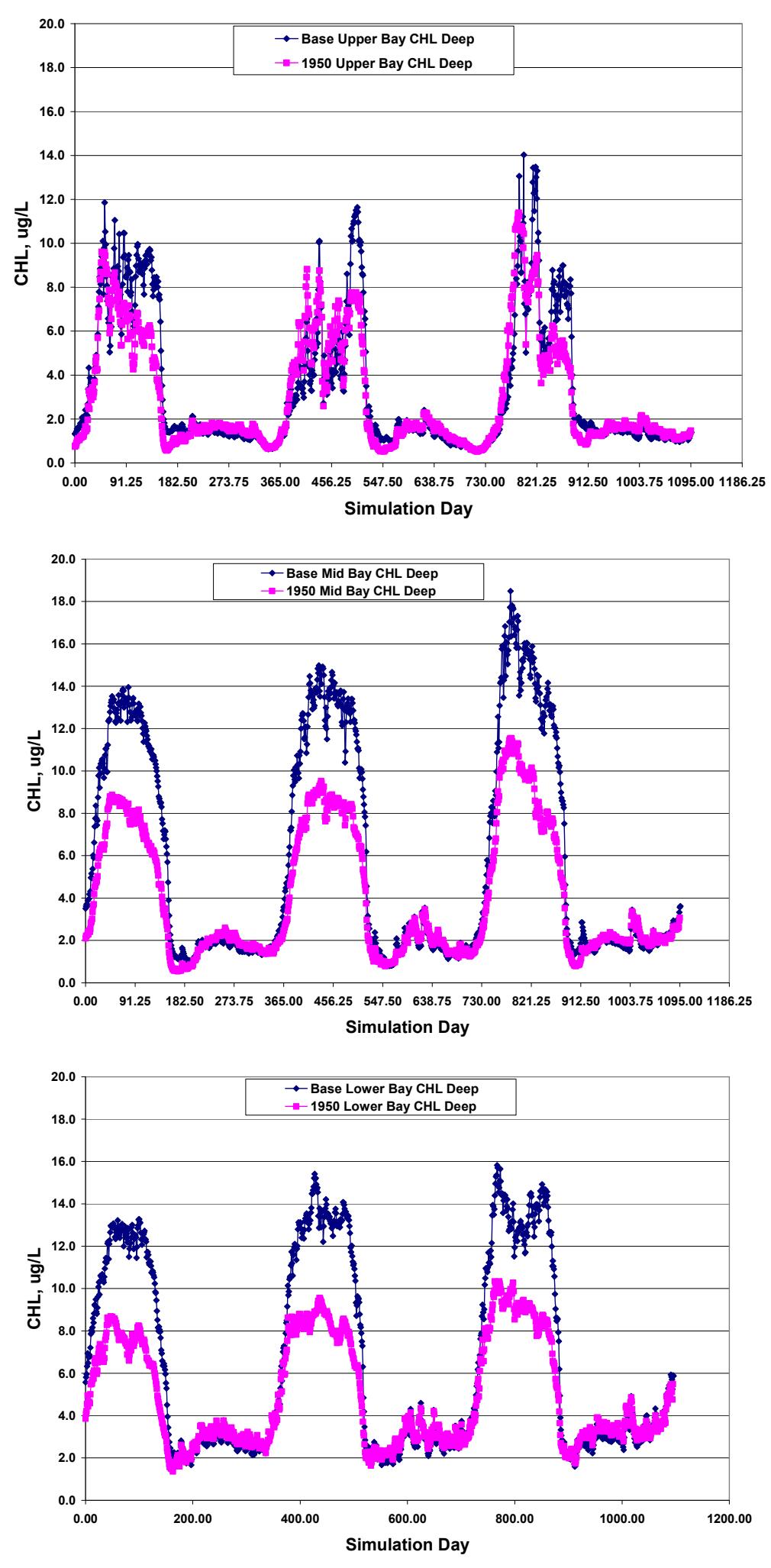

Figure 19. Comparison of the deep chlorophyll a for base and 1950's RMB2 results in the upper, mid, and lower regions of the Chesapeake Bay. 


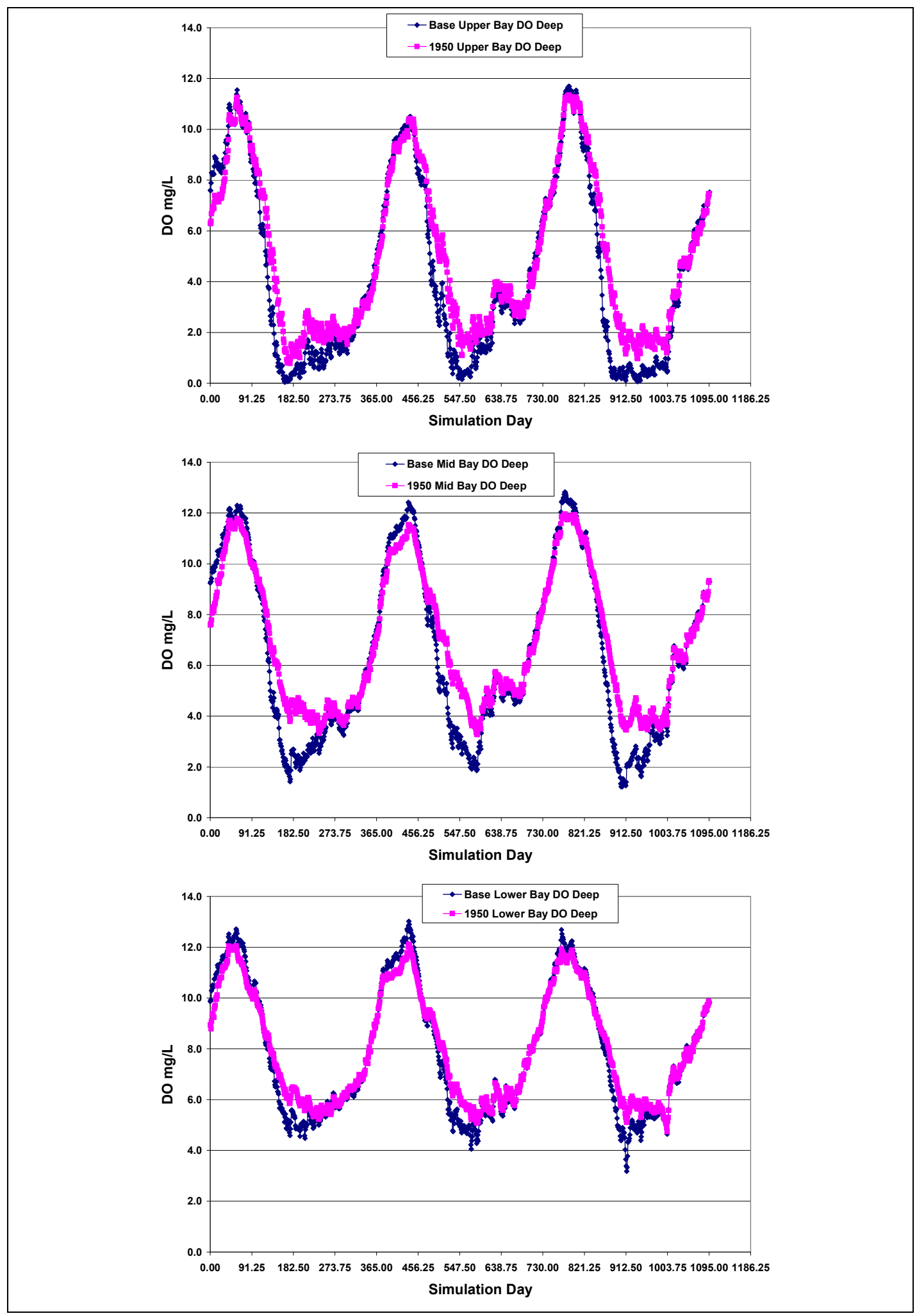

Figure 20. Comparison of the deep DO for base and 1950's RMB2 results in the upper, mid, and lower regions of the Chesapeake Bay. 

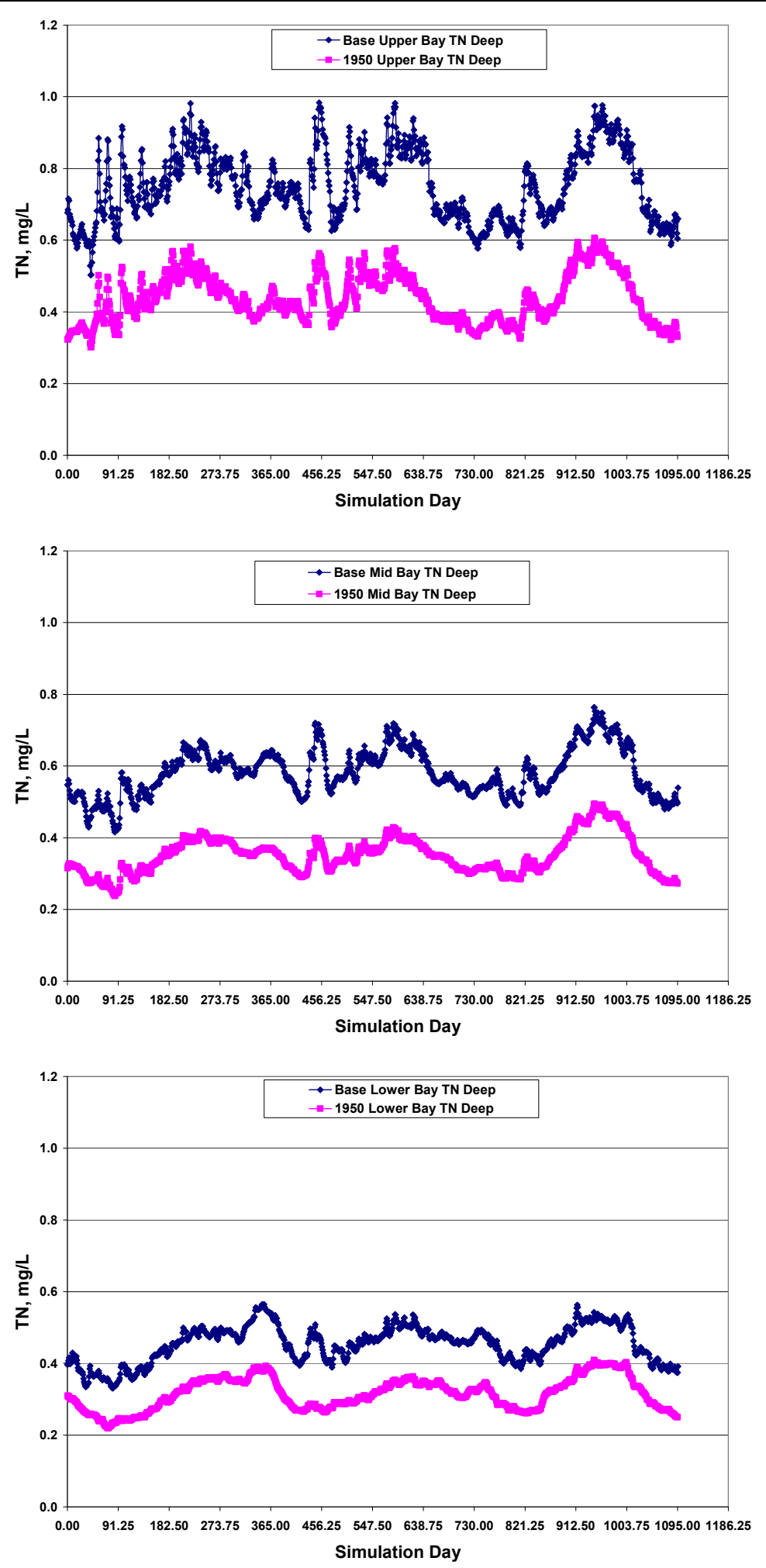

Figure 21. Comparison of the deep TN for base and 1950's RMB2 results in the upper, mid, and lower regions of the Chesapeake Bay. 


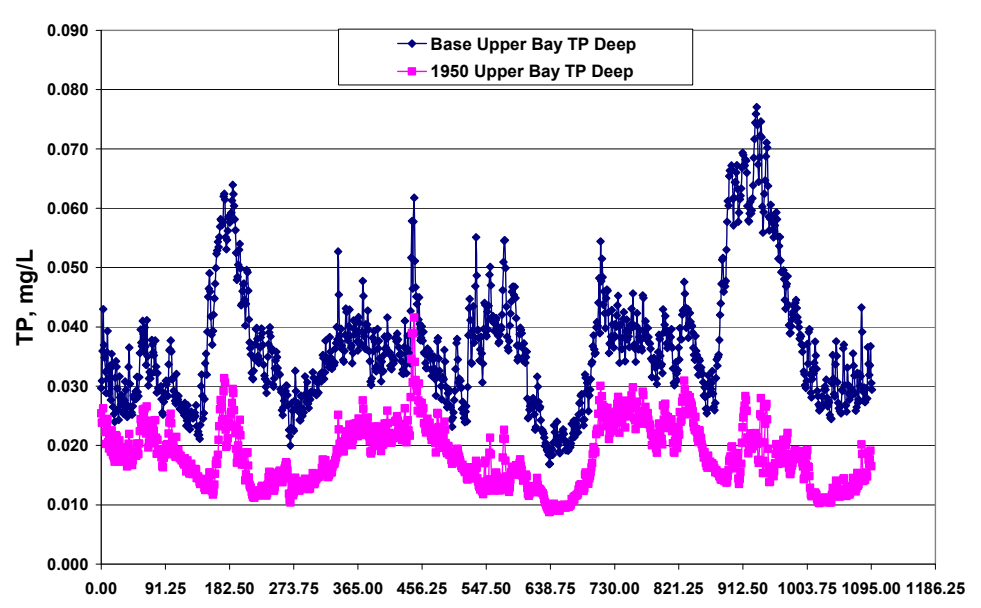

Simulation Day

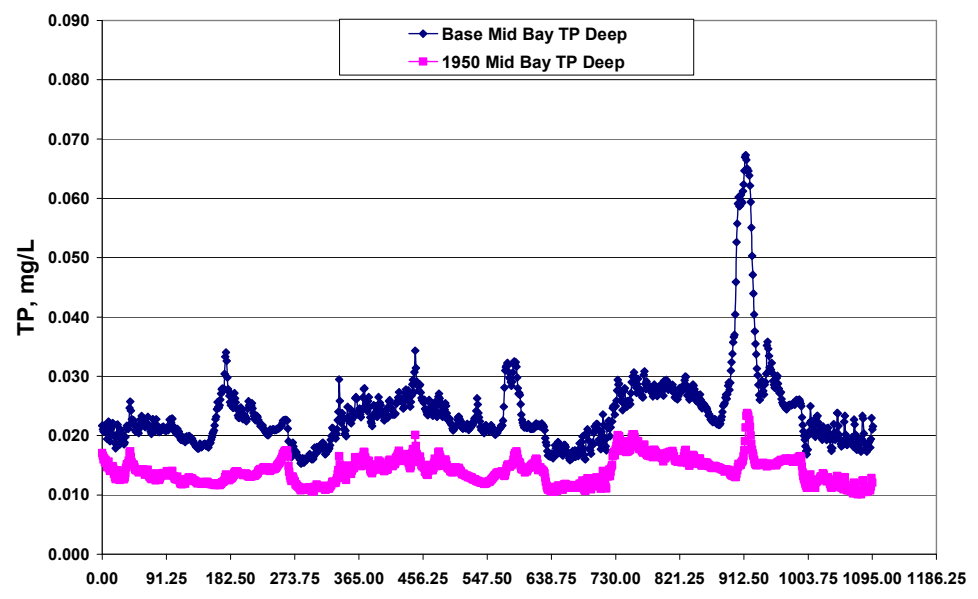

Simulation Day

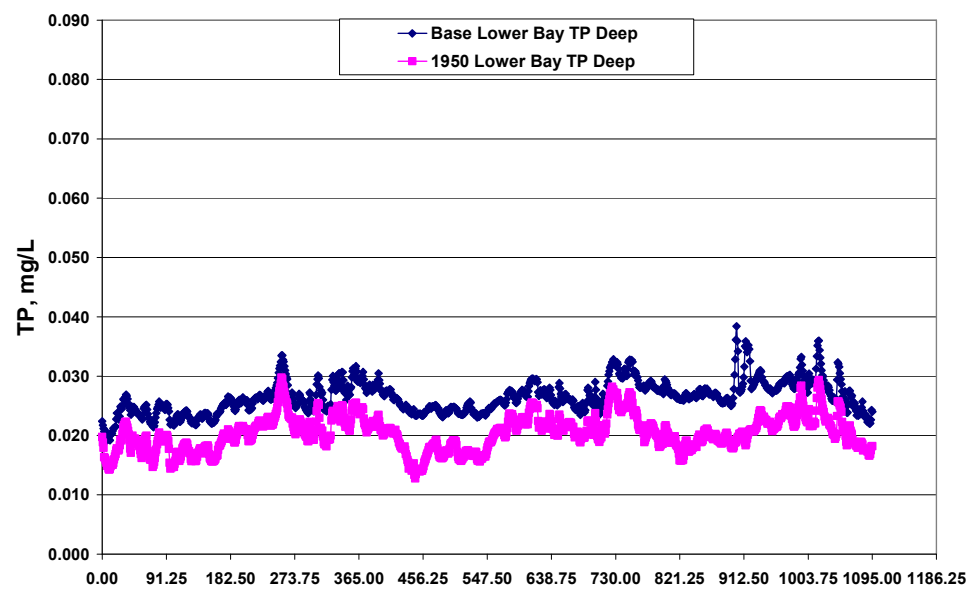

Simulation Day

Figure 22. Comparison of the deep TP for base and 1950's RMB2 results in the upper, mid, and lower regions of the Chesapeake Bay. 


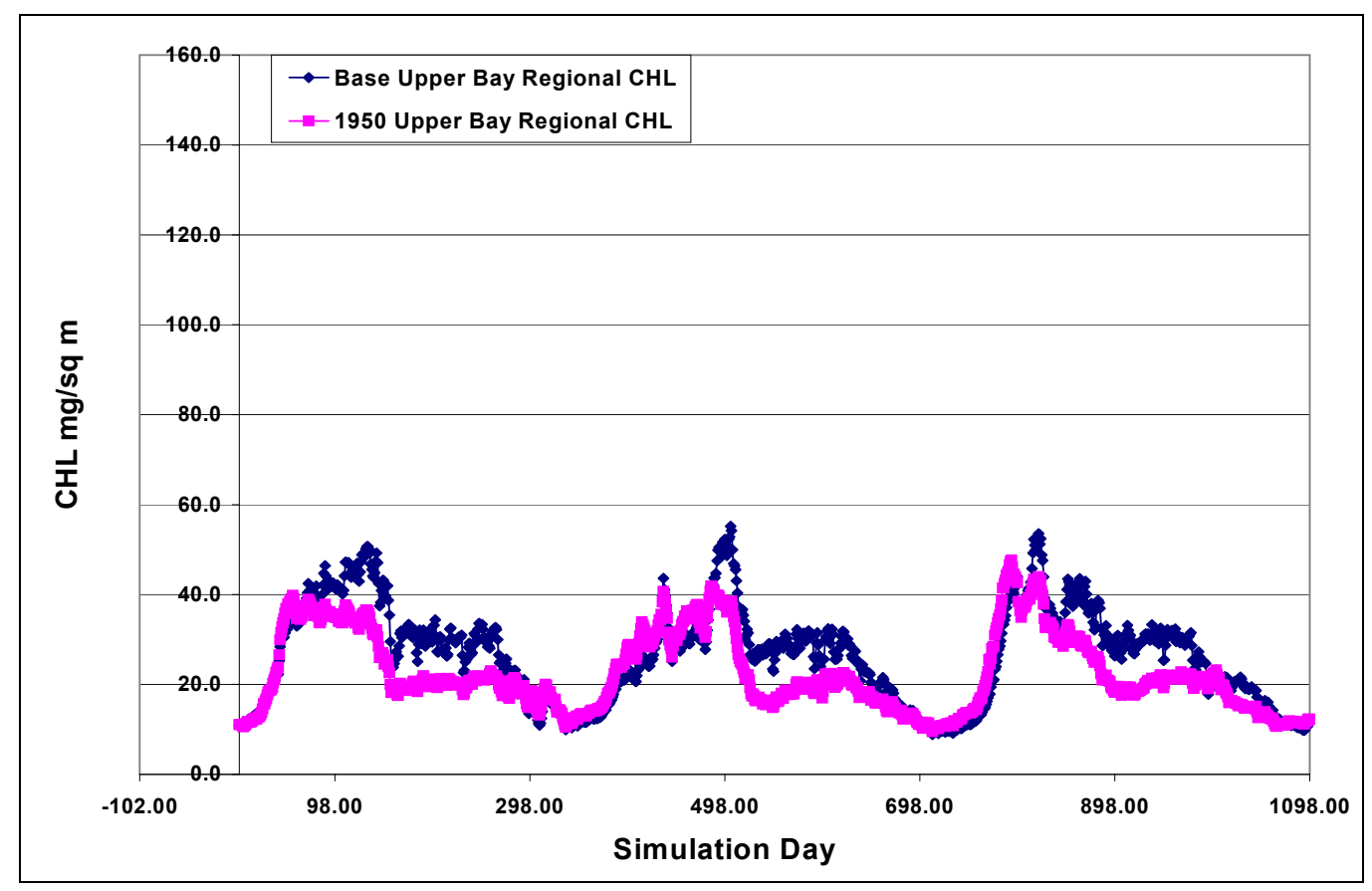

Figure 23. Areal concentrations of chlorophyll a for the upper Chesapeake Bay for base and 1950s RMB2.

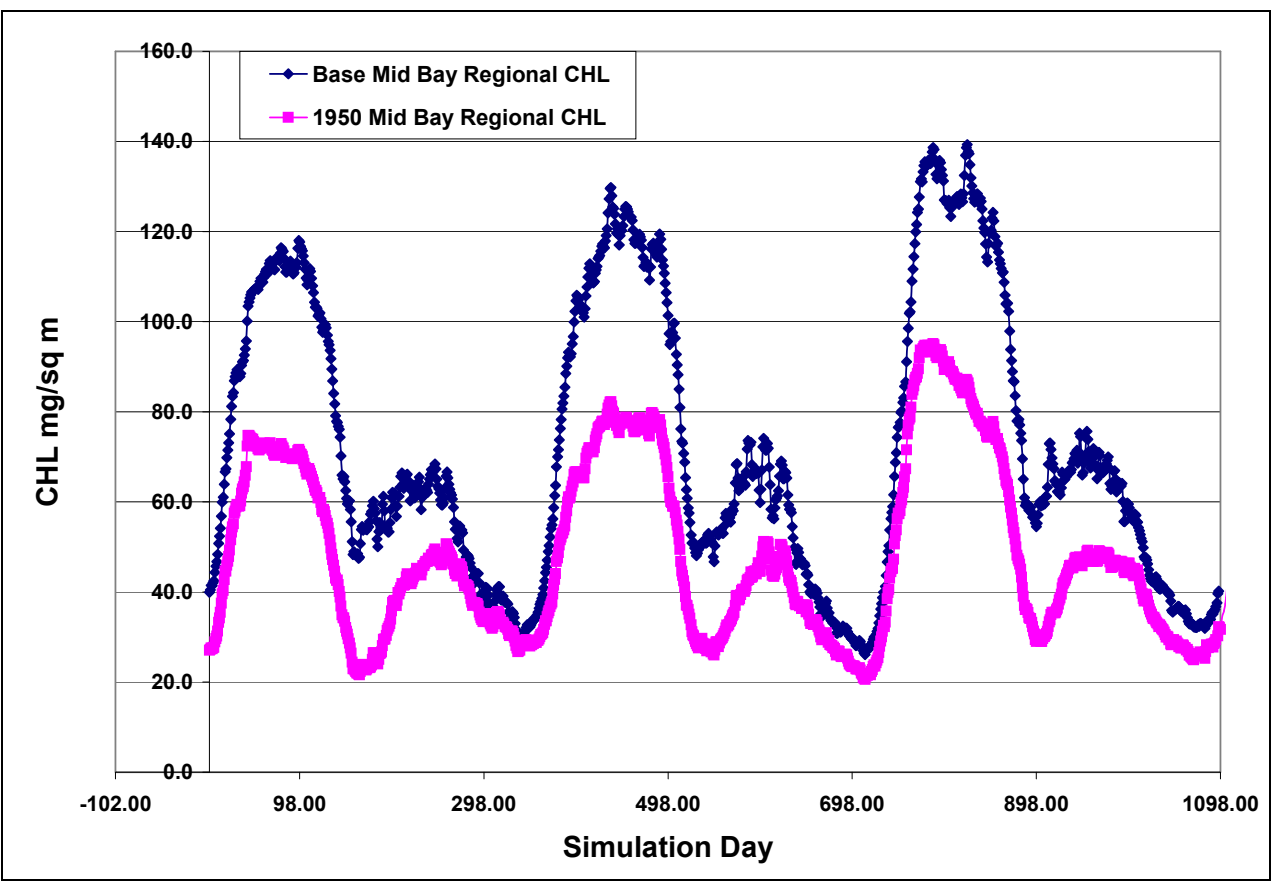

Figure 24. Areal concentrations of chlorophyll a for the mid Chesapeake Bay for base and 1950's RMB2. 


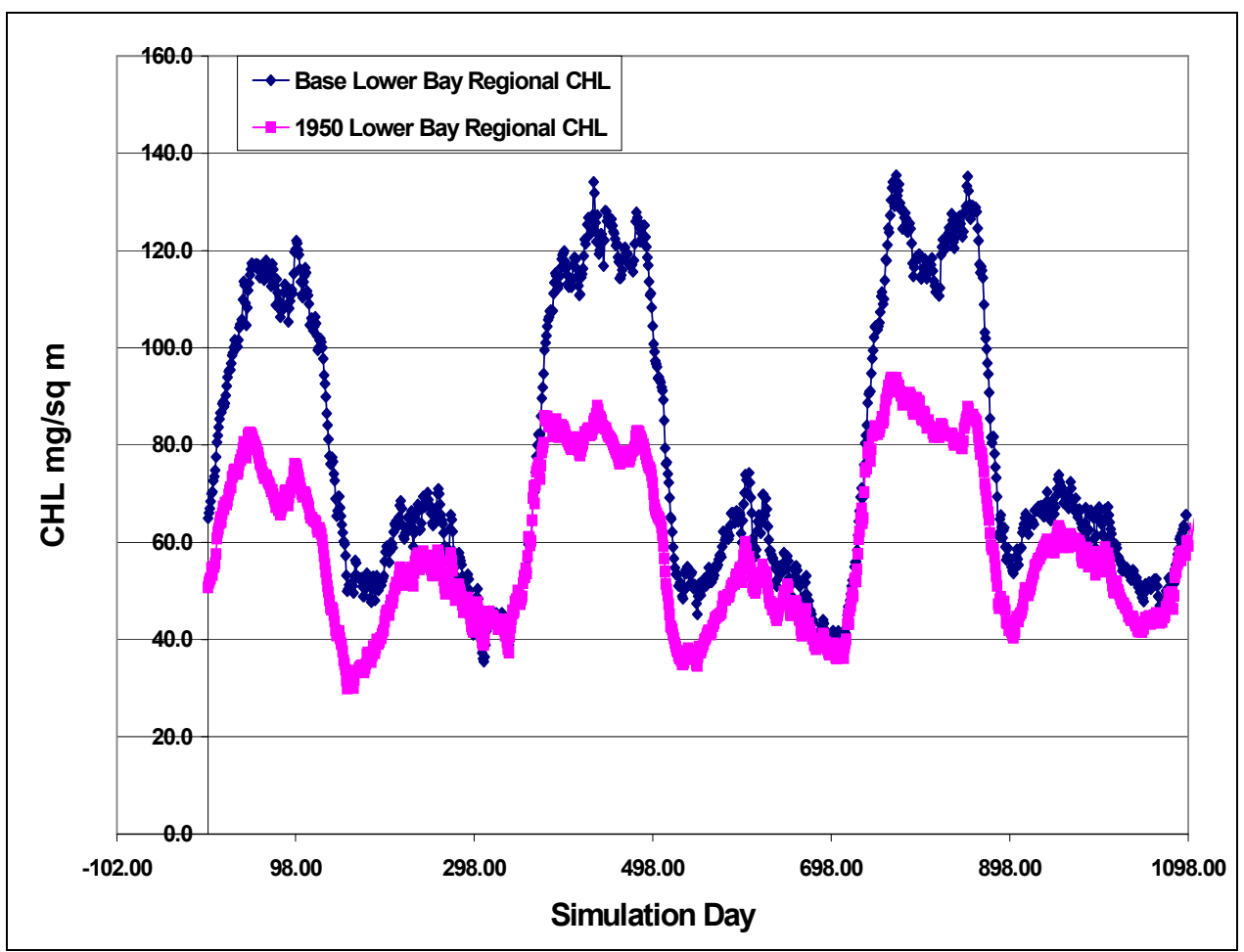

Figure 25. Areal concentrations of chlorophyll a for the lower Chesapeake Bay for base and 1950s RMB2.

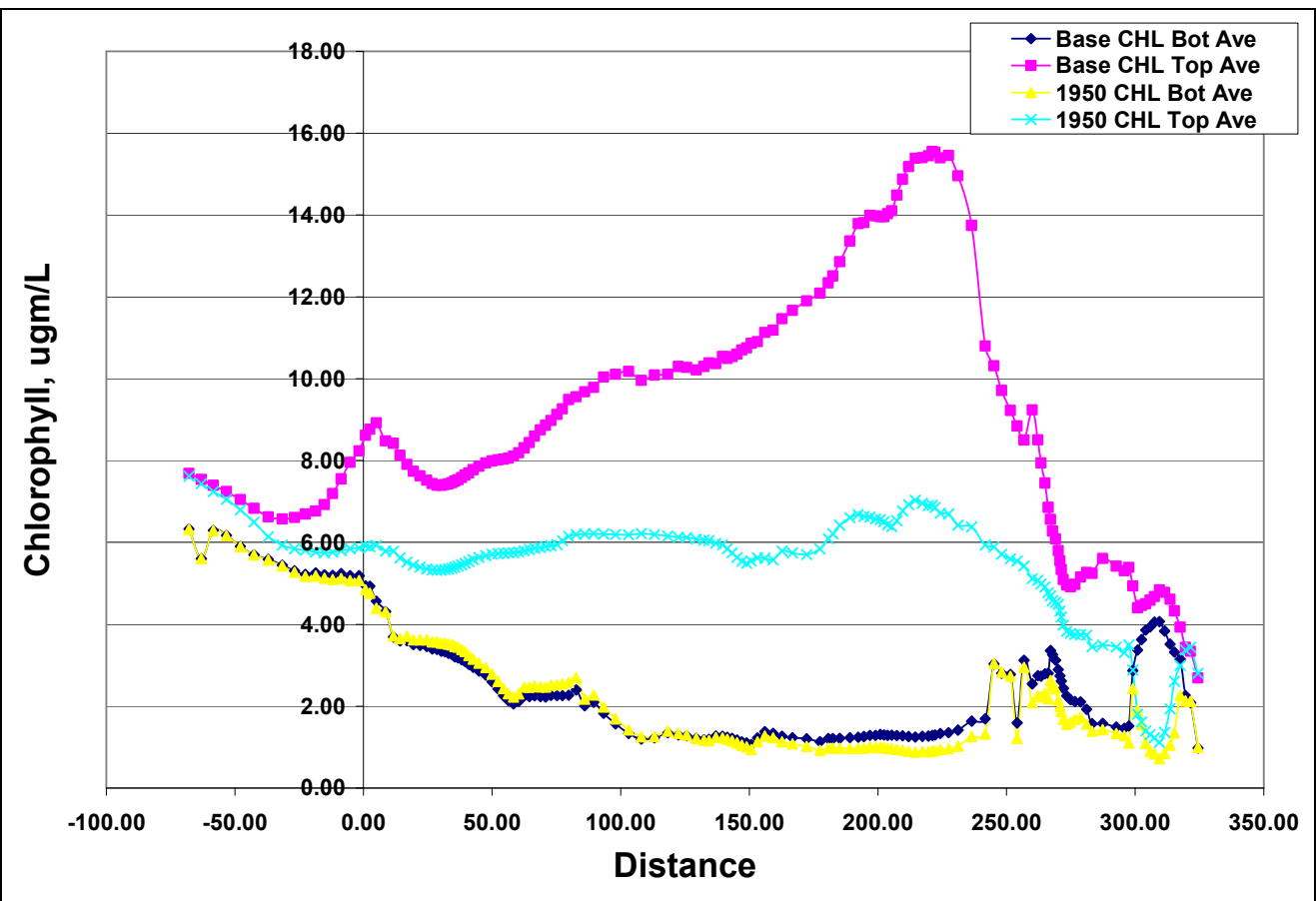

Figure 26. Comparison of summer averaged (1985-1987) chlorophyll a results longitudinally from the Susquehanna River $(\approx 325 \mathrm{~km})$ to the open ocean $(\approx-70 \mathrm{~km})$. 


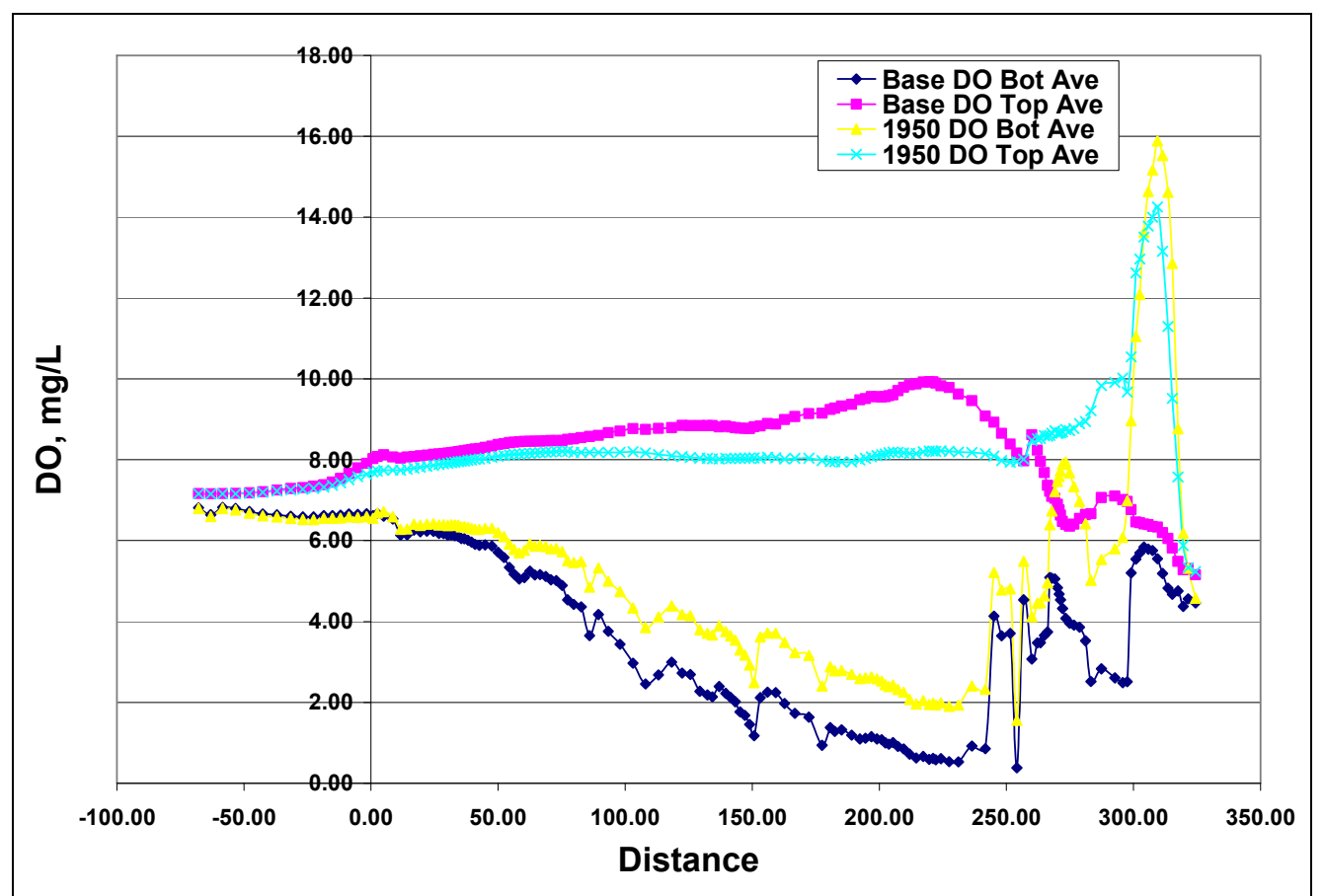

Figure 27. Comparison of summer averaged (1985-1987) DO results longitudinally from the Susquehanna River $(\approx 325 \mathrm{~km})$ to the open ocean $(\approx-70 \mathrm{~km})$.

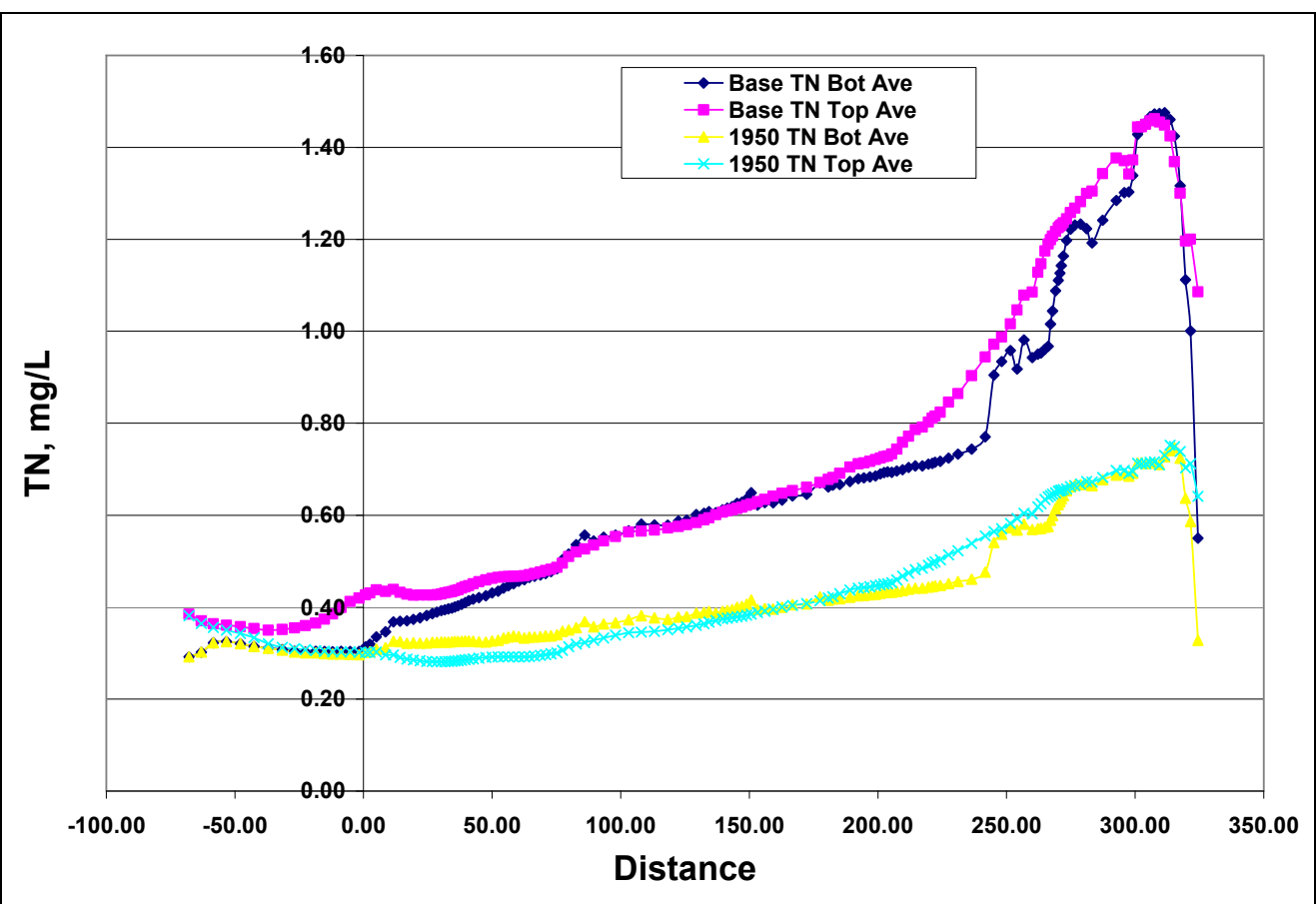

Figure 28. Comparison of summer averaged (1985-1987) TN results longitudinally from the Susquehanna River $(\approx 325 \mathrm{~km})$ to the open ocean $(\approx-70 \mathrm{~km})$. 


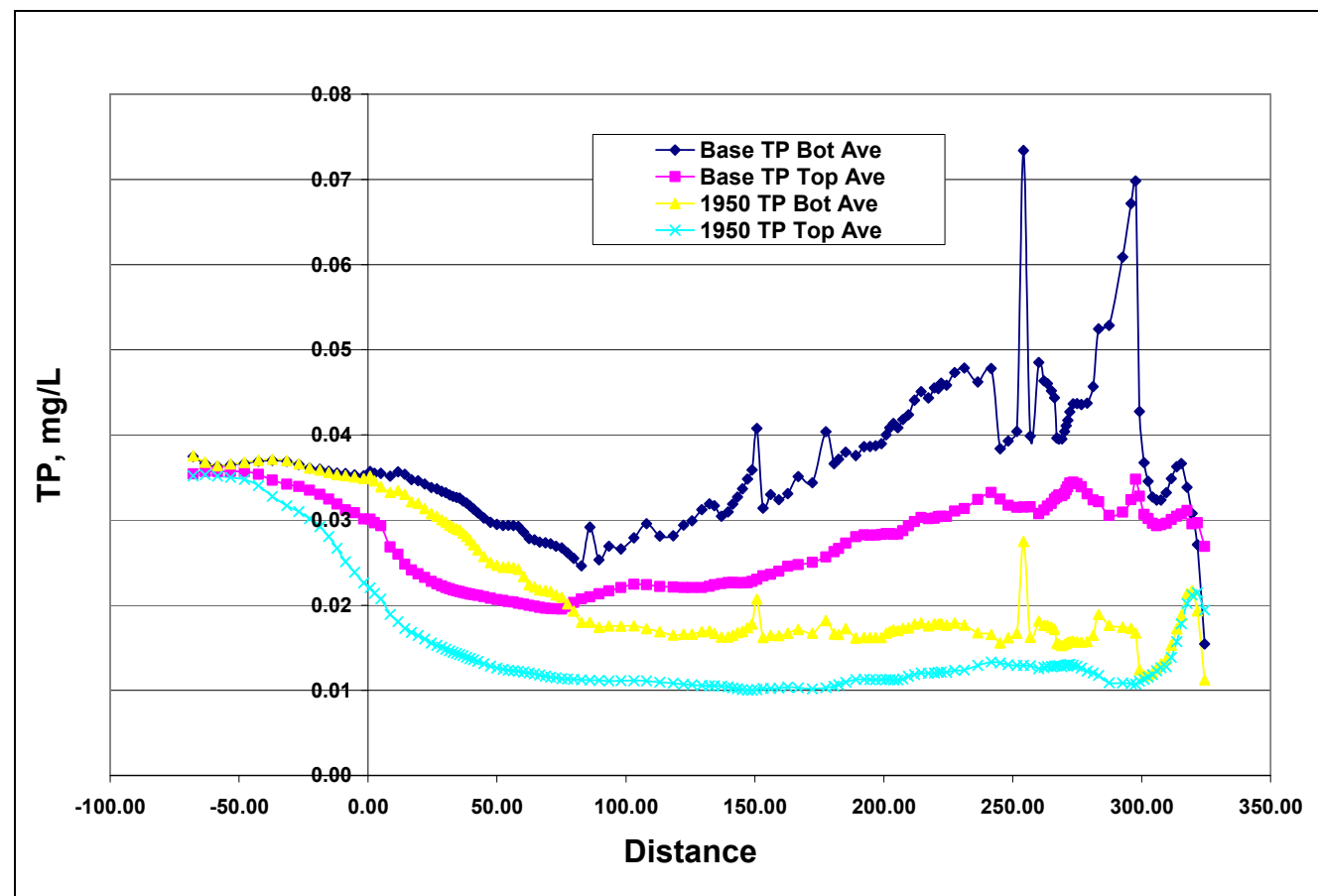

Figure 29. Comparison of summer averaged (1985-1987) TP results longitudinally from the Susquehanna River $(\approx 325 \mathrm{~km})$ to the open ocean $(\approx-70 \mathrm{~km})$.

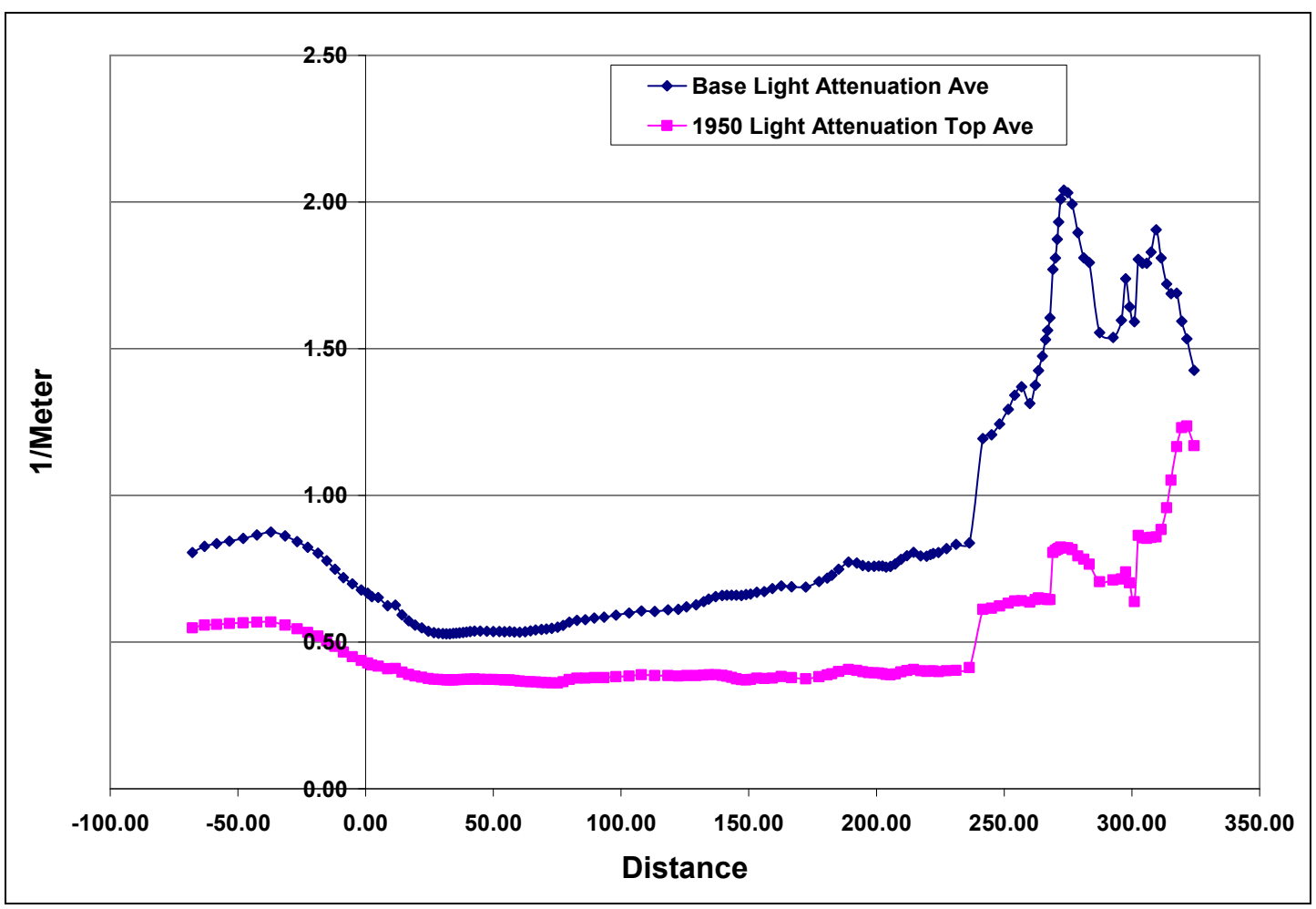

Figure 30. Comparison of summer averaged (1985-1987) light extinction results longitudinally from the Susquehanna River $(\approx 325 \mathrm{~km})$ to the open ocean $(\approx-70 \mathrm{~km})$. 


\section{DO volume-day plots}

Plots presenting anoxia and hypoxia in the three regions of the Chesapeake Bay (Figure 31) were plotted for the simulation period (1985 to 1987) and are shown in Figures 32 through 34. Two lines on each plot symbolize predictions from the base and 1950s restored mid Bay runs. Each line contains symbols that denote the 30-day average of DO for a specific DO interval. Four DO intervals were analyzed:

- DO values $0.1 \mathrm{mg} / \mathrm{L}$ or $<$

- DO values $1 \mathrm{mg} / \mathrm{L}$ or $<$

- DO values $2 \mathrm{mg} / \mathrm{L}$ or $<$

- DO values $5 \mathrm{mg} / \mathrm{L}$ or $<$

The statistic to calculate the DO volume-day came from Cerco and Cole (1994) and is defined as:

$$
D O V=\sum_{i=1, j=1}^{n, m} V_{i} \Delta t_{j} \quad \text { if } D O \leq \text { interval }
$$

where:

$$
\begin{aligned}
D O V & =\text { volume-day for interval }\left(\mathrm{m}^{3}\right. \text { day) } \\
n & =\text { number of model cells in a region } \\
m & =\text { number of time steps during the averaging period } \\
V i & =\text { volume of model cell }\left(\mathrm{m}^{3}\right) \\
\Delta t_{j} & =\text { finite-difference integration time step (day) } \\
D O & =\text { dissolved oxygen concentration }\left(\mathrm{gm} \mathrm{m}^{-3}\right) .
\end{aligned}
$$




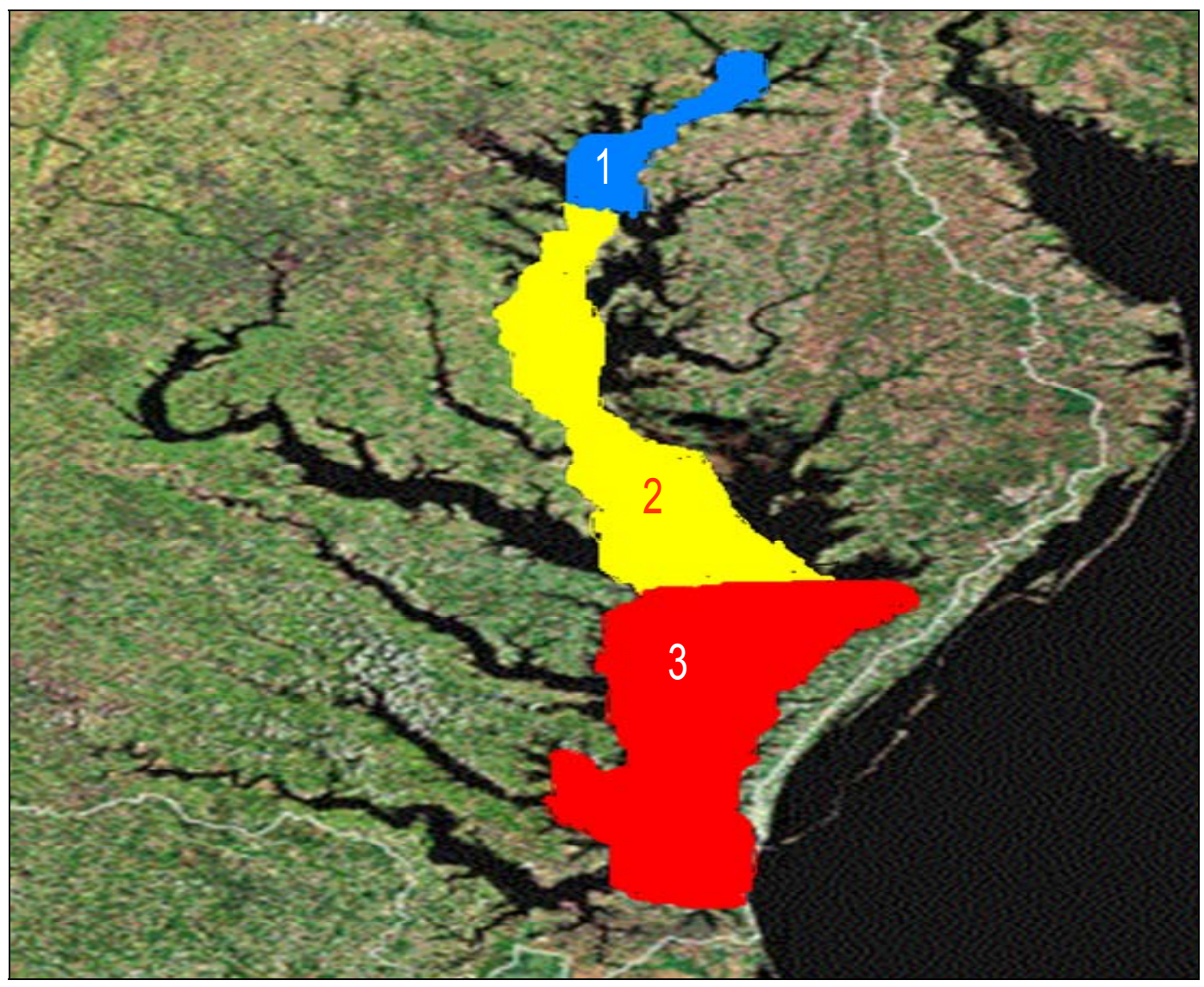

Figure 31. Three regions of Chesapeake Bay.

\section{Results and discussion}

Results will be presented for the ICM base run representing the modern mid bay to the 1950 s restored Bay run. This was an attempt to try and recreate the more pristine conditions that existed in the Bay at one time. By changing nutrients, light attenuation, and/or patchiness of the SAVs, will the Bay recover?

\section{Base versus sensitivity runs}

Model output will be presented in several graphical formats for the base and sensitivity runs. 


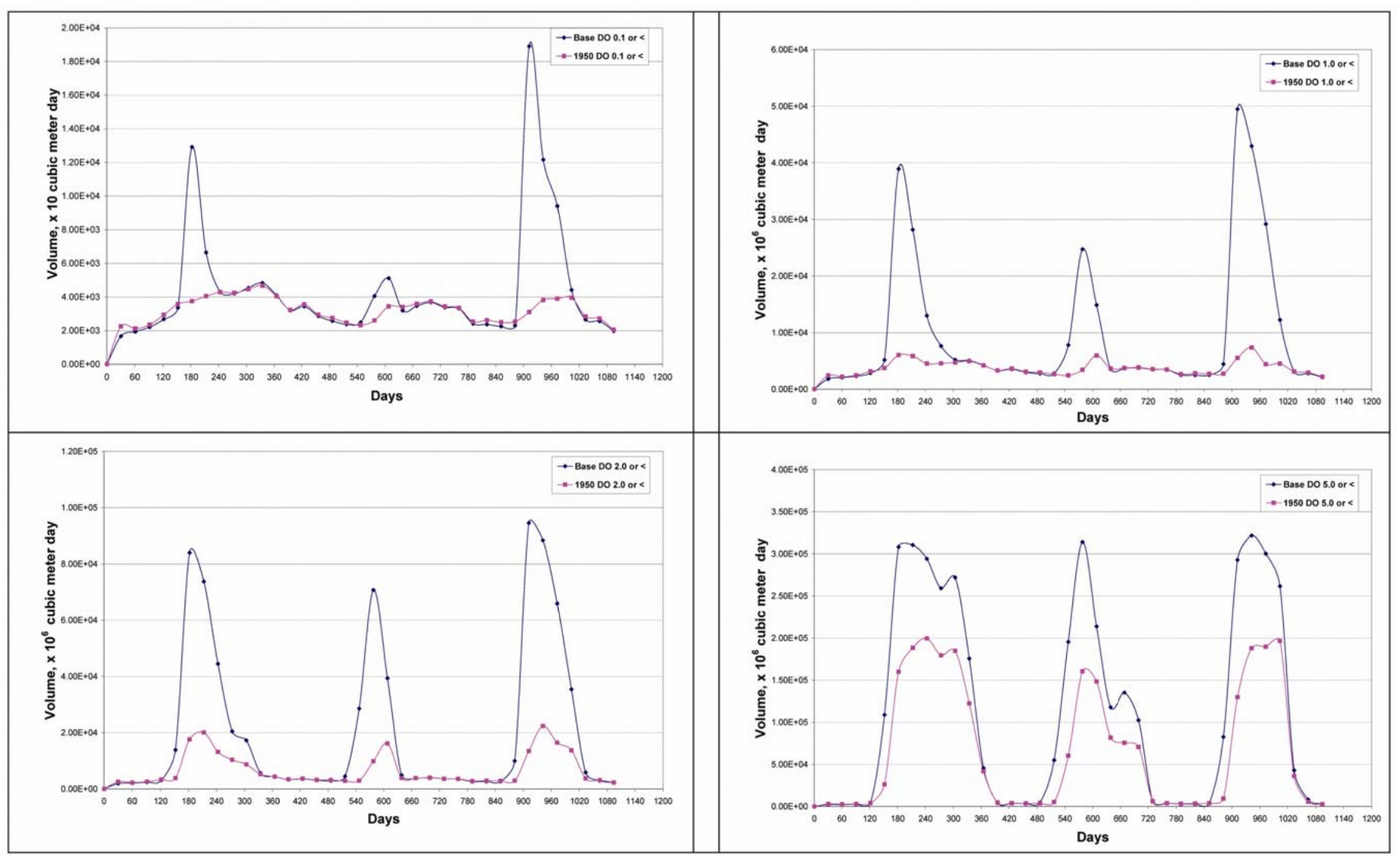

Figure 32. DO volume day for mid Chesapeake Bay region DO $\leq 0.1 ., 1.0,2.0$, and 5.0. 


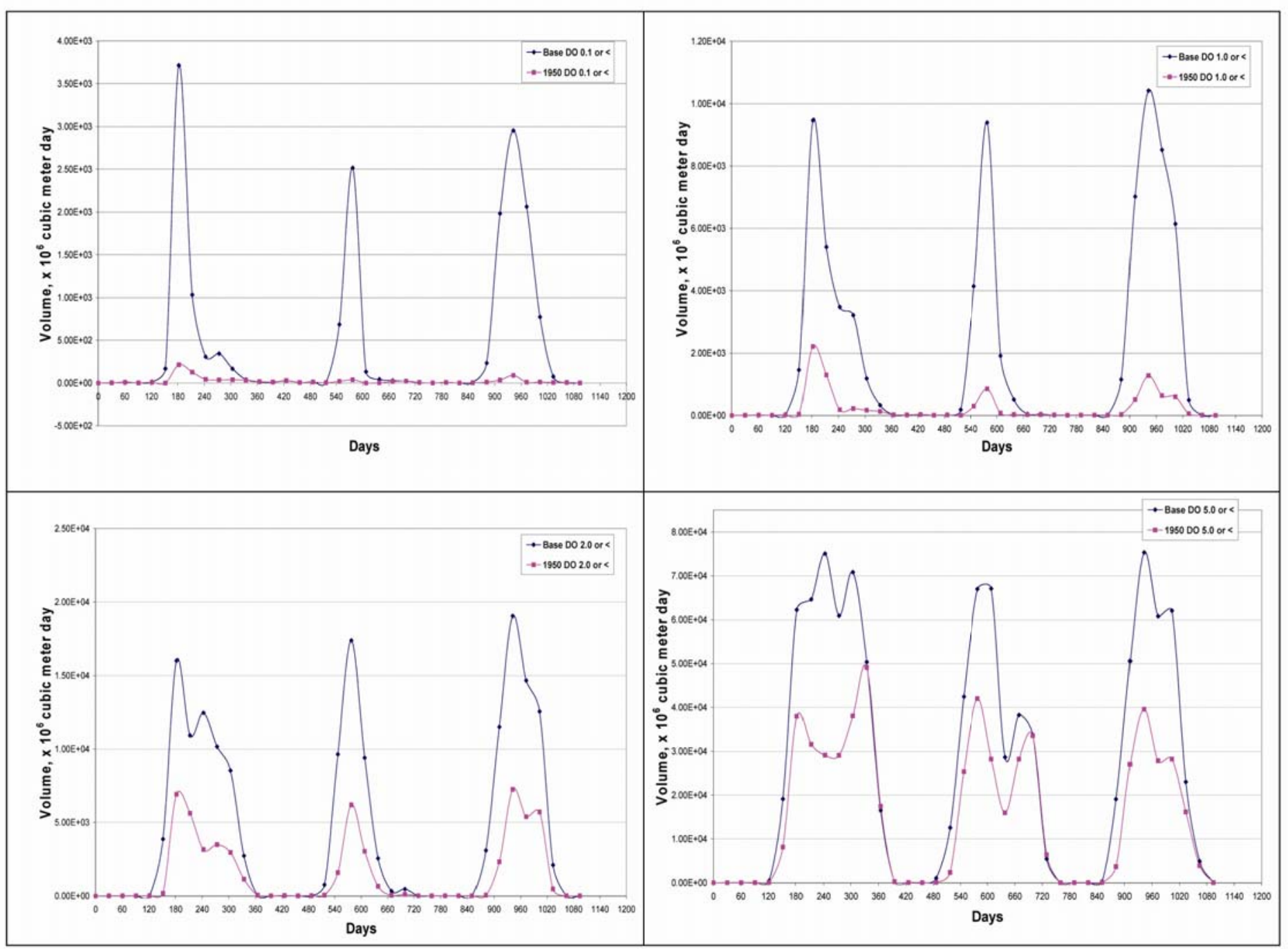

Figure 33. DO volume day for upper Chesapeake Bay region for $\mathrm{DO} \leq 0.1 ., 1.0,2.0$, and 5.0. 


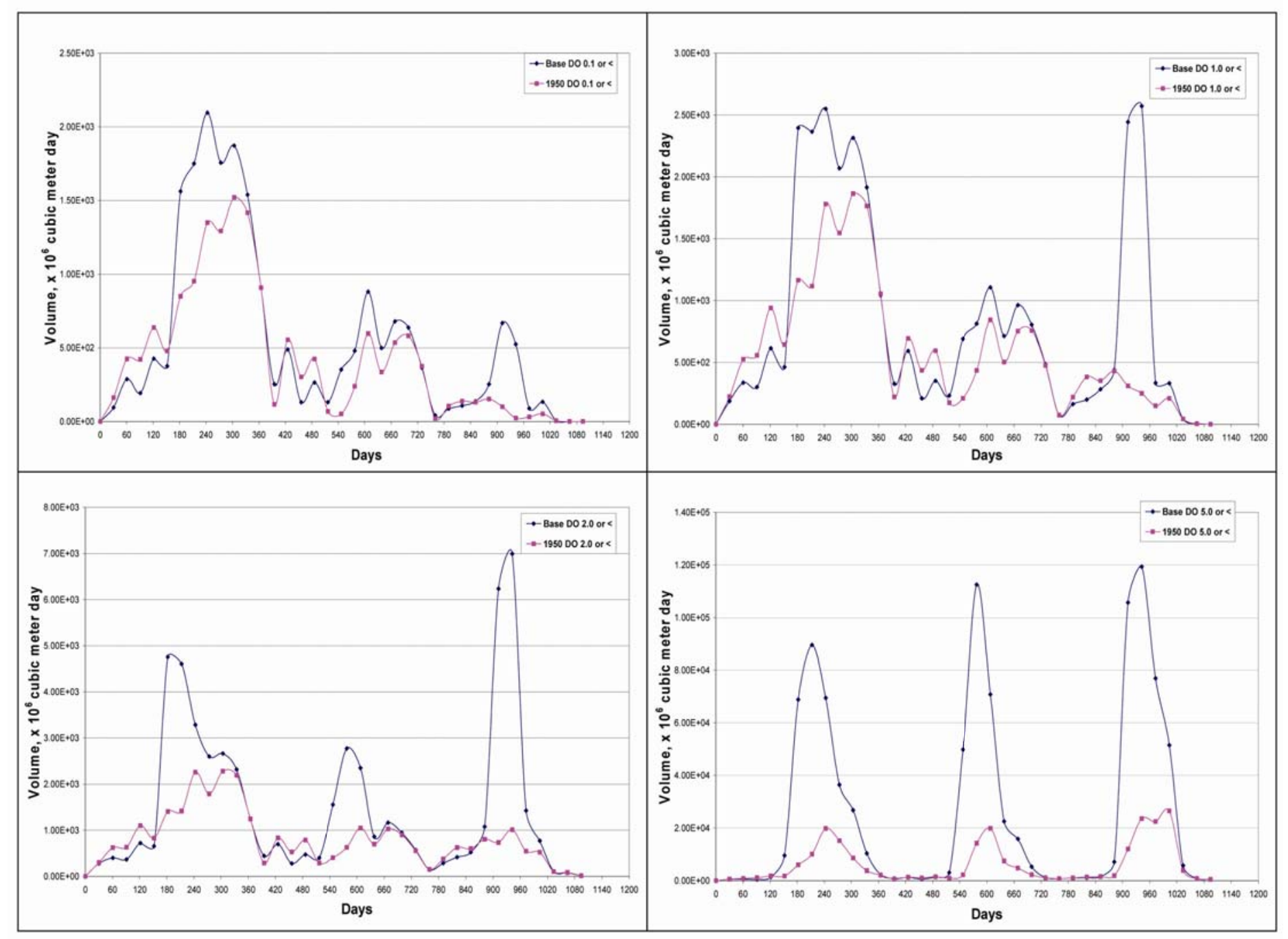

Figure 34. DO volume day for lower Chesapeake Bay region DO $\leq 0.1 ., 1.0,2.0$, and 5.0. 
Histograms of CE-QUAL-ICM to Ecopath parameters: Biomass, $P / B$ ratio, $Q / B$ ratio, and $U A / B$ ratio

Unquestionably, the most responsive indicator of nutrient enrichment $(\mathrm{N}$ and $\mathrm{P}$ ) in the Chesapeake Bay or anywhere is chlorophyll $a$ expressed as phytoplankton biomass (Harding and Perry 1997). From the 1950s to the 1990s, Harding and Perry (1997) show an approximate two-fold increase for chlorophyll $a$ in the mid Bay. Boynton el at. (1995) estimated increases of TN and TP loadings to be six-fold to eight-fold and thirteen-fold to twenty three-fold, respectively, since pre-colonial times. However, since the 1970s, TP loadings have been greatly reduced. With this in mind, reducing the external nutrient ( $\mathrm{N}$ and $\mathrm{P}$ ) loads 50 percent coming from the watershed causes reduction in the phytoplankton biomass by approximately 24 percent when compared to base results (Figure 6). This does not produce a two-fold decrease in phytoplankton biomass as might be expected. Moreover, this implies that there is not a one-to-one correspondence of reducing loads by 50 percent to get reduced biomass of 50 percent. As is the norm in any natural water body system, other factors influence phytoplankton biomass besides the external loads entering the system from the watershed. Boynton et al. (1995) include sediment nutrient fluxes and atmospheric loads (above and below hydrologic falllines) in their conceptual model of the Chesapeake Bay nutrient budget, as well as diffuse source and point source loads from the watershed. Another consideration here is the type of flow years used in the simulation. Harding and Perry (1997) suggest that the strong correlation between nutrient input and freshwater flow may cloud the issue of whether phytoplankton biomass increase or decrease is due to eutrophication or climate conditions. Chlorophyll a and primary production (PP) of the Chesapeake Bay have been shown to be strongly influenced by the flow from the Susquehanna River, which delivers approximately 60 percent of the freshwater flow to the Bay (Malone et al. 1988; Harding 1994).

In the SR2, both nutrient loads and $\mathrm{Ke}$ are reduced 50 percent, but there is only a slight additional decrease (i.e., 3 percent more) in phytoplankton biomass from the SR1. Decreased light attenuation could be considered equivalent to improvement in water clarity. Thus, it would be expected for the phytoplankton biomass to increase somewhat since more light is reaching deeper in the water column. However, it appears the benthic algae are utilizing more of the nutrients before the phytoplankton in the water column have access to it. Figure 6 shows definite increases when 
comparing the benthic algal biomass in both sensitivity runs to base results.

From Figure 7, the P/B ratio for phytoplankton and benthic algae follows the same trend as biomass when compared to base results. As biomass is reduced for phytoplankton, the $\mathrm{P} / \mathrm{B}$ ratio is reduced, and as biomass is increased for benthic algae, the $\mathrm{P} / \mathrm{B}$ ratio also increases. According to Kemp et al. (2005), increases in phytoplankton production and biomass have been related to decreased water clarity and growth of benthic diatoms as a direct result of nutrient enrichment. Conversely, through nutrient reduction, is it not conceivable to possibly create a shift in community production back to benthic algae having a greater role in the primary production of the Chesapeake Bay system? Increased benthic algal biomasses presented in Figure 6 appear to support this postulation.

Zooplankton are represented by two groups in CE-QUAL-ICM (microzooplankton and mesozooplankton). Figures 6 and 7 show that biomass and $\mathrm{P} / \mathrm{B}$ ratio results for both groups were reduced in the SR1 compared to base results. As discussed previously, CE-QUAL-ICM model formulation allows microzooplankton to graze on phytoplankton and DOC, while mesozooplankton are allowed equal weighting factors for grazing on phytoplankton and microzooplankton. Consequently, decreased phytoplankton and dissolved organic carbon (DOC) biomass affect zooplankton grazing since food source availability becomes an issue. With phytoplankton biomass being at least an order of magnitude greater than microzooplankton, microzooplanktons are essentially absent from mesozooplankton diet (Cerco and Tillman 2008). Mesozooplankton results from the SR2 follow the behavior seen in the SR1 (Figures 6 and 7) in that their biomass and $\mathrm{P} / \mathrm{B}$ ratio are both reduced. This is not the case for the microzooplankton. Their biomass actually increases slightly in the $\mathrm{SR} 2$, probably as a result of less predation from mesozooplankton. On the other hand, their P/B ratio remains similar to the value from the SR1 and by formulation, this would still indicate increased production. Cerco and Noel (2004) have suggested that the temperature function governing zooplankton grazing be revisited to allow more grazing at temperatures above $25^{\circ} \mathrm{C}$. Heinle (1966) has noted from feeding and bioenergetics studies that zooplankton growth is not usually limited by food. Their abundance and production can be affected by overabundance of nutrients through changes in their habitat (i.e., increases in bottom water hypoxia). 
Comparison of the $\mathrm{Q} / \mathrm{B}$ ratio response of both zooplankton groups (Figure 8) of SR1 results to the base results follows the trend of their P/B ratio response. As food sources of microzooplankton and mesozooplankton are diminished, a 10-percent and 18-percent reduction of the $\mathrm{Q} / \mathrm{B}$ ratio (consumption rate) is observed, respectively. SR2 results compared to SR1 results did not show a noticeable decrease in the Q/B ratio for microzooplankton simply because there was very little change in the consumption rate and biomass, but the $\mathrm{Q} / \mathrm{B}$ ratio of mesozooplankton was further decreased an additional 4 percent from the SR1 results. Again this was attributed to the decrease in biomass of food sources. The Q/B ratio could increase with decreased biomass only if the consumption rate has increased. That is possible if grazing by a predator is as fast or faster than growth.

There is very little or no change for the UA/Q ratio (the unassimilated food to consumption) in comparison of base results to SR1 and SR2 results (Figure 9). Unassimulated food is usually considered the by-product of urea and feces. The only group experiencing a noticeable change is suspension feeders.

\section{Time series of nutrient limitation in the mid Bay}

There is a consensus among many scientists that the limiting factors affecting phytoplankton growth are strongly influenced by temporal and spatial variations in the Chesapeake Bay (Kemp et al. 2005). Fisher et al. (1988) substantiate this observation by showing that both $\mathrm{N}$ and $\mathrm{P}$ limit phytoplankton growth during different seasons and at different locations within the Chesapeake Bay. The upper/oligohaline (0.5-5 percent salinity) regions of the Chesapeake Bay exhibit $\mathrm{P}$ and $\mathrm{Si}$ limitation at times through the year while the mid/mesohaline (5-18 percent salinity) and the lower/polyhaline (18-27 percent salinity) regions are most susceptible to $\mathrm{N}$ limitation for phytoplankton growth (Harding and Perry 1997). The Chesapeake Bay exhibits a two-phase annual cycle of phytoplankton production (Adolf et al. 2006; Conley and Malone 1992) with increased production in the spring (April-May timeframe) resulting from freshwater riverine nutrient loads and a summer maximum supported by regeneration of nutrients from the sediments. With this in mind, analyses of nutrient limitation for all primary producer groups, not just phytoplankton in the mid Bay, were considered for both sensitivity runs. 
Figure 3 corroborates for the base results at least for summer periods (June 1 through August 31) in the mid Bay what has been noted previously for phytoplankton growth limitation - phytoplankton growth is limited by $\mathrm{N}$ or co-limited by $\mathrm{N}$ and $\mathrm{P}$ in the summer and is limited by $\mathrm{P}$ the rest of the year (see Figure 16 from Kemp et al. (2005)). In early March of all years simulated, there are small dips in silica ( $\mathrm{Si}$ ) limitation with results from the third year (1987) showing Si and P co-limiting for a short period of time. This probably corresponds to diatom spring bloom dynamics and Si uptake. Sellner and Brownlee (1988) estimate the composition of algal abundance in the spring as being composed of 80 to 90 percent diatoms. Moreover, spring limitation of diatoms by Si has been noted by Conley and Malone (1992). They agree that Si limitation may be an important factor in reducing the spring algal biomass maximum and go on to infer that this could have important implications for nutrient management strategies.

When nutrient loads ( $\mathrm{N}$ and $\mathrm{P}$ ) are reduced 50 percent in SR1, summer periods of $\mathrm{N}$ and $\mathrm{P}$ co-limitation become more pronounced (Figure 3) with the Chesapeake Bay system becoming more $\mathrm{N}$ limited at times. Another difference noted from base results is the extended duration of limiting conditions for both $\mathrm{N}$ and $\mathrm{P}$. As discussed previously, phytoplankton biomass was reduced but not by the same percentage as nutrients. Consequently, the phytoplankton groups are demanding more nutrients, increasing the $\mathrm{N}$ and $\mathrm{P}$ limitations during prime growth periods. Nutrient reduction has affected $\mathrm{Si}$ limitation opposite of $\mathrm{N}$ and $\mathrm{P}$. The dips in $\mathrm{Si}$ limitation noticeable in the base results during early spring are barely visible. This indicates that the phytoplankton group feeding on Si has been reduced to the point that it is no longer in as much demand.

From Figure 3, results from the SR2 show it is clearly evident that the mid Chesapeake Bay is more $\mathrm{P}$ limited than either of the previous runs. Before, $\mathrm{P}$ and $\mathrm{N}$ shared the role as limiting nutrients at certain times of the year with $\mathrm{P}$ being the limiting nutrient during the rest of the year, but this is not the case for this run. The major difference between this run and the other two is that the SAV group and not just the benthic algae group has increased in biomass (Figure 6). This implies that through nutrient reduction and reduced turbidity, SAV and benthic algae have increased growth thus adding to the production of the system. This is consistent (at least for SAVs) with other field and modeling studies that identified improved water clarity and reduced nutrients as means to recover SAV beds (Kemp et al. 2005). $\mathrm{N}$ and Si limitation followed similar trends as 
observed in the SR1. N limitation followed the same pattern but the range of limitation is not as pronounced (i.e., a most limiting value of 0.46 compared to 0.28). Si limitation values looked almost identical to these results, leading to the same conclusion presented previously about the phytoplankton group.

Limitations for benthic algae from the comparison of the base with SR1 results denoted slight decreases to $\mathrm{N}$ and $\mathrm{P}$ limitation values, although the trends through the years were similar (Figure 4). This was attributed to the increase in benthic algal biomass and production resulting from nutrient load reduction. Either from less phytoplankton demand (i.e., decreased biomass) or benthic algae having uptaken nutrients first, $\mathrm{N}$ and $\mathrm{P}$ became more limiting than they normally would be. Nevertheless, light limitation still remained the limiting factor for both of these runs. With the addition of reduced light attenuation, results from SR2, when compared to the two previous runs, show a remarkable change to $P$ limitation. As illustrated in Figure 4 for the early to late winter periods in all years modeled, $P$ and light became co-limiting factors. This probably corresponds to winter diatom algal blooms.

Patterns of limiting variables of SAV for the two sensitivity runs showed the smallest change from base results than exhibited for the other two primary producers. There is consensus (Cooper and Brush 1993; Davis 1985; Orth and Moore 1983) that light is the main limiting variable for SAV, and this is demonstrated for all runs conducted. Results show a cyclic pattern of light being less limiting in the winter to more limiting in the summer. SR1 with nutrient load reduction produced minimal change to the light limitation with slightly more change to P limitation; $\mathrm{N}$ limitation actually became less limiting. In terms of production, SAV biomasses were reduced but $\mathrm{P} / \mathrm{B}$ ratio actually showed an increase implying an increased production rate. Since production of SAV in CEQUAL-ICM is dependent on light, it is possible to see increased production rate with decreased biomass. Results from SR2 show SAV biomass and $\mathrm{P} / \mathrm{B}$ ratio have increased, causing slightly more $\mathrm{P}$ limitation resulting in the winter period. As with benthic algae, $\mathrm{P}$ and light co-limit growth during this period with light limitation being the limiting factor the rest of the time. N limitation does not appear to play any role in SAV growth. 


\section{Base versus 1950's restored mid Bay run}

Histograms of CE-QUAL-ICM to Ecopath parameters: Biomass, $P / B$ ratio, $Q / B$ ratio, and $U A / B$ ratio

In Figure 6, biomass of the primary producers for the 1950's RMB1 compare similarly to results from the SR2 run next to base results. For the 1950's RMB1 and SR2 results, phytoplankton biomass decreases while biomasses of the other two groups increase similar amounts. Accordingly, their differences from base results are about the same. There is a plausible explanation for this. Specifically, the nutrient loads for both runs were reduced by similar amounts (e.g., 0.57 and 0.70, respectively, for 1950's RMB1 and 0.5 for both $\mathrm{N}$ and P for the SR2). At the time SR2 was conducted, the loads for the 1950's RMB1 had not been estimated so it was not known they would be so comparable. Based on this and the fact that the SAV biomass needed to be more in line with Hagy (2002), it was decided to adjust the patchiness coefficient to try to increase SAV biomass. This run was designated as the 1950's RMB2. By adjusting patchiness from 0.1 to 0.5 , SAV was allowed to grow in 50 percent of the cells modeled as SAV beds instead of 10 percent. By doing this, SAV biomass certainly increased although perhaps a bit too much (Figure 6). The P/B ratios of most groups modeled for the 1950's RMB2 were reduced from base except for benthic algae and SAV. Similar to the SR1 and SR2 results, the P/B ratio for all groups follows the same trend as biomass results compared to base results; as biomass is reduced for phytoplankton, zooplankton, deposit feeders, and suspension feeders, the $\mathrm{P} / \mathrm{B}$ ratio is reduced, and as biomass is increased for benthic algae and $\mathrm{SAV}$, the $\mathrm{P} / \mathrm{B}$ ratio also increased. Again this represents a reduction in production rate for all groups except benthic algae and SAV.

Comparison of the $\mathrm{Q} / \mathrm{B}$ ratio response of the zooplankton and benthos groups (Figure 8) from the 1950's RMB1 and the 1950's RMB2 to the base results follows trends similar to the $\mathrm{P} / \mathrm{B}$ ratio response. As food sources of microzooplankton and mesozooplankton are diminished, 10-percent and 28-percent reductions of the Q/B ratio are observed, respectively. Comparing the 1950s RMB1 to the 1950's RMB2 did not show a noticeable decrease in the Q/B ratio for microzooplankton possibly because: their food source biomass did not change a great deal, their consumption rate probably remained the same, and their biomass was not changed. Mesozooplankton $\mathrm{Q} / \mathrm{B}$ ratio did show a little more variation from one scenario to the next with the 1950's RMB2 showing a greater decrease from base 
than the 1950's RMB1. This could have resulted from decreased phytoplankton biomass, although the consumption rate between the two was not so different. The Q/B ratios for the deposit and suspension feeders show opposite behavior when compared to base results. In particular, deposit feeders have increased in biomass for both 1950's RMB1 and SR2 when compared to base results, although the $\mathrm{P} / \mathrm{B}$ ratio is less than base for both. Without a doubt, increased biomass is a direct result of increased benthic algae as well as sediment particulate organic carbon (POC). Both of these groups are allowed as food sources for the benthos in CE-QUALICM. Suspension feeder Q/B ratios show only slight changes from base to 1950's RMB1 and SR2 results even though their biomasses show significant differences from base. Consumption rates seem to vary only slightly among runs (i.e., 0.14 day $^{-1}$ for base, 0.135 day $^{-1}$ for 1950's RMB1, and 0.156 day $^{-1}$ for 1950's RMB2).

There is very little or no change for the UA/Q ratio in comparing base results to 1950's RMB1 and 1950's RMB2 results. Like the sensitivity scenario runs, the only group showing a noticeable change is the suspension feeders.

\section{Time series and longitudinal plots}

Concentrations of chlorophyll $a$ in the surface waters of each region (i.e., upper, mid, and lower denoted in Figure 10) demonstrate what has been observed by many scientists (Harding 1994; Harding and Perry 1997; Fisher et al. 1988): strong seasonal variation of chlorophyll $a$ with increased production in the spring and a second high productivity period in the summer driven by remnants of the spring bloom. This is observed in the pycnocline and deep layers of the Bay as well (Figures 10, 15, and 19). Comparing chlorophyll $a$ base results to the 1950s RMB2 results reveals a number of observations. First, although base results in the surface layer of the mid and lower bay are 30 to 50 percent higher during spring and summer production periods than 1950 O RMB2 results, there are no great differences in the upper Bay. This coincides with the two-fold increase reported by Harding and Perry (1997) for the increase in chlorophyll concentration from the 1950 os to present day. Additionally, winter concentrations between the two runs are quite similar. In a previous discussion, lower chlorophyll concentrations for the 1950s RMB2 are attributed to the reduction in nutrient loads; however, this does not eliminate the summer maxima from occurring in any of the regions indicating the regeneration of $\mathrm{N}$ and $\mathrm{P}$ from the spring blooms continue to 
support summer growth. Secondly, in the pycnocline and deep layers of the mid and lower Bay during spring and summer periods of high production, higher concentrations of chlorophyll $a$ occur in the base results (up to approximately 40 percent greater than 1950's RMB2 results). Upper Bay results for these layers show differences between the runs but are again less than what was observed for the other two regions. Chlorophyll $a$ concentrations in the pycnocline layer of the upper Bay show only small differences during the spring bloom. Differences are greater in the deep layer than in the pycnocline, but not near the range seen in the mid and lower Bay for these layers.

A longitudinal plot (Figure 26) of chlorophyll $a$ from the Susquehanna River confluence (distance $\approx 325 \mathrm{~km}$ on figure) to the ocean boundary (distance $\approx-50 \mathrm{~km}$ on figure) indicates the highest chlorophyll $a$ concentrations occur in the mid Bay region followed by the lower region. Kemp et al. (2005) have indicated this same chlorophyll $a$ trend throughout the Bay. Of the three regions, the mid Bay shows the most change in chlorophyll $a$ from base results when comparing the 1950s RMB2 results. This is probably related to freshwater in flows from the Susquehanna River and possibly regenerated nitrogen from spring blooms being depleted through the Bay as it flows to the mouth. Longitudinal $\mathrm{N}$ depletion can be seen in Figure 28 for the base and 1950s RMB runs. This is in agreement with Harding and Perry (1997) who have related the lower mesohaline and polyhaline chlorophyll $a$ concentrations to $\mathrm{N}$ supply and state that concentrations are mostly lower than those found in the more northern areas.

Regional plots of chlorophyll $a$ on an areal basis (mg/m2) show chlorophyll concentrations follow similar trends and patterns to chlorophyll $a$ observed in the surface layer (Figures 23-25). This may be because the surface layer encompasses more of the regional area weighting the estimated concentrations so that they look like what occurs in the surface layer more than the other.

Just as chlorophyll $a$ concentrations vary seasonally in the Chesapeake Bay, DO concentrations do the same. Plots of DO concentrations for all layers and regions (Figures 11, 16, and 20) show increased DO concentrations during the spring season corresponding to the spring diatom bloom. This is demonstrated in the base and 1950 os RMB2 runs. DO concentrations decrease until the lowest values occur in the early summer at 
all regions. This is initiated by organic matter decay from the spring algal bloom that lasts through the summer and begins recovery in the fall (Hagy et al. 2004). Equally important, results of the 1950s RMBf2 run show that shortly after the minima, DO concentrations in the upper Bay climb in concentration to a second maximum in concert with the summer algal bloom. This is most noticeable in the surface and pycnocline layers. Of the modifications made to conduct the 1950s RMB2 run, decreased light attenuation in all likelihood is what produced this behavior. DO concentrations approach anoxic conditions in the pycnocline of the upper Bay and the deep layer of the upper and mid Bay. Anoxic conditions do not form in the lower Bay because most of the organic matter has been depleted in the upper and mid Bay. Illustrating this fact, the longitudinal plots (Figure 27) of surface and bottom DO show that most of the anoxic/hypoxic water occurs between 140 and $255 \mathrm{~km}$ from the ocean boundary of the Bay. These observations have been documented by Cerco and Cole (1994).

Nutrient behavior through the Bay follows the same trend as chlorophyll $a$ and DO. This is seen in Figures 12, 13, 17, 18, 21, and 22 as N and P concentrations are highest in the upper Bay in the spring, show a period of decline in summer, rise again in the later summer, and decline to a minimum in the late autumn. This cycle is repeated in all years modeled. The high nutrient concentrations in the spring coincide with the spring freshet bringing nutrients from the watershed and in summer are from dead algal matter and sediment releases. Model predictions have produced similar findings by Adolf et al. (2006) and Harding et al. (2002) in that flora and algal community composition and primary productivity are highly influenced by the magnitude of the flows coming from the Susquehanna River which control the timing, spatial extent, and extent of the spring algal bloom through regulation of the light and nutrients. Spatially, Figures 28 and 29 illustrate this point as $\mathrm{N}$ and $\mathrm{P}$ concentrations are reduced as one moves down the Chesapeake Bay main longitudinal axis beginning at the confluence of the Susquehanna River to the Bay (distance $\approx 325 \mathrm{~km}$ ) and ending at the ocean boundary (distance $\approx 0.0 \mathrm{~km}$ ). Both runs show decreased nutrient concentrations with top and bottom concentration similar in value. Differences between run results are simply from load reduction for the 1950 os RBB2 run.

As seen for other constituents, light attenuation longitudinally decreases through the Bay (Figure 30) for the Base conditions and the 1950s. It is 
highest in the shallow upper Bay and remains fairly constant until it reaches the ocean. Because of the inflow from the Susquehanna River, the upper Bay receives higher total suspended solids than the mid and lower Bay, probably increasing the light attenuation in this area. Also this area is susceptible to spring algal blooms creating large amounts of suspended solids. Light attenuation values reported by Kemp et al. (2005) in the most saline area of the Patuxent River were in the range of $0.97 \mathrm{~m}^{-1}$ for the 1930 s and $1.38 \mathrm{~m}^{-1}$ for the 1990's. This area is comparable to values found in the Chesapeake, around $165 \mathrm{~km}$ in Figure 30. Although these same values do not occur at this location in the figure, the same trend of light extinction does occur, increasing from the 1950 os to the 1980 os. Also, Figures 35 through 37 illustrate measured secchi depth values (averaged from June through August) for segments of the upper (CB1, CB2, and $\mathrm{CB} 3$ ), mid (CB4 and $\mathrm{CB} 5$ ), and lower (CB6, CB7, and CB8) Chesapeake Bay over a 65 -year period. These data were provided by the EPA Chesapeake Bay Program. Each symbol on the figures represents a different segment (Figure 2) within the regions. Secchi depth measurements after 1983 were collected during the Chesapeake Bay Monitoring Program and are noted by a symbol color different from values collected before 1980. Behavior trends of secchi depth measurements collected after 1980 in all regions appear to be more consistent than data collected before 1980 . This could be because the average value is estimated from more observed data values for each summer period than the averages before 1980; consequently, years with limited data may show a wider variation from the previous or the next year. It is hard to tell from the figures if water clarity has decreased from the 1950 os to the present especially for the earlier years. If one ignores certain points, there has been degradation. However after 1980, there is a trend of slightly improved water clarity at segments CB1 and CB2 (Figure 35). This is in keeping with the hypothesis (Figure 38) that SAV's in the upper Bay are starting a comeback. 


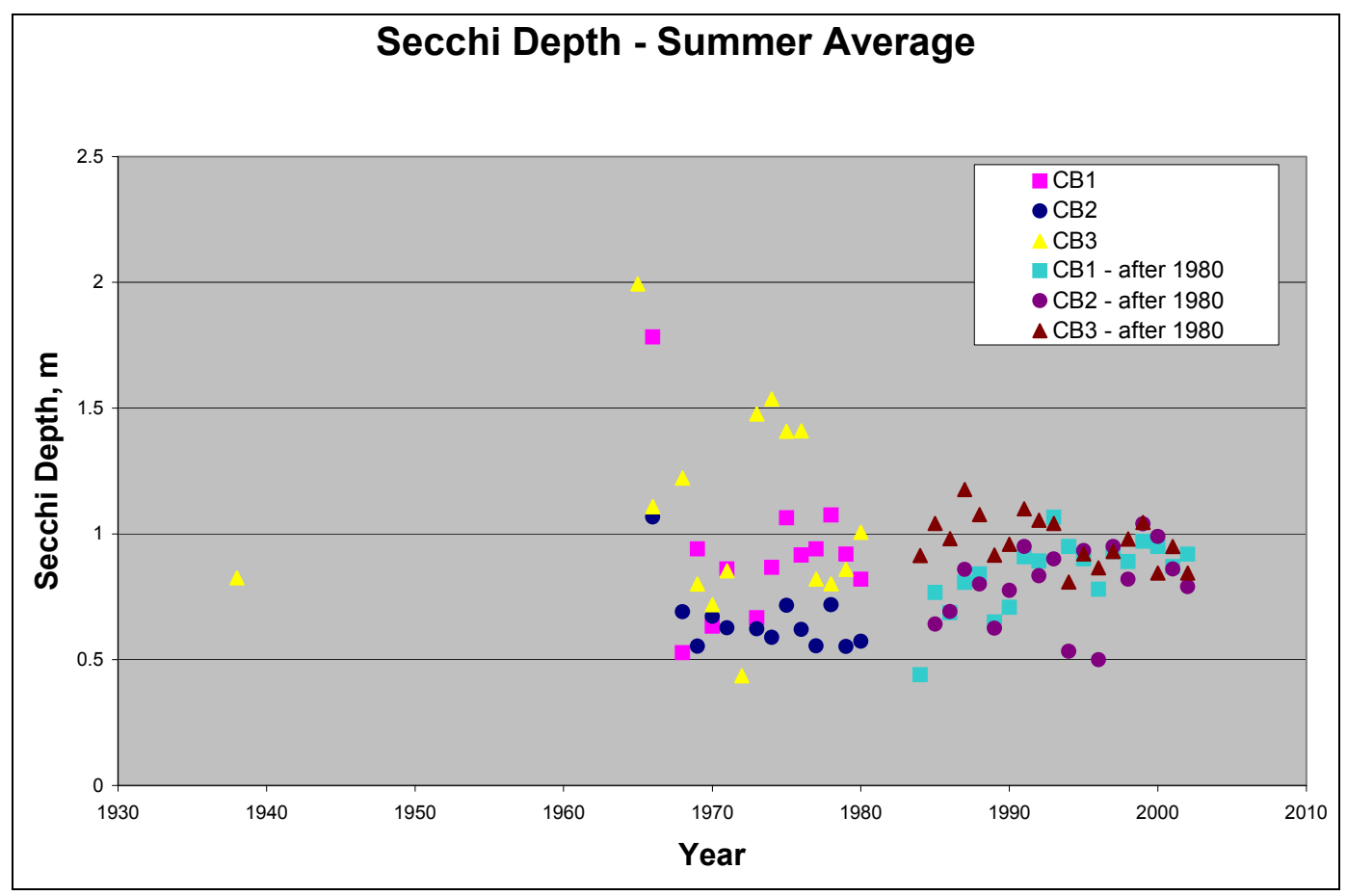

Figure 35. Secchi depth measurements in upper Chesapeake Bay region at segments $\mathrm{CB} 1, \mathrm{CB} 2$, and $\mathrm{CB} 3$.

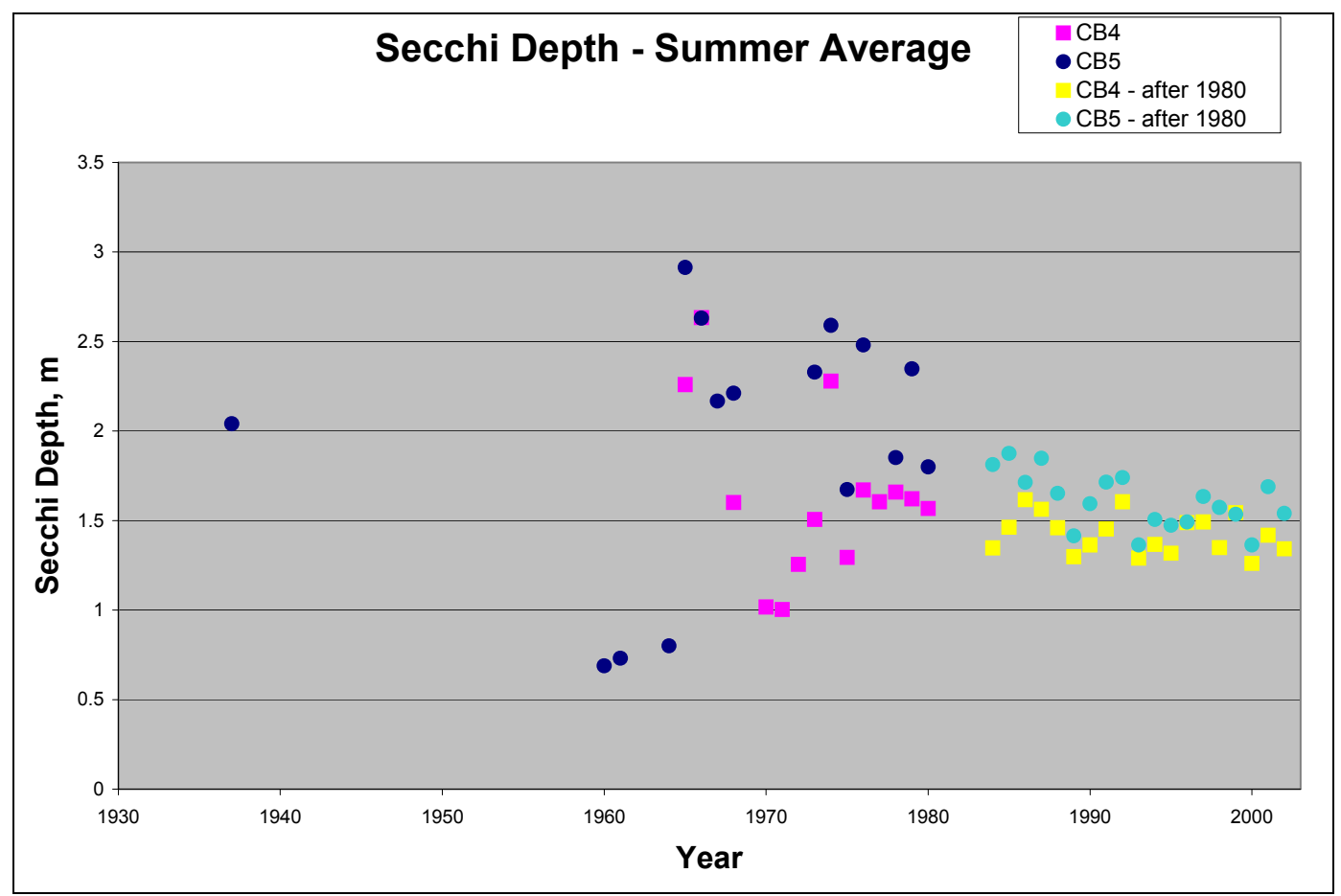

Figure 36. Secchi depth measurements in the mid Chesapeake Bay region at segments CB4, and CB5. 


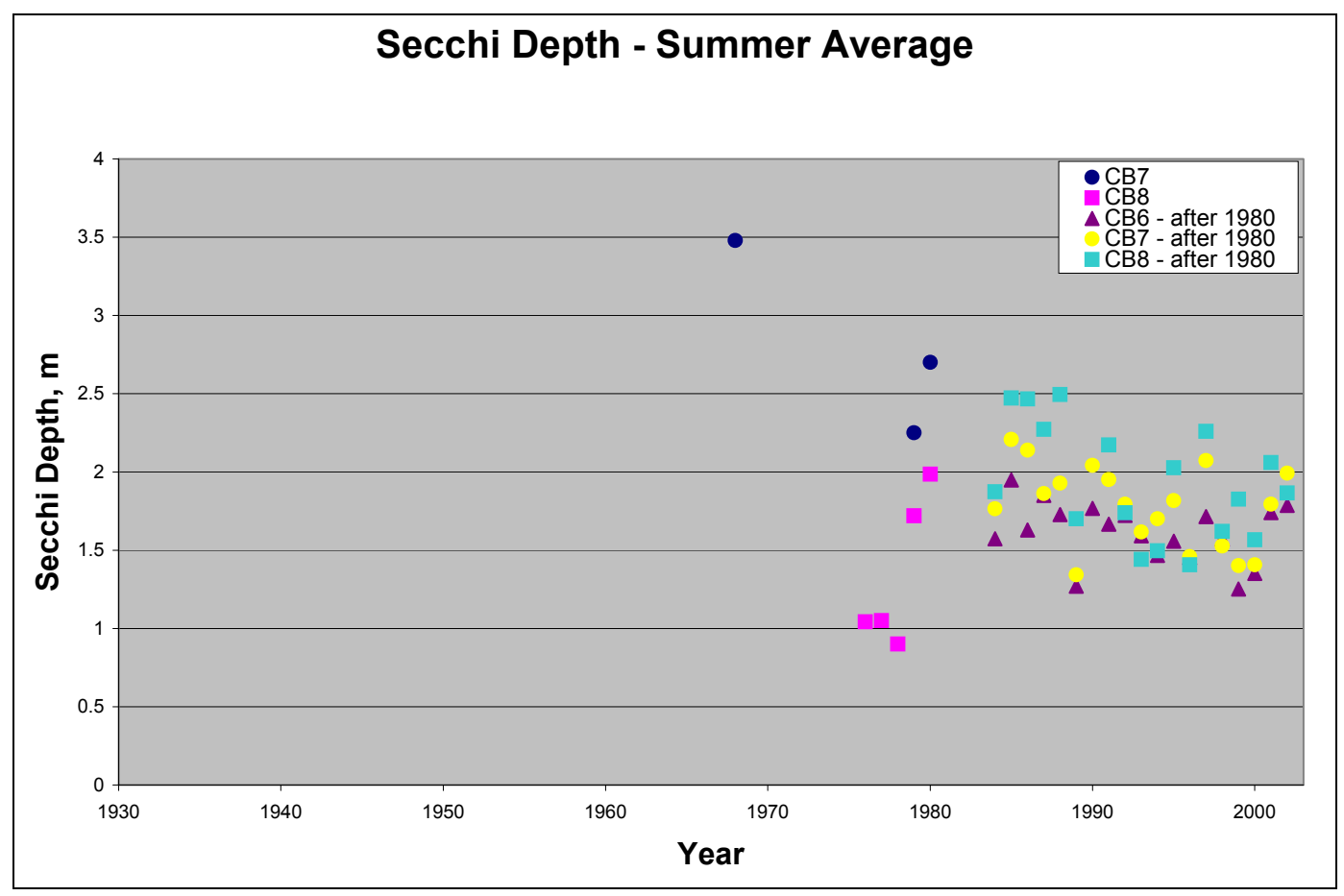

Figure 37. Secchi depth measurements in the lower Chesapeake Bay region at segments $\mathrm{CB} 6, \mathrm{CB} 7$ and CB8.

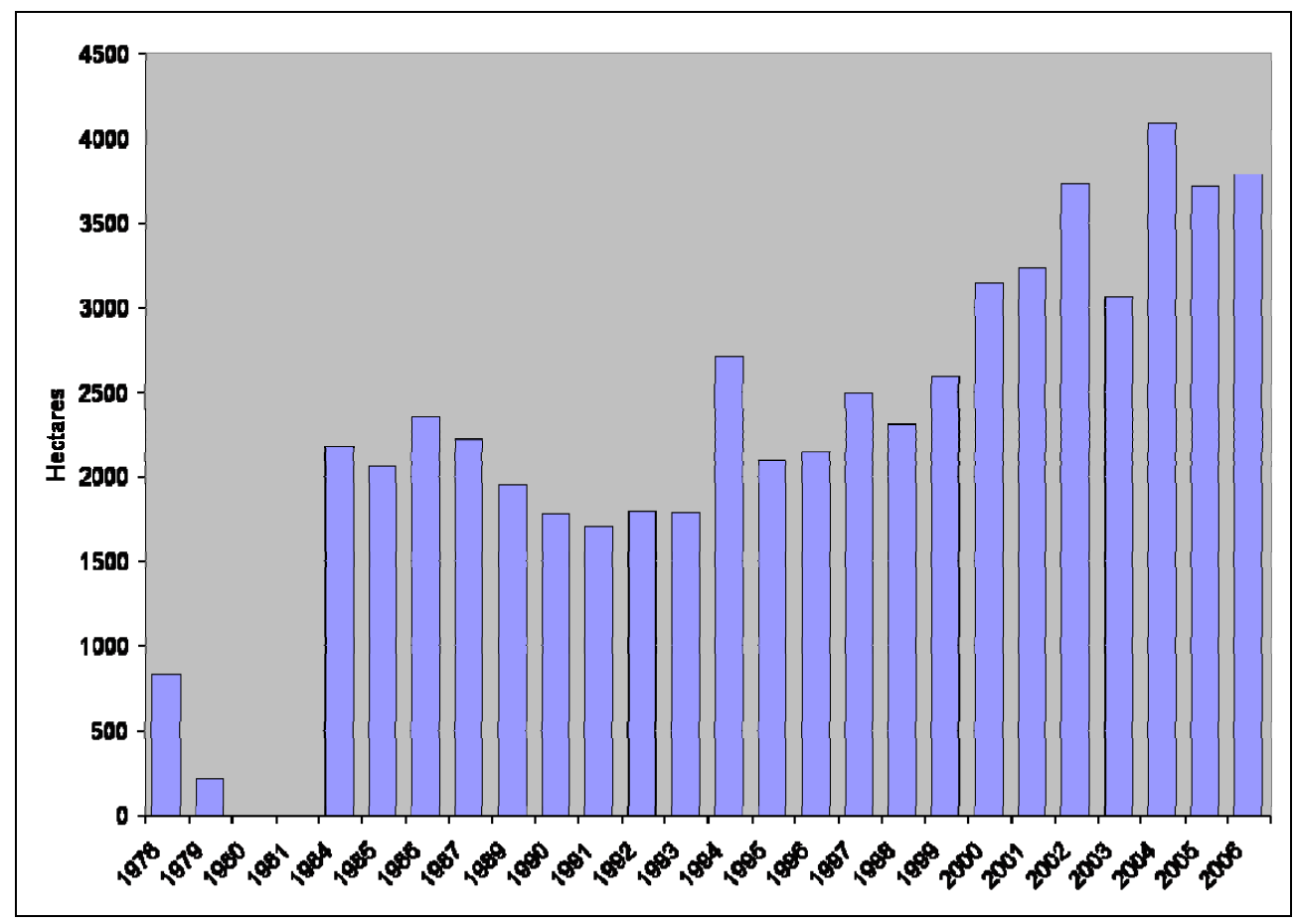

Figure 38. Hectares of submerged aquatic vegetation in Chesapeake Bay Program Segment CB1 1978-2006 (data courtesy of Dr. Ken Moore, Virginia Institute of Marine Science). 
At the other segments (Figures 36 and 37) there appear to be slight deceases in water clarity after 1980 . From these figures it can also be seen that as water moves from the uppermost regions of the bay to the ocean, water clarity improves.

\section{DO Volume Days}

Figures 32 through 34 show that of all the regions, the mid Bay was the most susceptible to anoxia during the summer months. It has almost twice as much water approaching anoxia (DO concentration $<1$ ) as the other two regions. All regions show the cyclic pattern of low DO in the summer with increasing DO concentrations in the fall.

Data from Hagy et al. (2004) for the July monthly average for years from 1950, 1952, 1957, and 1958 and 1985-1987 were compared to ICM output averaged over the same period. Differences in the data had to be overcome before comparisons were made. First, the anoxic data presented by Hagy was for the whole main stem of the Bay while the ICM data represented values for each of the three regions. To compensate for this, relative values were found by normalizing to the average of the combination of the $1950 \mathrm{O}$ and 1980's July monthly data for ICM output and Hagy's observed values. Before data could be normalized, ICM values were converted to the same units as Hagy's values (cubic meters). ICM values carried the units of cubic meters per day so they were divided by 30 days to get cubic meters. ICM 1980 's data were compared to 1950 os data and to Hagy's data to see if the same behavior patterns of anoxia followed the observations. Results are shown in Figures 39 and 40. Each figure contains three plots for the intervals of $\mathrm{DO} \leq 0.1, \mathrm{DO} \leq 1.0$, and $\mathrm{DO} \leq 2.0$ and the 1950s and 1980's data from ICM and Hagy, respectively. It should be pointed out that the lower interval from Hagy et al. (2004) was less than 0.2 as opposed to 0.1. In Figure 39, the values of 1-3 labeling the $x$-axis represent the years in the 1980 s and 1950 S DO volumes were modeled in ICM. Likewise in Figure 40, the values of 1-4 labeling the $x$-axis represent the years in the 1980 s (1985-1987) and 1950s (1950, 1952, 1957 and, 1958) from Table 3 in Hagy et al. (2004) DO volumes were available. From the figures, the amount of anoxic volume water for both Hagy and ICM for all intervals increased from the 1950s to the 1980's. Eutrophication has been blamed for increased anoxia in the Chesapeake Bay (Cooper and Brush 1993; Kemp et al. 2005; Burnett 1997) so by reducing the loads and light attenuation the amount of anoxia was reduced. Comparing the time series results (Figures 32-34) for base to the 1950s RMB2, the volume of anoxic 
water has increased from the 1950 O RMB2 conditions during the summer periods for all years as much as four times for the interval of 1.0 or less.

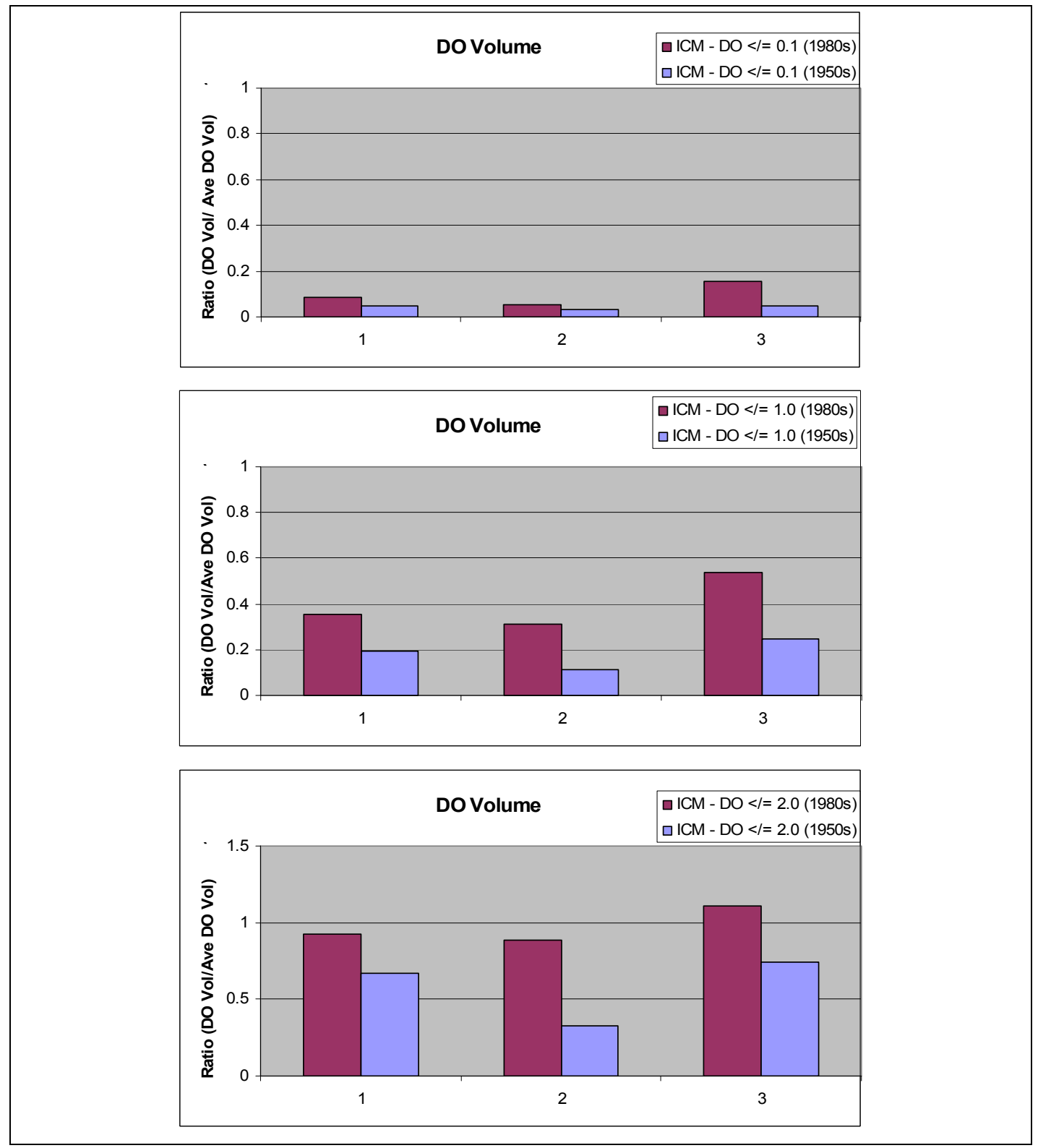

Figure 39. ICM normalized DO volume water at three intervals: upper - D0 $\leq 0.1$, middle $\mathrm{D} 0 \leq 1.0$, and lower - D0 $\leq 2.0$. 


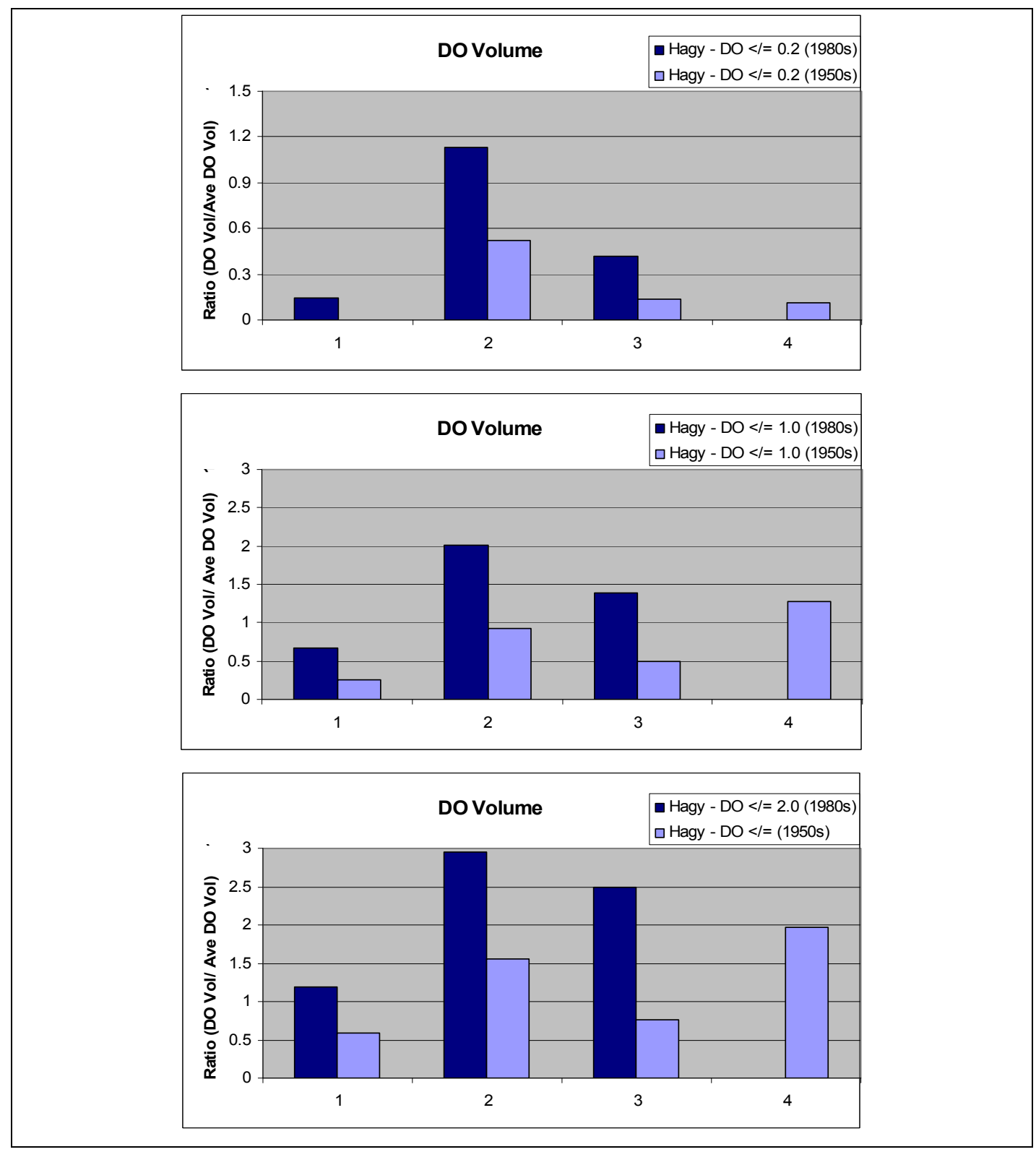

Figure 40. ICM normalized DO volume water at three intervals: upper - DO $\leq 0.1$, middle - DO $\leq 1.0$, and lower - DO $\leq 2.0$.

\section{Summary and conclusions}

Five simulations using the 2002 CBEM were conducted with analyses only discussed for the mid Bay. All model runs were simulated for the same time period, 1985 through 1994 , but only analyzed for the 1985 through 1987 period. These runs included:

- 2002 calibration run: base

- Sensitivity run 1: SR-1

- Sensitivity run 2: SR-2 
- 1950's restored mid Bay run 1: 1950's RMB1

- 1950's restored mid Bay run 2: 1950's RMB2

The biomass of phytoplankton for the 1950s RMB2 was reproduced by reducing the nutrient loads by $0.57 \mathrm{TN}$ and $0.703 \mathrm{TP}$ and light attenuation by half. These biomass values coincide with values reported by Harding and Perry (1997) for the chlorophyll $a$ concentrations of the 1950s and 1960s. Initially, halving the loads by themselves did not produce the desired effect on chlorophyll $a$; thus, light attenuation had to be reduced as well. Reduction of light attenuation was a way to represent clearer water in the mid Bay, which has been historically observed for the 1950-1960 period. Observed secchi depth data from the EPA Chesapeake Bay Program from the late 1930's to the present indicated decreased water clarity, especially after 1980 .

Patchiness was adjusted to allow SAV to grow in more of the cell where SAV beds exist. From this, the SAV biomass was slightly higher than the values estimated by Hagy (2004) and increased from the ICM base run. Biomasses of the benthic organisms could not be reproduced to the values used by Hagy but were increased for deposit feeders and decreased for suspension feeders. This was attributed to prey of deposit feeders increasing and prey of suspension feeders decreasing. All in all, biomass of the primary producers was very similar to the values Hagy set for the $1950 \mathrm{Os}$. Production rates $(\mathrm{P} / \mathrm{B})$ for most groups were increased or remained similar for the 1950s RMB2 run compared to the base run. The only groups that were adversely affected were the zooplankton groups. Reduced biomass and production for zooplankton are believed to stem from the fact that they are predators of phytoplankton and prey for the benthos. Consumption rates $(\mathrm{Q} / \mathrm{B})$ do not change much from the base except for the deposit feeders. They do vary greatly from values Hagy used for his 1950 os restored mid Bay Ecopath model. However, it can be noted that Hagy did not change the Q/B from values he used in his base run.

Time series of limitations plots on phytoplankton growth show that the SR-1 produces a co-limiting of $\mathrm{N}$ and $\mathrm{P}$ in the summer months and becomes $\mathrm{P}$ limiting the rest of the year. Adding reduced light attenuation causes the mid Bay to be dominated by $\mathrm{P}$ limiting conditions all year. For benthic algae and SAV, light is always the limiting factor for growth. This was shown for all scenarios run. SR-2 results show that with both loads and light attenuation reduced, $\mathrm{P}$ becomes more limiting throughout the 
year than before for benthic algae. However, there were no early observed data from the 1950s or 1960's to verify this. SAV limitation results for light show a cyclic pattern with less light limitation in the winter months, which probably coincide with the non-growing season. Again, there were no data to verify this.

DO concentrations follow similar behavior of chlorophyll $a$ in that there is variation seasonally. Concentrations increase in the spring with summer depletion in the upper and mid Bay. In the upper and mid Bay, longer periods of anoxia are observed more than anywhere else. The upper Bay has an anoxic period corresponding to the spring algae bloom that gets transported to the mid Bay. In the bottom waters for the 1950s RMB2 run, periods of anoxia are of shorter duration, which has historically been observed (Hagy et al. 2004; Kemp et al. 2005). Anoxic volume day plots also illustrate that the conditions of anoxic water from the 1950s RMB2 run have been reduced. For the interval of 1 or less, the 1950 os conditions of anoxia have been reduced about four times less than in modern times. Comparing to DO anoxic volume from Hagy et al. (2004), ICM does produce the behavior of DO anoxia increasing from the 1950s to the 1980s.

Overall, ICM produced reasonable results for conditions that could have occurred in the 1950s. Although observed data were scarce from the $1950 \mathrm{OS}$ or 1960 s to make comparisons, the results follow behavior described in literature by other researchers. These runs demonstrate the ability of ICM to reasonably predict past or future conditions/ behavior of a system if the appropriate boundary conditions are known. As demonstrated, primary producer information from ICM combined with an already available Ecopath model can be a useful tool to answer critical questions about management strategies. As changes occur in the environment (manmade or naturally), a coupled ICM /Ecopath tool can be useful in considering consequences to the upper and lower trophic levels in the ecosystem. 


\section{References}

Adolf, J. E., C. L. Yeager, W. D. Miller, M. E. Malone, and L.C. Harding, Jr. 2006. Environmental forcing of phytoplankton floral composition, biomass, and primary productivity in Chesapeake Bay, USA. Estuarine, Coastal and Shelf Science 67 (2006): 108-122.

Batiuk, R. A., R. J. Orth, K. A. Moore, W. C. Dennison, J. C. Stevenson, L. Staver, V. Carter, N. Rybicki, R. E. Hickman, S. Kollar, S. Bieber, P. Heasly, and P. Ergstrom. 1992. Chesapeake Bay submerged aquatic vegetation habitat requirements and restoration goals: A technical synthesis. CBP/TRS 83/92. Annapolis, MD: USEPA, Chesapeake Bay Program.

Bayley, S., V. D. Stotts, P. R. Springer, and J. Stennis, 1978. Changes in submerged aquatic macrophyte populations at the head of Chesapeake Bay, 1958-1975. Estuaries 1: 73-84.

Boynton, W. R., J. H. Garber, R. Summers, and W. M. Kemp. 1995. Inputs, transformations and transport of nitrogen and phosphorus in Chesapeake Bay and selected tributaries. Estuaries 18: 285-314.

Bratton, J. F., S. M. Colman, and R. R. Seal, II. 2003. Eutrophication and carbon sources in Chesapeake Bay over the last 2700 yr: human impacts in context. Geochimica et Cosmochimica Acta 67(18):3385-3402.

Breitburg, D. L. 2002. Effects of hypoxia and the balance between hypoxia and enrichment, on coastal fishers and fisheries. Estuaries 25:767-781.

Brush, G. S. 1989. Rates and patterns of estuarine sediment accumulation. Limnology and Oceanography 34:1235-1246.

Brush, G. S., F.W. Davis, and S. Rumer. 1980. Biostratigraphy of Chesapeake Bay and its tributaries: A feasibility study. Final Rep. to the U.S. Environmental Protection Agency, Grant No. R205962. Baltimore, MD: The Johns Hopkins University.

Burnett, L. E. 1997. The challenges of living in hypoxic and hypercapnic aquatic environments. Amer. Zool. 37:633-640.

Carter, V., and N. B. Rybicki. 1986. Resurgence of submersed aquatic macrophytes in the tidal Potomac River, Maryland, Virginia and the District of Columbia. Estuaries 9:368-375.

.1990. Light attenuation and submersed macrophyte distribution in the tidal Potomac River and estuary. Estuaries 13:441-452.

Cerco, C., and T. Cole. 1994. Three-dimensional eutrophication model of Chesapeake Bay. Technical Report EL-94-4. Vicksburg, MS: U.S. Army Engineer Waterways Experiment Station.

Cerco, C., and M. Meyers. 200o. Tributary refinements to the Chesapeake Bay model. Journal of Environmental Engineering 126(2):164-174. 
Cerco, C., and M. Noel. 2004. The 2002 Chesapeake Bay eutrophication model. EPA 903-R-04-004. Annapolis, MD: Chesapeake Bay Program Office, U.S. Environmental Protection Agency.

Cerco, C., and D. Tillman. 2008. Use of coupled eutrophication and network models for examination of fisheries and eutrophication processes. ERDC/EL TR-0810. Vicksburg, MS: U.S. Army Engineer Research and Development Center.

Cerco, C., D. Tillman, and T., Gerald. 2008. Users' guide to linking the CE-QUAL-ICM and Ecopath Models. ERDC/EL SR-xxxx. Vicksburg, MS: U.S. Army Engineer Research and Development Center.

Cerco, C. F. 1995. Response of Chesapeake Bay to nutrient load reduction. Journal of Environmental Engineering 121(8):549-557.

Christensen, V., and D. Pauly. 1992. ECOPATH II - A software for balancing steady-state ecosystem models and calculating network characteristics. Ecological Modelling 61: 169-185.

Christensen, V., C. Walters, and D. Pauly. 2000. Ecopath with Ecosim: A user's guide. Fisheries Centre, University of British Columbia.

Conley, D. J., and T. C. Malone. 1992. The annual cycle of dissolved silicate in Chesapeake Bay: Implications for the production and fate of phytoplankton biomass: Marine Ecology Progress Series v. 81: 121-128.

Cooper, S. R., and G. S. Brush. 1991. Long-term history of Chesapeake Bay anoxia. Science 254: 992-996. .1993. A 2500-year history of anoxia and eutrophication in Chesapeake Bay. Estuaries 16: 617-626.

Cronin, W. B., and D. W. Pritchard. 1975. Additional statistics on the dimensions of the Chesapeake Bay and its tributaries: Cross-sectional widths and segment volumes per meter depth. Ches, Bay Inst. Spec. Rep. 42.

Dauer, D. M., S. B. Weisberg, and J. A. Ranasinghe. 2000. Relationships between benthic community condition, water quality, sediment quality, nutrient loads, and land use patterns in Chesapeake Bay. Estuaries 23: 80-96.

Davis, F. D. 1985. Historical changes in submerged macrophyte communities of upper Chesapeake Bay. Ecology 66(3): 981-993.

Dennison, W. C., R. J. Orth, K. A. Moore, J. C. Stevenson, V. Carters, S. Kollarp, P.W. Bergstrom, and R. Batiuk. 1993. Assessing water quality with submersed aquatic vegetation. Bioscience 43:86-94.

DiToro, D., and J. Fitzpatrick. 1993. Chesapeake Bay sediment flux model. Contract Report EL-93-2. Vicksburg, MS: U.S. Army Engineer Waterways Experiment Station, Environmental Laboratory.

Dortch, M., R. Chapman, and S. Abt. 1992. Application of three dimensional Lagrangian residual transport. Journal of Hydraulic Engineering 118:831-848. 
Fisher, T. R., L. W. Harding, D. W. Stanley, and L. G. Ward. 1988. Phytoplankton, nutrients, and turbidity in the Chesapeake, Delaware, and Hudson estuaries. Estuar. Coast. Shelf Sci. 27:61-93.

Gerritsen, J, A. F. Holland, and D. E. Irvine. 1994. Suspension-feeding bivalves and the fate of primary production: an estuarine model applied to Chesapeake Bay. Estuaries 17:403-416.

Hagy, J.D. III. 2002. Eutrophication, hypoxia and trophic transfer efficiency in Chesapeake Bay. PhD., University of Maryland, College Park.

Hagy, J. D., W. R. Boyton, C. W. Keefe, and K. V. Wood. 2004. Hypoxia in Chesapeake Bay, 1950-2001: Long-term change in relation to nutrient loading and river flow. Estuaries 27:634-658.

Harding, L.W. 1994. Long-term trends in the distribution of phytoplankton in Chesapeake Bay: roles of light, nutrients, and stream flow. Marine Ecology Progress Series 104:267-291.

Harding, L. W., Jr., and E. Perry. 1997. Long-term increase of phytoplankton biomass in Chesapeake Bay. Mar. Ecol. Prog. Ser.157:39-52.

Harding, L. W., Jr., M.E. Mallonee, and E. Perry. 2002. Toward a predictive understanding of primary productivity in a temperate, partially stratified estuary. Estuarine Coastal Shelf Sci. 55: 437-463.

Heinle, D. R. 1966. Production of a calanoid copepod, Acartia tonsa, in the Patuxent River estuary. Chesapeake Sci. 7: 59-74.

Herman, P. M. J., J. J. Middleburg, J. Van De Koppel, and C. H. R. Heip. 1999. Ecology and estuarine macrobenthos. Adv Ecol Res 29:195-240.

Holland, A. F., A. T. Shaughnessy, and M. H. Hiegel. 1987. Long-term variation in mesohaline Chesapeake Bay macrobenthos: Spatial and temporal patterns. Estuaries 10:227-245.

Jaworski, N. A., P. M. Groppman, A. A. Keller, and J. C. Prager. 1992. A watershed nitrogen and phosphorus balance: The Upper Potomac River Basin. Estuaries 15:83-95.

Johnson, B., K. Kim, R. Heath, B. Hsieh, and L. Butler. 1993. Validation of a three dimensional hydrodynamic model of Chesapeake Bay. Journal of Hydraulic Engineering 199(1): 2-20.

Kemp, W. M., R. R. Twilley, J. C. Stevenson, W. R. Boynton, and J. C. Means. 1983. The decline of submerged vascular plants in upper Chesapeake Bay: Summary of results concerning possible causes. Mar Technol Soc J 17: 78-89.

Kemp, W. M., P. A. Sampou, J. Garber, J. Tuttle, and W. R. Boynton. 1992. Seasonal depletion of oxygen from bottom waters of Chesapeake Bay: Roles of benthic and planktonic respiration and physical exchange processes. Marine Ecology Progress Series 85:137-152. 
Kemp, W. M., W. R. Boynton, J. E. Adolf, D. F. Boesch, W. C. Boicourt, G. Brush, J. C. Cornwell, T. R. Fisher, P. M. Glibert, J. D. Hagy, L. C. Harding, E. D. Houde, D. G. Kimmel, W. C. Miller, R. I. E. Newell, M. R. Roman, E. M. Smith, and J. C. Stevenson. 2005. Eutrophication of Chesapeake Bay: Historical trends and ecological interactions. Marine Ecology Progress Series 303: 1-29.

MacIntyre, H. L., R. J. Geider, and R. M. McKay. 1996. Photosynthesis and regulation of Rubisco activity in net phytoplankton from Delaware Bay. J. Phycol. 32:718-731.

Malone, T. C., L. H. Crocker, S. E. Pike, and B. Wendler. 1988. Influences of river flow on the dynamics of phytoplankton production in a partially stratified estuary. Mar. Ecol. Prog.Ser. 48: 235-249.

Malone, T. C., H. W. Ducklow, E. R. Peele, and S. E. Pike. 1991. Picoplankton carbon flux in Chesapeake Bay. Mar. Ecol. Prog. Ser 78: 11-22.

Marshall, H. G., and R. V. Lacouture. 1986. Seasonal patterns of growth and composition for phytoplankton in the lower Chesapeake Bay. Estuarine, Coastal and Shelf Science 23:115-130.

Marshall, H. G. 1994. Chesapeake Bay phytoplankton: I. Composition. Proceedings of the Biological Society of Washington. 107:573-585.

Nielsen, S. L., K. Sand-Jensen, J. Borum, and O. Geertz-Hansen. 2002. Phytoplankton, nutrients, and transparency in Danish coastal waters. Estuaries 25:930-937.

Officer, C. B., R. B. Biggs, J. L. Taft, L. E. Cronin, M. A. Tyler, and W. R. Boynton. 1984. Chesapeake Bay anoxia: Origin, development, and significance.

Science 223:22-27.

Orth, R. J., and K. A. Moore. 1983. Chesapeake Bay: An unprecedented decline in submersed aquatic vegetation. Science 222(5):1-53.

Orth, R. J., and K. A. Moore. 1984. Distribution and abundance of submerged aquatic vegetation in Chesapeake Bay: An historical perspective. Estuaries 7:531-540.

Orth, R. J., and K. A. Moore. 1986. Seasonal and year-to-year variations in the growth of Zostera marina L. (eelgrass) in lower Chesapeake Bay. Aquat. Bot. 24:335-341.

Paerl, H. W., L. M. Valdes, and B. L. Peierls. 2006. Anthropogenic and climatic influences on the eutrophication of large estuarine ecosystems. Limnol. Oceanogr. 51(1, Part 2), 2006:448-462.

Paul, R. W. 2001. Geographical signature of middle Atlantic estuaries: Historical layers. Estuaries 24:151-166.

Scavia, D., and S. B. Bricker. 2006. Coastal eutrophication assessment in the United States. Biogeochemistry 79:187-208.

Scavia, D., E. M. A. Kelly, and J. D. Hagy. 2006. A simple model for forecasting the effects of nitrogen loads on Chesapeake Bah Hypoxia. Estuaries and Coasts. 29(4):674-684. 
Sellner, K. G. and D. C. Brownlee. 1988. Phytoplankton and microzooplankton component data summary. Baltimore, MD: Maryland Department of the Environment, Chesapeake Bay Water Quality Monitoring Program.

Taft, J. L., W. R. Taylor, E. O. Hartwig, R. Loftus. 1980. Seasonal oxygen depletion in Chesapeake Bay. Estuaries 3:242-247.

Tillman, D., C. Cerco, and M. Noel. 2006. Conceptual processes for linking eutrophication and network models. TN-SWWRP-09-05. Vicksburg MS: U.S. Army Engineer Research and Development Center.

Twilley, R. R., and J. W. Barko. 1990. The growth of submerged macrophytes under experimental salinity and light conditions. Estuaries 13(3): 311-321.

U.S. Environmental Protection Agency(USEPA). 1983. Chesapeake Bay: A profile of environmental change. Washington DC: Unites States Environmental Protection Agency.

Verity, F. G. 1988. The trophic structure of pelagic communities: Hypothesis and problems. In Perspectives on the Chesapeake Bay: Recent advances in estuarine science. Ed. M.F. Lynch and E.C. Krone, 34-56. Chesapeake Research Consortium.

Zimmerman, A. R., and E. A. Canuel. 2002. Sediment geochemical records of eutrophication in the mesohaline Chesapeake Bay: Limnology and Oceanography 47:1084-1093. 


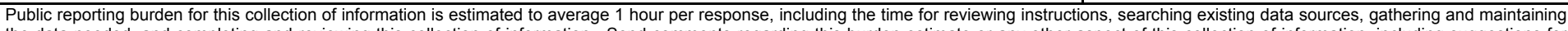

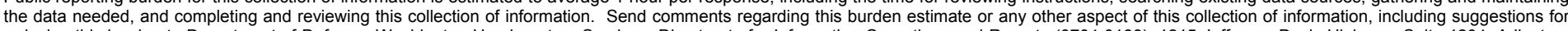

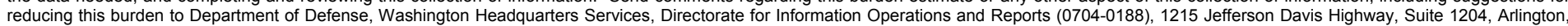

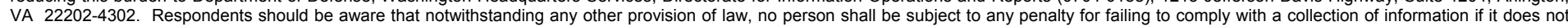
display a currently valid OMB control number. PLEASE DO NOT RETURN YOUR FORM TO THE ABOVE ADDRESS.
1. REPORT DATE (DD-MM-YYYY)
2. REPORT TYPE
3. DATES COVERED (From - To)

August 2009

Final report

\section{TITLE AND SUBTITLE}

Recreating the 1950's Chesapeake Bay: Use of a Network Model to Guide the

Application of a Eutrophication Model

5a. CONTRACT NUMBER

5b. GRANT NUMBER

5c. PROGRAM ELEMENT NUMBER

\section{AUTHOR(S)}

Dorothy H. Tillman and Carl F. Cerco

5d. PROJECT NUMBER

5e. TASK NUMBER

5f. WORK UNIT NUMBER

\section{PERFORMING ORGANIZATION NAME(S) AND ADDRESS(ES)}

8. PERFORMING ORGANIZATION REPORT NUMBER

U.S. Army Engineer Research and Development Center

Environmental Laboratory

ERDC/EL TR-09-9

3909 Halls Ferry Road

Vicksburg, MS 39180-6199

9. SPONSORING / MONITORING AGENCY NAME(S) AND ADDRESS(ES)

10. SPONSOR/MONITOR'S ACRONYM(S)

U.S. Army Corps of Engineers

Washington, DC 20314-1000

11. SPONSOR/MONITOR'S REPORT NUMBER(S)

\section{DISTRIBUTION / AVAILABILITY STATEMENT}

Approved for public release; distribution is unlimited.

\section{SUPPLEMENTARY NOTES}

\section{ABSTRACT}

This report is the last of a series that documents research relating the coupling of spatially and temporally detailed eutrophication models with ecosystem models that lack spatial and temporal resolution. Specifically, the Corps of Engineers Integrated Compartment Water Quality Model, CE-QUAL-ICM (ICM) is coupled to the Ecopath with Ecosim (EWE) fisheries model. This research examines the feasibility of restoring the ecosystem that existed in the 1950s mid Bay based on current knowledge of the driving forces of overabundance of nutrients and decreased water clarity. Making adjustments to loads and coefficients controlling eutrophication through a numerical water quality model is one way to study this problem. Five simulations using the 2002 CBEM were conducted with analyses only discussed for the mid Bay. All model runs were simulated for the same time period, 1985 through 1994, but only analyzed for the 1985 through 1987 period. ICM produced reasonable results for conditions that could have occurred in the 1950s. Although observed data were scarce from the 1950s or 1960's to make comparisons, the results follow behavior described in literature by other researchers. These runs demonstrate the ability of ICM to reasonably predict past or future conditions of a system.

\section{SUBJECT TERMS}

CE-QUAL-ICM model

Chesapeake Bay

16. SECURITY CLASSIFICATION OF:

\begin{tabular}{|l|l|}
\hline a. REPORT & b. ABSTRACT \\
UNCLASSIFIED & UNCLASSIFIED
\end{tabular}

Ecosystem models Eutrophication models

c. THIS PAGE
UNCLASSIFIED

17. LIMITATION OF ABSTRACT
EWE fisheries model

Numerical models

Water quality models

\begin{tabular}{c|l}
$\begin{array}{c}\text { 18. NUMBER } \\
\text { OF PAGES }\end{array}$ & $\begin{array}{l}\text { 19a. NAME OF RESPONSIBLE } \\
\text { PERSON }\end{array}$ \\
\cline { 2 - 2 } 78 & $\begin{array}{l}\text { 19b. TELEPHONE NUMBER (include } \\
\text { area code) }\end{array}$ \\
&
\end{tabular}

